\title{
Is the ZIKV Congenital Syndrome and Microcephaly Due to Syndemism with Latent Virus Coinfection?
}

\author{
Solène Grayo
}

check for updates

Citation: Grayo, S. Is the ZIKV

Congenital Syndrome and

Microcephaly Due to Syndemism with Latent Virus Coinfection? Viruses 2021, 13, 669. https:// doi.org/10.3390/v13040669

Academic Editor:

Luis Martinez-Sobrido

Received: 11 February 2021

Accepted: 10 April 2021

Published: 13 April 2021

Publisher's Note: MDPI stays neutral with regard to jurisdictional claims in published maps and institutional affiliations.

Copyright: (C) 2021 by the author. Licensee MDPI, Basel, Switzerland. This article is an open access article distributed under the terms and conditions of the Creative Commons Attribution (CC BY) license (https:// creativecommons.org/licenses/by/ $4.0 /)$.
Institut Pasteur de Guinée, BP 4416 Conakry, Guinea; solene.grayo.ext@pasteur.fr or grayo.solene@orange.fr

\begin{abstract}
The emergence of the Zika virus (ZIKV) mirrors its evolutionary nature and, thus, its ability to grow in diversity or complexity (i.e., related to genome, host response, environment changes, tropism, and pathogenicity), leading to it recently joining the circle of closed congenital pathogens. The causal relation of ZIKV to microcephaly is still a much-debated issue. The identification of outbreak foci being in certain endemic urban areas characterized by a high-density population emphasizes that mixed infections might spearhead the recent appearance of a wide range of diseases that were initially attributed to ZIKV. Globally, such coinfections may have both positive and negative effects on viral replication, tropism, host response, and the viral genome. In other words, the possibility of coinfection may necessitate revisiting what is considered to be known regarding the pathogenesis and epidemiology of ZIKV diseases. ZIKV viral coinfections are already being reported with other arboviruses (e.g., chikungunya virus (CHIKV) and dengue virus (DENV)) as well as congenital pathogens (e.g., human immunodeficiency virus (HIV) and cytomegalovirus (HCMV)). However, descriptions of human latent viruses and their impacts on ZIKV disease outcomes in hosts are currently lacking. This review proposes to select some interesting human latent viruses (i.e., herpes simplex virus 2 (HSV-2), Epstein-Barr virus (EBV), human herpesvirus 6 (HHV-6), human parvovirus B19 (B19V), and human papillomavirus (HPV)), whose virological features and co-exposition with ZIKV may provide evidence of the syndemism process, shedding some light on the emergence of the ZIKV-induced global congenital syndrome in South America.
\end{abstract}

Keywords: Zika virus; latent virus; coinfection; reactivation; coevolution; tropism; transmission; viral reservoir; persistence; congenital syndrome

\section{Introduction}

\subsection{The Emergence of Congenital ZIKV Syndrome (CZS)}

A strange silent period of almost seven years (2007-2015) elapsed between the emergence of the Zika virus (ZIKV) in Oceania, defined by an increased incidence in the classical form of the illness, i.e., "Zika fever" (Yap in 2007: 49 confirmed cases and 39 probable cases), and the South American outbreak (Brazil in 2015: 440,000-1,500,000 reported cases), where the virus marked its re-emergence in powerful and serious forms with atypical clinical manifestations in humans, and shading the French Polynesian outbreak two years before (French Polynesia in 2013: 294 confirmed cases and approximately 8000-19,000 suspected cases) [1-6].

As the incidence of neonatal microcephaly increased 20-fold in April/November 2015 compared to the rate in 2010-2014 (CDC, 2017) during the ZIKV outbreak (based on epidemiological studies and reported cases), in-depth investigations are on the rise in an attempt to characterize the detailed features of ZIKV infection in pregnancy and provide evidence of a causal link between maternal ZIKV infection and the recent emergence of specific congenital symptoms [7-12]. These data highlight the ability of ZIKV to replicate and disseminate in different fetal organs (e.g., the spleen, lungs, liver, muscle, and brain), supporting the mechanism affecting the embryo and/or fetus development [13-18]. The widespread use of various imagery tools, computed tomography (CT), and magnetic resonance imaging (MRI) indicates the importance of non-classical neuroimaging 
findings (e.g., fetal microcephaly and intracranial calcifications) in Congenital Syndrome (CS) definition(s) [18-24]. The evidence has been rapidly piling up and strengthens the relationship between ZIKV infection and microcephaly, which has been well summarized in numerous reviews [25-28]. In light of global public health being in a state of high tension, this evidence has led to the declaration of ZIKV as a new congenital pathogen with potential risk of vertical transmission and association with specific fetal effects (such as microcephaly), referred to as CZS (e.g., in Brazil's PAHO commitment (Pan American Health Organization), the World Health Organization's 2015 report (WHO), and the WHO's 2016 statement). Unfortunately, this sudden attention might result in skews (both quantitative and qualitative) in the form of overestimating the number of ZIKV congenital infections and, also, by attributing an overly strong correlation between ZIKV and observed congenital manifestations influenced by confounding factors [29,30]. By glossing over other alternative determinants, ZIKV is credited as the causal agent of microcephaly as a result of outbreaks and/or its occurrence in endemic areas, while gaps in knowledge still remain [31-34]. In fact, microcephaly is the most common birth defect-related indicator of suspected congenital ZIKV infection with microcalcifications, which gives rise to two issues. First, no consensus regarding a standard definition of microcephaly has yet been established (i.e., no uniformity exists in its definition) $[35,36]$. Second, microcephaly is a common feature of several congenital viruses (e.g., human cytomegalovirus (HCMV), herpes simplex virus (HSV), human immunodeficiency virus (HIV), and rubella virus); it could be caused by exposure to toxics (e.g., drugs, alcohol, and other environmental substances and it has already been described in several congenital genetic defects. [37-39]). Thus, at first glance, the description of CZS shows no specific findings compared to other etiologies, in particular, congenital viral infections [40].

In the context of its emergence in South America and the impressive phenotype of microcephaly, this can sometimes lead to speculation and, even, to blind acceptance [41,42]. Even if viral RNA isolation in fetal and placental tissues (e.g., brain) may be related to a possible specific tropism regarding ZIKV, this would provide evidence of a correlation, but is not enough to determine whether ZIKV actually causes microcephaly or brain damage [41-44]. In some cases, the connection of ZIKV to fetal brain abnormalities is established without confirmation via a positive ZIKV test [45], and there is the risk that other arboviruses that co-circulate in similar spatiotemporal contexts are a confounding factor [46-48]. In the general thinking of a clinical syndrome as the result of one (single) pathogen isolated from clinical specimens, the detection of other contributing agents is omitted and/or not prioritized in the context of an outbreak [49].

In fact, features of the Brazilian CZS outbreak have become a talking point in relation to the local high concentration of microcephaly cases in northeastern Brazil [50-54]. Campos et al. proposed that "the unusual distribution of microcephaly in the Northeast region might be accentuated by prior, sequential exposition and/or co-viral infection with other pathogen", suggesting that ZIKV is not the only culprit [55-58].

\subsection{Current ZIKV Pathogenesis Image: Mirror of Common Congenital Syndrome?}

Even though the Aedes aegypti vector is competent at promoting efficient ZIKV infection of humans in urban areas, viral transmission through human biofluids brings the classification of ZIKV closer to the human pathogens group (1) (human reservoir and "vector") than to the arboviruses group (e.g., dengue virus (DENV), chikungunya virus (CHIKV), or yellow fever virus (YFV)) $[59,60]$. The increasing frequency of microcephaly in ZIKVinfected mothers during the early stage of pregnancy reinforces the hypothesis that ZIKV promotes particular tropism (2) in the fetal-placental unit (the neuronal sphere) and that it belongs to the group of congenital pathogens in humans, called the TORCH group (Toxoplasma gondii, other pathogens, rubella, cytomegalovirus, herpes simplex virus) [61-64]. The viral persistence (3) in the female urogenital tract (vaginal secretions, endocervical mucosa, ovary, endometrium, and uterus) means ZIKV is far from having disclosed all of its pathogenesis potential (4) in the reproductive life of women [65-67], especially in 
the context of following particular pregnancy-induced reactivation from genital and/or other ZIKV reservoirs [68-70]. The description of CZS from case reports and experimental studies provides a "new image" of contemporary ZIKV with the collapse of the "dead host/reservoir host" boundaries in humans. This view differs from that of the Yap outbreak, which was marked (in the first instance) by ZIKV emergence resulting from a long-term dynamic process occurring in four steps: exposition, infection, spread, and adaptation (Figure 1) [4,71-73]. The American outbreak shows the complexity of the ZIKV evolution system following a similar baseline model to the emergence of ZIKV in Yap (Figure 1) by the growing complicated use of determinants. This serves as evidence of a continued risk given ZIKV's capacity to re-emerge under various environmental conditions originating from new ecological models designed bases on biological mechanism networks $[74,75]$ (Figure 1). In this paper, regarding the phenotypic observation, four specific featural changes are outlined for human infections during the last ZIKV outbreak: (1) transmission mode (ex: vertical transmission), (2) tissue tropism (ex: neuronal sphere)), (3) persistence (ex: genital organ), and/or (4) pathogenesis (ex: teratogenic).

- Virus-host compatibility

- Pathogen host range

- Species barrier

- Nucleotide substitution

- Recombination/reassortment

- Selection

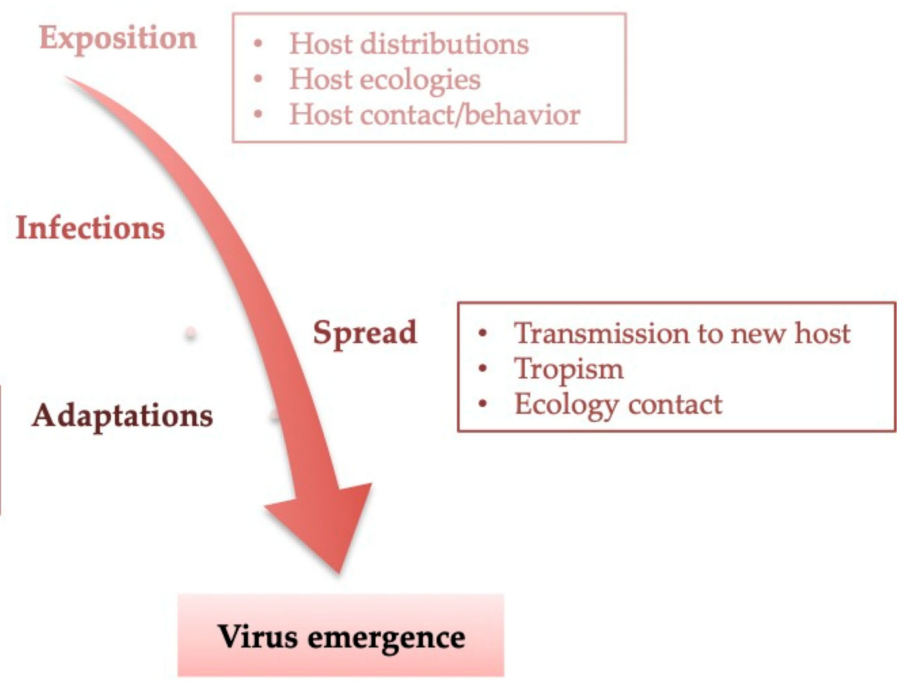

Figure 1. Dynamic process of viral emergence following four steps: exposition, infection, spread, and adaptation. At each step, several biological mechanisms and/or determinants in rectangles can be involved and can result in changes to the viral genome, host tropism, and pathogenicity, providing a baseline for the definition of viral evolution (based on data from Parrish [72], Woolhouse [75], and Ketkar [71]).

The new potential acquisition may come from singular viral adaptation in hosts as well as interactions with other pathogens that possess these skills $[58,76]$. The mixed microbial nature of human infections has been recognized since the early 1920s and is heterogenous in global populations [77]. Simultaneous infection of the host by two viruses or more is an important discovery in terms of human health. Although it may well prove to be doubleedged, the net results of co-viral infection on human health are mostly disadvantageous (Figure 2) [49]. The clustering of two or more infectious diseases, leading to synergistic or antagonistic relationships that enhance or aggravate diseases or that have negative global health effects on populations living in some environments, is referred to as syndemics (or the syndemism concept) [78-80].

Environmental parameters are an important aspect in the emergence of infectious disease outbreaks (Figure 2) [81]. In addition to affecting the life cycle of pathogens and the ecology of vectors, climate also drives socioeconomic factors (e.g., income and education) and environmental management (e.g., building structures, street cleansing, water supply and its storage, and solid waste collection) (Figure 2) [82-84]. Certain cases are more susceptible to contracting one or more infectious diseases, which could completely recast the view of the ZIKV system in cases of interactions with other pathogens [85]. ZIKV can learn, be trained, and acquire numerous functions resulting from its contact with 
other viruses, which can be cooperative, competitive (e.g., interference), or synergistic interactions (e.g., accommodation) [49,86]. ZIKV and other viruses can encounter one another within an organism at different levels and at different periods of ZIKV illness (e.g., phases of incubation, symptomaticity (viremia), chronicity, and/or persistence) (Figure 2), resulting in changes to the classical definition of ZIKV syndrome in terms of kinetics and disease progression, as well as to complications and also phenotype changes that mirror the tissue tropism effects related to ZIKV (Figure 2) [87-89].

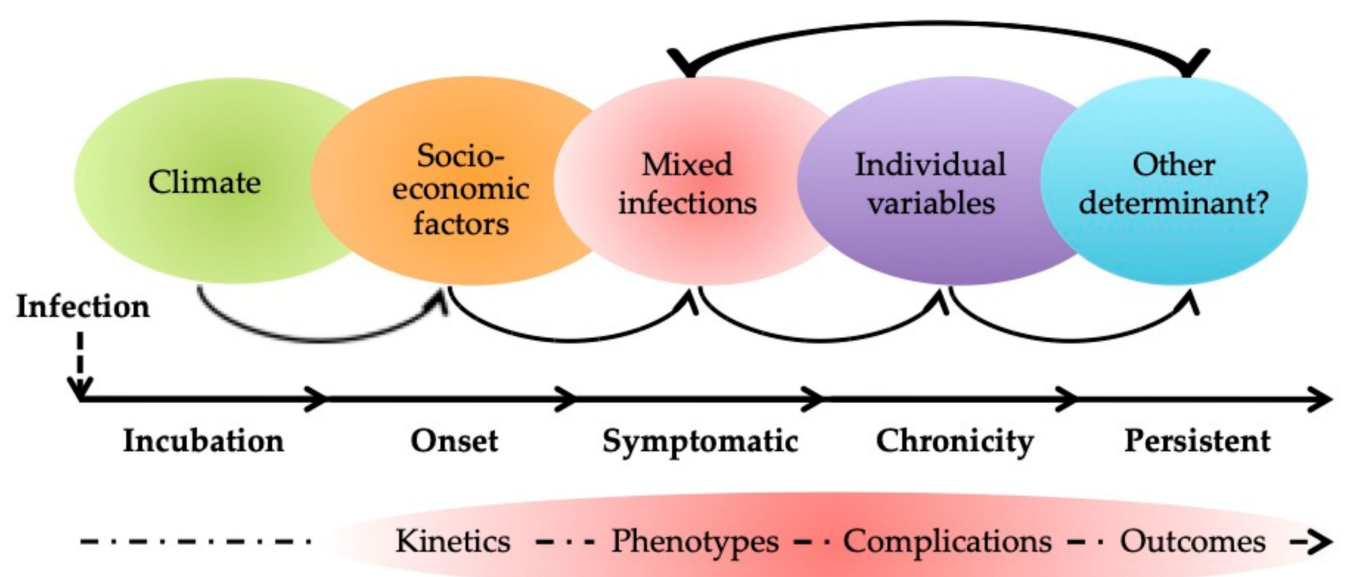

Figure 2. Mixed infections (MIs) influence ZIKV disease in a human host. Once past the incubation phase, ZIKV infection (black straight arrows) may progress along four steps: onset, symptomatic, chronic, and persistent. To simplify, the black straight arrows are here arbitrarily of equal size, but the duration of the steps depends on various conjugated factors. The climate (green circle), socio-economic factors (orange circle), mixed infections (red circle), individual variables (purple circle), and other determinants (unknown) (blue circle) participate in the ZIKV emergence and physiopathology. Each of them interacts with others (round black arrows). The climate promotes the mosquito bites opportunities leading to ZIKV infection in human and the incubation period (first arrow). The climate and the socio-economic factors affect the health status of person and the probability to develop an infection with the onset period (second arrow). The mixed infections (MIs) characteristics (ex: pathogenic composition) depend on the climate and socio-economic factors (round black arrows) and define the ZIKV physio-pathogenicity with the symptomatic period (third arrow). The individual variables, such genetic predisposition, drive the host response, from the clearing infection to the chronic period (fourth arrows). Conjugated with four prior factors (round black arrows), other determinants may make ZIKV persistent in the host (fifth arrows). Depending on composition changes, MIs can partially or totally recast the ZIKV infection characteristics in individual host, influencing the kinetic of the infection, the phenotype, the complications, and the outcome (red oval).

Prior to defining the nature of co-viral evolution in humans and which benefits provide the co-exposition of ZIKV pathogenicity in pregnancy, the question is: Does the current context meet the conditions set forth for co-viral infection/ZIKV opportunities? Currently, are all conditions set for promoting co-viral infection/ZIKV opportunities? If deemed appropriate, which kinds of coinfections are emerging?

\subsection{Coinfection Opportunities beyond Arbovirus during the Brazil Outbreak: Human Latent Virus (HLV)}

Despite in-depth research, the mechanism by which ZIKV infection causes microcephaly remains a worrying and mysterious puzzle [90-95]. More so than the lack of available in vivo models, ZIKV is a biological complex system whose evolution design depends on the meeting of other biological entities, such as through the occurrence of a mixed viral infection in human. Taken together, this leads to the belief that globalization contributes to the intensification of co-exposition, leading to great opportunities for ZIKV outbreaks (Figures 1 and 3 for ZIKV, latent virus and host) [56-58,96]. ZIKV is an arthropod-borne virus, transmitted especially by Aedes species. Evidence of other modes of transmission have also been discovered, such as sexual transmission. These two possible modes of transmission result in mosquitos and humans both being drivers of spatiotempo- 
ral ZIKV repartition and dissemination $[59,60]$. The intense co-circulation of arboviruses and their vectors in endemic areas mean that some countries and cities are more involved in coinfection events between ZIKV, arboviruses, and congenital pathogens [39,52,97-102]. Areas with particularly dense and heterogenous populations have a higher frequency of and diversity in multiple types of infections (Figures 2 and 3) [103,104]. With the high population density, economic and financial challenges promote the flow of both information and people. These intensive exchanges and activities take place in short periods of time and are concentrated in limited spaces. The differences in urbanism from one region to another, or between continents, may determine the exact epicenter zone of ZIKV appearance, and these determinants differ between Africa and America [105,106]. Today, and with the lack of an emerging infectious disease surveillance system, some regions still seem unaffected by ZIKV re-emergence (i.e., cases are underreported) [87,107,108].

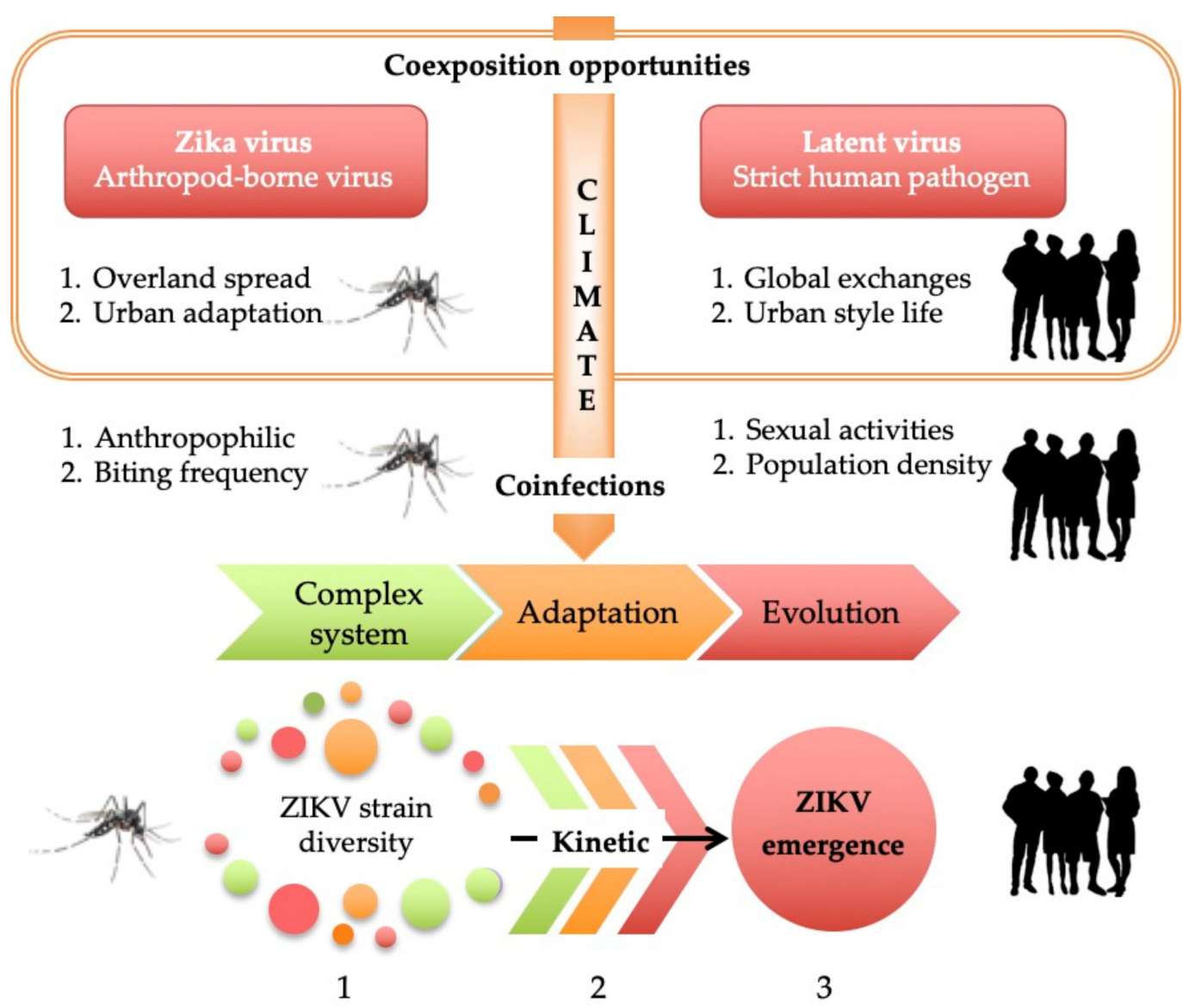

Figure 3. HLV/ZIKV co-exposition to human and co-infection in human to promote ZIKV emergence. Upper panel: two factors promote the HLV / ZIKV co-exposition opportunities to human; (1) the hosts similar distribution (vector and human) due to the global spreading of the mosquito vector (ZIKV host) and the intensification of human exchanges (HLV host); (2) the common preference to urban environment due to the vector adaptation capacity and the human lifestyle change. Middle panel: two factors promote the HLV/ZIKV coinfections in human; (1) the specific hosts (vector and human) behavior with vector anthropophilic and human sexual activities; (2) the contact frequency between hosts (vector and human) through mosquito bites in high density populations. Lower panel: while the climate influences the three biological systems (viruses, vector, and human), HLVs infection may increase the strains diversity of mosquito borne ZIKV in human leading to following sequential process; (1) the adaptation kinetics, (2) leading to ZIKV selection and emergence, (3) with new physio-pathogenicity features.

The particular relationship between Aedes aegypti and urban humans creates opportunistic environments for both co-viral exposition and coinfection from similar or distinct infection routes (Figure 3) [109-111]. The city life promotes opportunities related 
to human behaviors for ZIKV infection and coinfections via other modes of transmission $[59,60,112,113]$. For example, the multiple routes of ZIKV infection (e.g., transfusion blood, sexual transmission, and mosquito bites) increases not only the incidence of ZIKV infectious diseases but also the broad occurrence of co-viral infections with arboviruses and sexual and human persistent viruses (Figure 3) [39,52,97-101]. In urban areas, the opportunities for human-human viral infection and to become a carrier of a pool of viruses in their latency period are important from the perspective of intimate contact between two asymptomatic persons [114-116].

Humans are a reservoir of the most of persistent viruses resulting from area and/or sex transmission with genital and/or neurotropism and can be reactivated [114-116]. In parallel to the behavioral evolution of Aedes aegypti, characteristics of human life, such as socioeconomic status and sexual habits, particularly influence the coinfection opportunities in adulthood during the reproductive stage. As a consequence, the abundance and the types of microorganisms within humans change over time and according to the place of residence, and this process continues to shape the immune profile.

As such, it would appear rational to claim that mixed infections are the norm in urban/endemic areas, making some populations more susceptible [117,118]. In contrast, proposing low socioeconomic status as the true contributing factor to greater infectious disease exposition would mask a complex reality with unbalanced access to sanitary care, education, and population behaviors [84,119-121]. The urban organization of its habitats is based on socioeconomic determinants, resulting in health problems originating in deprived clusters of social groups. [84,122]. In some areas, certain populations, such as woman and infants, are more vulnerable and are at greater risk of contracting, both early and frequently, latent infection diseases as well as to being exposed to arboviruses, thus mirroring the CZS epicenter area [123-125].

Mirroring the syndemism concept, the coinfection arising from initial persistent infection, reactivated by superinfection from another pathogen, such as ZIKV, needs to be investigated, even if it is challenging. In the literature, the "celebrities" HCMV and HIV receive the most attention in relation to congenital persistent viruses in pregnancy [100,126-129]. Nevertheless, the latent virus group also includes some viruses of the herpes family, such as herpes simplex virus 2 (HSV-2), Epstein-Barr virus (EBV), human herpesvirus 6 (HHV-6), and other pathogens such as human parvovirus B19 (B19V) and human papillomavirus (HPV), which are detected in the female genital tract (FGT) (e.g., the vagina and cervix, endometrial cavity, uterus, and ovaries) (Tables 1-3) [39,52,97-101]. All of them affect the FGT and are all public health concerns due the reactivation potential and lytic cycle triggering, which impacts on the reproductive life of women, well-being during childbearing, and oncogenic risks to women's health (e.g., cervical carcinoma) as well as on pregnancy outcomes and infant susceptibility to later diseases [130]. If sharing similar clinical, biological, and mechanistic features, the "meeting" between ZIKV and a latent virus is a concern for human health. 


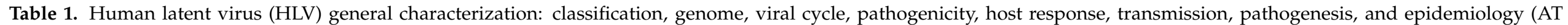
(aero-pharyngeal transmission), VT (Vertical Transmission), IC (Intia Contact)).

\begin{tabular}{|c|c|c|c|c|c|c|}
\hline Items & Species & HSV-2 & HHV-6 & EBV & PB19 & HPV \\
\hline \multirow{3}{*}{ Name } & Family & & Herpesviridae & & Parvoviridae & Papillomaviridae \\
\hline & Subfamily & Alphaherpesvirinae & Betaherpesvirinae & Gammaherpesvirinae & Parvovirinae & \\
\hline & Genre & Simplex virus & Simplex virus & Lymphocryptovirus & Erythroparvovirus & Alphapapillomavirus \\
\hline \multirow{3}{*}{ Genome } & Nature & dsDNA & dsDNA & dsDNA & ssDNA & dsDNA \\
\hline & Form & Linear & Linear & Linear & Circular & Circular \\
\hline & Size & $120-180 \mathrm{~kb}$ & $140-240 \mathrm{~kb}$ & $180 \mathrm{~kb}$ & $4-6 \mathrm{~kb}$ & $8 \mathrm{~kb}$ \\
\hline \multirow{3}{*}{ Viral cycle } & Cell types & Epithelial & TCD4 cell & Memory B cell & Erythroid precursor & Mucosa epithelium \\
\hline & Transcription & Nucleus & Nucleus & Nucleus & Nucleus & Nucleus \\
\hline & Replication kinetic & Short (hours) & Long (days) & Latency dominance & Short (hours) & Short (hours) \\
\hline \multirow{3}{*}{ Pathogenicity } & Tissue tropism & Genital tract (GT) & Ubiquitous & Ubiquitous & Bone marrow, fetal liver & \multirow{3}{*}{$\begin{array}{l}\text { Mouth, thorax, GT } \\
\alpha 6 \beta 4 \text { integrin } \\
\text { Malignancy } \\
\text { (abnormal cell growth and } \\
\text { differentiation) }\end{array}$} \\
\hline & Receptor & TAM family & CD46? & PDL-1/PD-1 & Globoside, $\alpha 5 \beta 1$ integrin & \\
\hline & Cell effects & Pro-inflammation, apoptosis & Immunomodulation, apoptosis & $\begin{array}{l}\text { Tumorgenesis } \\
\text { (B-cell immortalization) }\end{array}$ & $\begin{array}{l}\text { Erythropoiesis blockage (red } \\
\text { blood cell precursors death) }\end{array}$ & \\
\hline Host response & Immune response & $\begin{array}{l}\text { Inflammation (IL-1b, IL-8), } \\
\text { inflammasome activation } \\
\text { (NLRP3) }\end{array}$ & $\begin{array}{l}\text { Cell specificity } \\
\text { immunomodulation }\end{array}$ & $\begin{array}{l}\text { Anti-apoptosis, antiviral immune } \\
\text { control, genome instability }\end{array}$ & $\begin{array}{l}\text { Inflammation (IL-2, IL-6,) and } \\
\text { anti-apoptosis } \\
\text { (NF-kB) }\end{array}$ & $\begin{array}{l}\text { Th2 dominance and } \\
\text { prolonged response } \\
\text { (IL-5, IL-10, IL-17A) }\end{array}$ \\
\hline Transmission & Mode & IC, VT, perinatal & AT, saliva, VT & AT, saliva & $\begin{array}{l}\text { AT, saliva } \\
\text { Hematological, } \\
\text { immunological state }\end{array}$ & IC \\
\hline \multirow{3}{*}{ Pathogenesis } & Primo-infection & $\begin{array}{l}\text { Genital lesions (warts), } 24 \% \\
\text { symptomatic }\end{array}$ & $\begin{array}{l}\text { HHV-6B: Roseola infantum or } \\
\text { 6th disease }\end{array}$ & Mononucleosis-like syndrome & \multirow{3}{*}{$\begin{array}{l}\text { Slapped cheek syndrom } \\
\text { 5th disease } \\
\text { Cardio-, hepato-, } \\
\text { neuro-pathies } \\
\text { Immunologic \& } \\
\text { hematologic disorders }\end{array}$} & \multirow{3}{*}{$\begin{array}{l}\text { Genital warts resolving within } \\
2 \text { years } \\
\text { Cervical cancer } 70 \% \text { : } \\
\text { HPV16/18 subtypes } \\
\text { Reproductive life woman, } \\
\text { immuno-depressive person }\end{array}$} \\
\hline & Progression & Latency $(20 \%-50 \%)$ & Latency $(70 \%-100 \%)$ & $\begin{array}{l}\text { Nasopharyngeal carci- noma, } \\
\text { lymphoma, }\end{array}$ & & \\
\hline & Vulnerable person & Reproductive life woman & $\begin{array}{l}\text { Toddlers } \\
\text { ( } 2-3 \text { years of age) }\end{array}$ & Immuno-depressive person & & \\
\hline Epidemiology & Key point & $\begin{array}{l}\text { (+) } 11.3 \% \text { of global } \\
\text { seroprevalence }\end{array}$ & (+) $90 \%$ of the toddlers & (+) $90 \%$ of the global population & $\begin{array}{l}(+) \text { mostly of the school } \\
\text { ages children }\end{array}$ & $100 \%$ of cervical cancer origin \\
\hline
\end{tabular}


Table 2. Viral latency features: sites of latency, viral forms, mechanisms of establishment, and maintenance.

\begin{tabular}{|c|c|c|c|c|c|c|}
\hline Items & Species & HSV-2 & HHV-6 & EBV & PB19 & HPV \\
\hline Non-infectious reactivation & Factors & $\begin{array}{l}\text { Environnemental stressors } \\
\text { (UV exposition, hypoxia, } \\
\text { trauma, pain), hormonal } \\
\text { treatment, } \\
\text { immunosuppression state, } \\
\text { or «spontaneous» }\end{array}$ & Pregnancy? & $\begin{array}{l}\text { Environnemental stressors } \\
\text { (UV exposition, hypoxia), } \\
\text { hormonal treatment, } \\
\text { immunosuppression state }\end{array}$ & Oxygen, stress, Pregnancy & $\begin{array}{l}\text { Environmental stressors } \\
\text { (UV exposition, hypoxia), } \\
\text { smoking, hormonal } \\
\text { treatment, pregnancy, } \\
\text { genital wart }\end{array}$ \\
\hline & Virus triggers & HIV, HPV & EBV, CMV & HIV & Unknown & EBV, HSV-2, HHV-6, PB19 \\
\hline $\begin{array}{l}\text { Pathogen-induced reactivation } \\
\text { and consequences }\end{array}$ & Consequences & $\begin{array}{l}\text { HIV sexual transmission, } \\
\text { HPV-related cervical cancer }\end{array}$ & $\begin{array}{l}\text { EBV and CMV antibodies } \\
\text { production, CMV } \\
\text { lymphopenia aggravation }\end{array}$ & $\begin{array}{l}\text { B-cell immortalization, } \\
\text { anti-apoptotic signalization, } \\
\text { tumorgenesis }\end{array}$ & 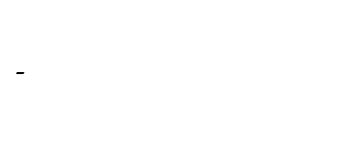 & $\begin{array}{l}\text { HPV genomic instability } \\
\text { (EBV), HPV oncogenesis } \\
\text { (HSV-2), HPV clearance } \\
\text { inhibition (HHV-6) }\end{array}$ \\
\hline \multirow{3}{*}{$\begin{array}{l}\text { Pregnancy induced } \\
\text { reactivation (woman } \\
\text { pre-conceptual) }\end{array}$} & Context & Recurrent genital herpes & HHV6-A variant & \multirow{3}{*}{$\begin{array}{l}35 \% \text { of reactivation related to } \\
\text { HIV coinfection } \\
\text { ? } \\
\text { Placental cells changes, Th2 } \\
\text { predominance at } \\
\text { placental interface }\end{array}$} & \multirow{3}{*}{$\begin{array}{l}\text { 13-20 weeks pregnancy } \\
\text { (fetal oxygen demand) } \\
\text { VT } \\
\text { Hypoxia-induced } \\
\text { inflammation and fetal } \\
\text { abnormal development }\end{array}$} & $\begin{array}{l}\text { Genital warts (mostly } \\
\text { asymptomatic) }\end{array}$ \\
\hline & Consequences & ST and VT & $1 \%$ of $\mathrm{VT}$ & & & VT and PT \\
\hline & Pregnancy outcome & $\begin{array}{l}\text { Abortion, low birth weight, } \\
\text { premature delivery }\end{array}$ & $\begin{array}{l}\text { Infertility, miscarriage, } \\
\text { embryogenesis affect }\end{array}$ & & & $\begin{array}{l}\text { Infertility, abortion, } \\
\text { choriocarcinoma }\end{array}$ \\
\hline
\end{tabular}


Table 3. Human latent virus (HLV) reactivation, ZIKV infection, and pregnancy: factors for reactivation, pathogen-induced reactivation, and pregnancy-induced reactivation.

\begin{tabular}{|c|c|c|c|c|c|c|}
\hline Items & Species & HSV-2 & HHV-6 & EBV & PB19 & HPV \\
\hline \multirow[t]{2}{*}{ Latency sites } & Cell types & Neuronal cells & CD34+HSCs & Memory B cells & Erythroid progenitor cells & $\begin{array}{l}\text { Epithelial cells (basal stem } \\
\text { cells) }\end{array}$ \\
\hline & Tissues tropism & Sensory nerves & $\begin{array}{l}\text { Lymphoid organs (e.g. } \\
\text { spleen), lymph nodes) }\end{array}$ & $\begin{array}{l}\text { Salivary glands, lymphoid } \\
\text { organs }\end{array}$ & $\begin{array}{l}\text { Unspecific tissues (e.g. skin, } \\
\text { liver, synovial membrane) }\end{array}$ & $\begin{array}{l}\text { Skin (epidermis), Genital } \\
\text { tract (cervix), oral cavity } \\
\text { (salivary glands, tonsillar } \\
\text { crypts) }\end{array}$ \\
\hline \multirow{3}{*}{ Latency forms } & Viral DNA form & Circular episome & Proviral form & Circular, episome & Proviral form & Circular episome \\
\hline & Cell DNA link & & Integrated & Linked & Integrated & Linked \\
\hline & Localization & Nucleus & Nucleus & Nucleus & Nucleus & Nucleus \\
\hline \multirow{3}{*}{ Latency establishment } & $\begin{array}{l}\text { Viral DNA-host } \\
\text { DNA relation }\end{array}$ & $\begin{array}{l}\text { HSV-2 DNA "chromatin } \\
\text { form" and independent }\end{array}$ & \multirow{3}{*}{$\begin{array}{l}\text { Viral genome as a integral } \\
\text { part of host chromosome } \\
\text { Synchronic duplication } \\
\text { (S phase) } \\
\text { Telomeric junction } \\
\text { area integration }\end{array}$} & \multirow{3}{*}{$\begin{array}{l}\text { Host DNA binding via } \\
\text { specific structurally region } \\
\text { Synchronic duplication } \\
\text { (S phase) } \\
\text { Chromosomally } \\
\text { tethered virus }\end{array}$} & $\begin{array}{l}\text { Viral genome as a integral } \\
\text { part of host chromosome }\end{array}$ & $\begin{array}{l}\text { Host DNA binding via } \\
\text { specific structurally region }\end{array}$ \\
\hline & Host cell cycle & Only in non-dividing cells & & & $\mathrm{S}$ and $\mathrm{G} 2 / \mathrm{M}$ phases arrest & $\mathrm{S}$ phase quiescent \\
\hline & Viral genome keys & & & & $\begin{array}{l}\text { Palindromic repeat } \\
\text { sequences }\end{array}$ & $\begin{array}{l}\text { Chromosomally } \\
\text { tethered virus }\end{array}$ \\
\hline \multirow[b]{2}{*}{ Latency maintain } & Principe & Limited viral transcription & Limited viral transcription & $\begin{array}{l}\text { Survival immortalization } \\
\text { infected B cells }\end{array}$ & \multirow{2}{*}{$\begin{array}{l}\text { Down-regulated erythroid } \\
\text { cell cycle } \\
\text { DNA replicative machinery } \\
\text { using and DDR disturbing } \\
\text { Hypoxia, NS1, } \\
\text { EPO/EPO rcp. }\end{array}$} & \multirow{2}{*}{$\begin{array}{l}\text { Non-cyclic cells growth and } \\
\text { tumorgenesis } \\
\text { DNA replicative machinery } \\
\text { using and DDR disturbing } \\
\text { HPV6/7 activators, } \\
\text { HPV2 replication }\end{array}$} \\
\hline & Regulation & Epigenetic process & Epigenetic process & Epigenetic process & & \\
\hline
\end{tabular}


Considering this, the following section reviews the characteristics of the above-listed latent virus biological systems to highlight the key elements of balancing the latency/lytic phase and of triggering the lytic cycle regarding the effects in pregnancy and/or similarities with the ZIKV biological system. In other words, whether common or specific to each virus, latent virus pathogenic mechanisms and their overlap with some of those observed in CZS and others atypical clinical manifestations (Guillain-Barré Syndrome (GBS)) may be evidence of ZIKV's membership in the latent virus group or, at least, may be an influencing partner (a triggering factor) in the development of later diseases related to latent virus. Figure A1 lists various latent pathogen-related definitions to facilitate reading.

\section{Human Latent Virus (HLV) Selection with Common Interests in CZS}

\subsection{Herpesviridae: $H S V-2, H H V-6$, and $E B V$}

Herpesviridae is a family of enveloped viruses with large and linear double-stranded DNA genomes and with three subfamilies, namely, Alpha-, Beta-, and Gammaherpesvirinae. In view of its ubiquity, this group is a global public health concern, affecting human populations at all stages of life (i.e., birth, puberty, reproductive life, and old age) and influencing infant susceptibility in later years following silent in utero transmission [114,131]. The members of the herpes simplex family are transmitted by various biofluids (HLV, Table 1) and persist in the host's body throughout their life, causing recurrent infections, particularly via latent processes, unlike slow infections and chronic infections (Figure A2).

Each subfamily shows specificities in tissue tropism and in targeted cells as a latent reservoir and/or in performing active replication, which is more or less lytic and characterizes the pathogenicity level (HLV, Table 2). The mechanisms of establishing latency and the reactivation need to be independently discussed, including the trigger factors of reactivation. As a consequence, each subfamily of herpesviruses is examined from one selected referent: HSV-2 (A), HHV-6 (B), and EBV (G) to the Alpha-, Beta-, and Gammaherpesvirinae subfamilies, respectively. Particular attention is paid to their frequent underestimation in pregnancy compared to HCMV and varicella-zoster virus (VZV), and to their causing of congenital syndromes close to CZS.

\subsubsection{Herpes Simplex Virus 2 (HSV-2): Female Genital Herpes}

HSV-2/1 belongs to the Alphaherpesvirinae subfamily, as does VZV. HSV-1/2 replicates with typically short cycles (hours) in epithelial cells and establishes viral latency in sensory neurons $[114,132]$. HSV-2 herpes genitalis is the most common sexually transmitted infection (STI) [133] (Table 1). The global HSV-2 prevalence is estimated as $11.3 \%$, with a higher rate in Africa (31\%) followed by the United States (14\%) [134,135]. HSV-2 antibody detection is more frequent in women than men. The level of sexual activity and the number of sexual partners are major risk factors for HSV-2 exposition [136-140]. Primary infection is more often associated with clinical evidence, commonly painful genital lesions. In one study, $24 \%$ of patients showed systemic symptoms, such as fever, headaches, and malaise [133]. Typically, 10-14 days post-exposition, alphaherpesvirus latency is established within the cell body's nucleus of sensory nerves (e.g., cervical, lumbosacral, or autonomic ganglia) [141].

- Latent genome persistence of alphaherpesviruses

HSV-2 adopts a circular form of viral DNA, called the episome. As per non-dividing cells, this episomal plasmid is not attached to the host's DNA, but still adopts cell chromatin DNA-like structures (Table 2) [114].

- Latent genome expression and maintenance

In HSV latency, transcription is almost completely silenced via mostly epigenetic regulation of modulating chromatin forms, its accessibility, and the expression of chromatin assembly factors from the expression of specific viral proteins that interact with chromatin regulation factors $[114,142,143]$. The latency-associated transcripts (LATs) code from the long repeat region of the viral genome, which participates in latent infection by 
antisense regulation to repress expression, promoting repressive chromatin forms (heterochromatin) and showing anti-apoptosis action [114]. The LATs could also be assisted by host- and viral-encoded miRNAs as well as by host DNA methylation in the latency control $[114,132,142,143]$. Short noncoding RNAs along with long noncoding RNAs (lncRNAs) are LAT transcripts typically involved in the maintenance of latency $[114,142,143]$. Nevertheless, not all infected latency cells express LATs, and some studies support the function of LATs in reactivation or, at least, in establishing a high risk of spontaneous reactivation [141]. The expression of lytic transcripts in latency is favorable for reactivation events rather than silent states, heightening the susceptibility to triggering factors (Table 2).

- Reactivation

Reactivation of HSV-2, which is resident in sensory neurons that innervate the reproductive tract and dermatome, is related to various types of stress (e.g., clinical interventions, pain, heat, or UV light-induced, emotional changes) and the hormonal treatment of disorders (e.g., glucocorticoid and corticoid) (Table 2) [139,144]. Contrary to past beliefs, the viral reactivation risks of asymptomatic infection are as likely as those that have been clinically evidenced [144]. Recurrent infections may occur all along the reproductive life span; the female mucosal urogenital tract epithelium is more prone to asymptomatic shedding than men's genital skin [144], especially in pregnancy [138,141]. Pregnancy-induced HSV-2 reactivation provides an opportunity for mother-to-fetus silent transmission, possibly associated with congenital HSV-2 infection (Table 3) $[145,146]$.

- Pregnancy

While in the female urogenital tract the bacterial flora protects against HSV-2-induced vaginosis and inflammation, some findings indicate a reverse effect in pregnancy, with polymicrobial infections benefitting HSV-2 pathogenicity, resulting in fatal fetal outcomes (e.g., spontaneous abortion, low birth weight, and premature delivery) [147]. In response to bacterial lipopolysaccharide (LPS), HSV-2-infected human fetal membrane explants show changes in Tyro3, Axl, and Mer (TAM) receptor expression and in the modulation of innate immune responses (interleukin -1 (IL-1)) [147]. The in vivo model results confirm HSV-2 coinfection-induced inflammation (ILb-1 production) and inflammasome (NLRP3 expression). The HSV-2 reactivation from superinfection by other sexually transmitted pathogens, such as HIV or HPV, may also unbalance the microbiota in the Female Genital Tract (FGT), favoring bacterial vaginosis (BV) and thus enhancing the pathogenicity of HSV-2 [135,148-150]. HSV-2 reactivation, in turn, may predispose the FGT to HIV primoinfection by facilitating the inflammatory infiltration of CD4-positive T lymphocyte cells in the FGT [141]. In Rio de Janeiro, Brazil, one investigation showed a high frequency of HHV-2/HIV coinfection in patients with recurrent and primary genital infections [149,151]. The consequences of HSV-2/HIV coinfection and with other viral STI infections are of particular concern in pregnancy. Moreover, a cofactor effect of HSV-2 coinfection in HPV pathogenesis is also reported in experimental and epidemiological studies, associated with a higher risk of developing HPV cervical cancer [148].

- ZIKV/HSV-2 coinfections and pregnancy

Cases of ZIKV/HSV-2 coinfections have already been described in pregnancy in several prospective studies [52]. In addition, one comparative study showed that HSV-2 infection induces cytotoxic and inflammatory effects in the sterile vaginal system, while ZIKV infection alone does not result in obvious epithelial destruction [152].

HSV-2 induces immunomodulation and proinflammatory cytokine production (including interleukins IL-8 and IL1 $\beta$ ) making it an ideal antagonistic or synergetic partner in enhancing ZIKV pathogenicity in pregnancy (Figure 4: Pathogenesis changes) [152]. ZIKV RNA accumulation in the placenta of pregnant C57BL/ 6 mice exposed to HSV-2 at day E8.5 (equivalent to the first trimester in humans) and then infected with ZIKV at day E11.5 was significantly higher compared to pregnant mice monoinfected with ZIKV alone (Replication promotion). In HSV-2-induced infection, TAM receptor expression may 
favor cell susceptibility to ZIKV (entry) as well as permissivity resulting from inflammation (Figure 4: Tropism benefit) [98]. Interestingly, Brazil's northern region, which has a high number of ZIKV-related microcephaly cases, is also an area with strong seroprevalence for HSV-1 and HSV-2 (Figure 4: Epidemiology influence) [50,149,151,153].

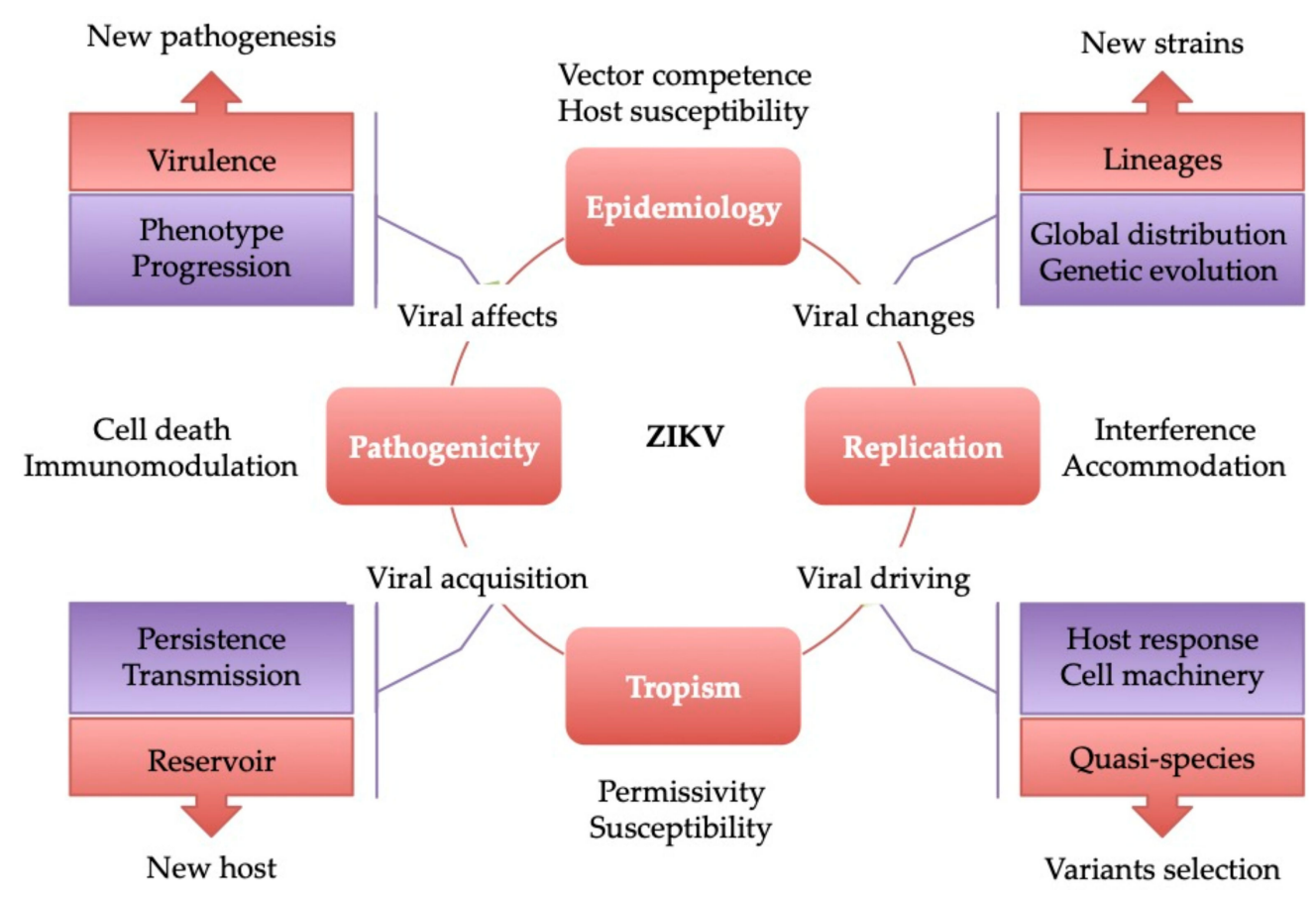

Figure 4. Coinfection with a latent virus influences the ZIKV infection cycle pattern in humans. Replication: In contrast to viral competition (interference), viral transcription is almost completely silenced in latency, benefitting ZIKV in terms of using the cell machinery (purple) for promoting its replication and the selection of new variants (red) without clearing the latent viruses already affecting host response (accommodation). Tropism: Cell specificity in latency establishment offers ZIKV a wide range of reservoirs, changing its tissular tropism (permissive or susceptible), and promoting its persistence as well transmission (purple) to other hosts via new modes (red). Pathogenicity: Coinfections can modulate virus virulence (red) from immunomodulation events and cell death activation (apoptosis), resulting in changes to ZIKV pathogenicity (red), thereby altering disease severity (outcome and phenotype) (purple). Epidemiology: The latent virus may influence ZIKV epidemiology by promoting nucleic acid mutations (substitution) in the viral genome, thus creating new strains (purple), new lineages (red), and/or adapted variant selection, thereby affecting vector competence as well as host susceptibility.

In one study, coinfection with HSV-1 and ZIKV has already been demonstrated in humans with meningoencephalitis [154]. This study suggests an increase in cellular damage associated with ZIKV and the herpes virus family infection and/or in ZIKV facilitating the reactivity of other herpes viruses and neuronal injury by indirect mechanisms (e.g., apoptotic stimulation, inflammasome, and NLRP3 activation) (Figure 5: Reactivation) [154]. Herpes simplex viruses (HSV-1 and HSV-2) share some clinical features and tissue tropism, including of the brain and placenta, with ZIKV, suggesting the possibility of understanding the molecular mechanisms of ZIKV pathogenicity based on HSV findings [39,136,155,156] and /or in a coinfection context (Figures 4 and 5). As suggested above, the influence of HSVs on ZIKV biological systems may concern replication (e.g., a high viral load), tropism (e.g., neuronal and placental tissue targets), and direct or indirect pathogenesis (e.g., apoptosis and immunomodulation), as shown in Figure 4. HSV-1 and HSV-2 may be the partners to promote ZIKV pathogenicity, leading to the emergence of ZIKV-linked GBS and CS in arbovirus endemic areas with high HSV seroprevalence. 


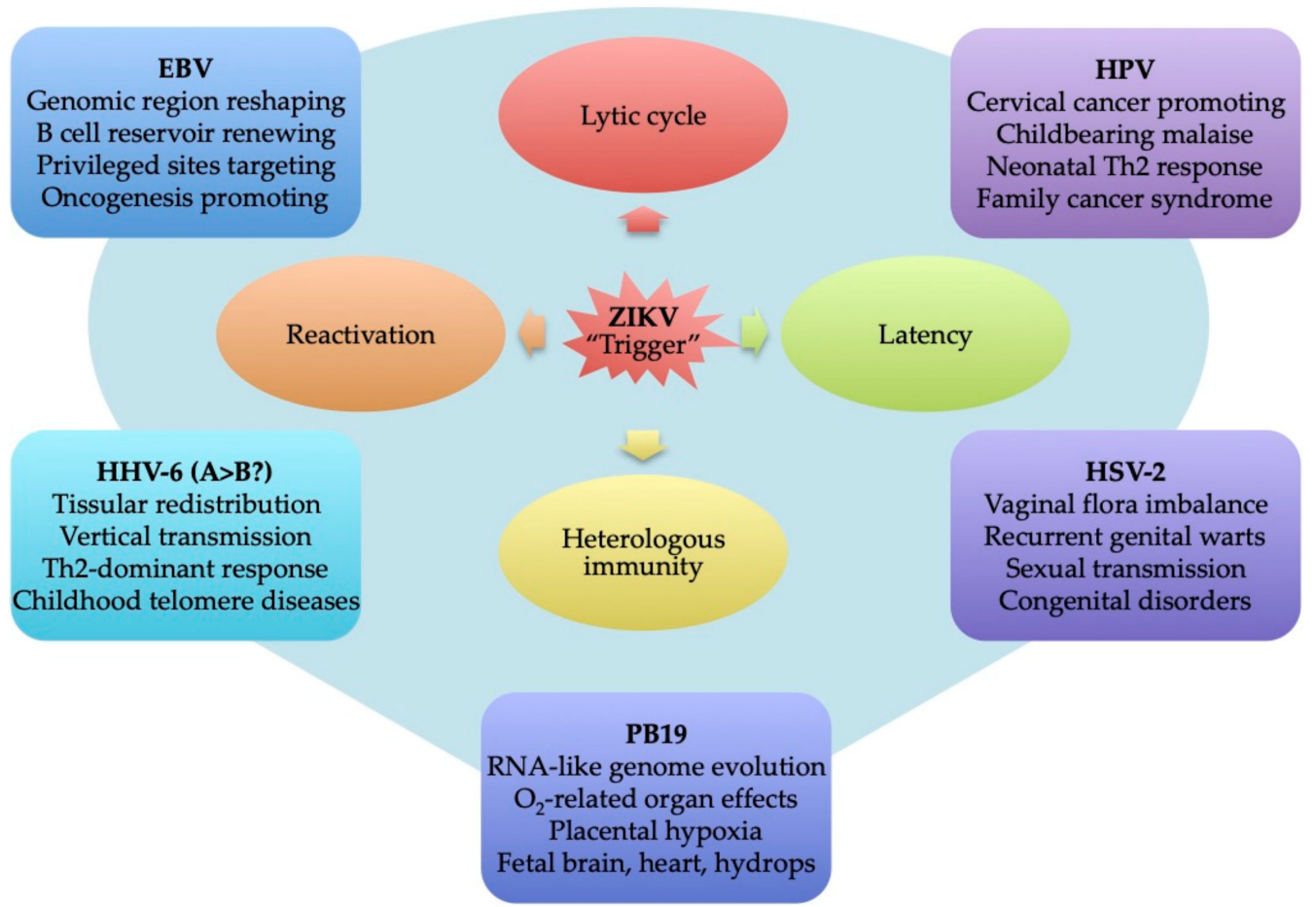

Figure 5. ZIKV infection impacts human latent virus biological systems. ZIKV acts as a triggering factor of reactivation (orange) to promote the switch from latent to lytic replication. In contrast to the latent phase, viral cointeractions in the lytic cycle are mostly competitive events (red) (interference: reduction, blocking, or inhibition replication) to monopolize cell machinery, leading to latent virus exclusion (clearance). ZIKV exposition in the viral latent phase results in cooperation (enhancement and accommodation) or in neutrality (no effect or coexistence), in which interactions are not exclusive (green). Heterologous immunity (yellow): ZIKV coinfection can modify the immune response against latent viruses, providing protective immunity or leading to immunopathology, referred to as the heterologous immune response. Square (blue and purple): depending on latent virus systems (e.g., HSV-2, EBV, HHV-6, B19V, and HPV), mixed infections with ZIKV affect the virus (e.g., genome and pathogenicity) as well as the host (e.g., immunomodulation, tissue tropism, and diseases).

Interestingly, a new variant of human HSV-2 from Brazilian HIV-1 coinfected subjects has been identified. Its impacts on the pathogenicity of HSV-2 infection and HIV / HSV-2 coinfection need further investigations [151]. This fact shows the continued evolution of the HSV-2 biological system associated with the coinfection context. In addition, similarly to DENV/CHIKV, HSV-1/2, HPV, and HIV coinfections with ZIKV, multi-complex ZIKV systems need to be considered from more of an epidemiological perspective (e.g., seroprevalence) in order to develop control and prevention strategies (Chapter 3) [157].

- $\quad$ Potential ZIKV/HSV-2 coinfection prevention strategies

To date, few vaccines have been developed against genital HSV-2. From the hypothesis that HSV prevention might limit damage due to ZIKV pathogenesis, efforts to design an effective vaccine against HSV-2 need to be made and, indeed, some works are already in progress [158]. Of particular encouragement is the recent development of broad-spectrum virucidal gold nanoparticles mimicking heparan sulfates that provide nontoxic virucidal action against HSV-2 and ZIKV [159]. Additionally, antiviral activity against HSV-2 is also effective in mice models and ex vivo vaginal tissue culture models. However, continued efforts are required in terms of improving care systems and providing education to reduce inequalities (e.g., spatial, sexual, ethnic, and economic).

\subsubsection{Human Herpesvirus Virus (HHV-6A/B): Immunomodulated Viruses}

Human herpesviruses 6A and B (HHV-6A and B) belong to Betaherpesvirinae subfamily, which includes human cytomegalovirus (HCMV) and human herpesvirus 7 (HHV-7). Compared to the ubiquity of HSVs, HHV-6A/B have a longer (days) replication cycle, and 
the slower spreading results in characteristic infected cell enlargement $[114,160]$. HHV6A/B cause tropism of lymphocyte T CD4+ and can also infect monocytes/macrophages; epithelial, endothelial, and smooth muscle cells; and fibroblasts (Table 1) [161]. The epidemiological, biological, and immunological parameters support differences between HHV-6A and HHV-6B [162]. HHV-6A infection remains uncertain and might be acquired in later ages, showing few clinical signs [163]. However, the presence of HHV-6A DNA in almost half of the endometrial cells of women with idiopathic infertility may support such a cause-effect link $[164,165]$. By contrast, primary HHV-6B infection typically causes roseola infantum, which occurs in $90 \%$ of children within their first two years of life (the sixth disease) [162]. In adults, HHV-6B infection is mostly asymptomatic or responsible for mononucleosis-like syndrome. From here, HHV-6B can enter a state of long-life latency in the lymphoid tissues (e.g., blood, spleen, and lymph nodes) and especially detected within hematopoietic progenitor cells and myeloid cells [166]. In humans, these viruses (HHV$6 \mathrm{~A} / \mathrm{B}$ ) persistently infect 70 to $90 \%$ of the human population, and the seroprevalence of HHV-6 viruses can be up to $100 \%$ in most regions of the world [167]. Several experimental works support that the limited clinical manifestations of singular HHV-6 infection are related to its immunomodulator functions, which promote the establishment of specific viral latency in each immune cell type (e.g., CD4T, CD8, and macrophages/monocytes), providing evidence of a positive coevolution between this virus and humans [168].

- An HHV-6-specific latent form: iciHHV-6

The integration of the HHV-6 genome into host DNA, also referred to as inherited chromosomally integrated HHV-6 (iciHHV-6), corresponds to a unique mechanism of viral latency among herpesviruses. At the terminal regions of its genome, HHV-6 possesses "telomere-like repeats", allowing its integration near the telomeric junction of host chromosomes by homologous recombination of its direct repeat (DR) region of "TTAGGG" motifs [169-171]. The genome is transmitted during cellular division as an integral part of the host genome (Table 2), and from one generation to the other (to $50 \%$ of the offspring) via viral integration into germline cells (gametes), i.e., via DNA [172]. Approximately $1 \%$ of the human population possesses a copy of HHV-6 in the genome of each somatic cell [173]. Interestingly, iciHHV-6A shows particularly high expression in the brain and testes [174].

- Latent iciHHV-6 regulation

The maintenance of proviral latency is commonly based on restricting viral replication to some latency-associated genes, allowing a limited host immune response and virus persistence in niches until cell death. Transcriptional studies of the iciHHV-6A/B genome describe four latency-associated transcripts of HHV-6A/B (H6LTs), which correspond to ORF99, ORF142, and ORF145 proteins [167]. Expression of the U94 transcript also allows the establishment and maintenance of latency by inhibiting viral lytic replication in HHV6A/B-infected peripheral blood mononuclear cells. As per herpesvirus latency regulation, RNA-seq analysis from patient-derived iciHHV-6A cells shows various epigenetic process markers to ensure silencing of the HHV-6 virus genome [114]. Moreover, small noncoding RNAs (sncRNAs) such as miR-U86 can prevent lytic cycle activity. By inhibiting the expression of U86 at the transactivation step (initial reactivation), miR-U86 suppresses the shift to the lytic cycle to back to the latency stage [114,167]. Although details regarding latency maintenance are limited and it remains a subject of ongoing investigations, its regulation highlights a possible reversible situation, meaning that iciHHV-6B reactivation can promote replicative as well as non-productive cycles (Table 2).

- Reactivation and related diseases

iciHHV-6B is difficult to isolate, presenting challenges for its study, though a recent study argued that iciHHV-6 is able to reactivate even if superinfection with a second HHV$6 \mathrm{~B}$ strain occurs (Table 3 ). This argues not only the ability of iciHHV-6B to reactivate but also the role of the superinfection of other pathogens on the immune state of iciHHV-6-positive patients $[167,175]$. Some studies have postulated that iciHHV-6 positivity benefits human 
health by enhancing antibody responses against superinfection by a second pathogen, such as HCMV or EBV $[174,176]$. By contrast, previous work has indicated that HHV-6A infection promotes EBV and HCMV reactivation, and severe lymphopenia in HCMVpositive patients with high seroprevalence to HHV-6B coinfection are more susceptible to developing serious clinical manifestations [175]. Moreover, the integration of HHV-6A/B in some chromosomes has been reported to potentially generate telomere dysfunctions and/or telomerase mutations with greater risk of developing diseases such as cardiovascular diseases $[169,177,178]$. The above contradictions need further investigation using cutting edge tools, particularly concerning the reactivation potential of HHV-6B and the impact of the telomere-integrated form on host health. HHV-6 reactivation may also depend on the individual immunological changes occurring all along the reproductive life. However, pregnancy is frequently related to latent virus reactivation, including HHV-6 [179-183].

- Pregnancy

HHV-6B is usually acquired in early childhood (from birth to two years) and explains why cases of primary maternal infection are extremely rare. Moreover, HHV-6B seems unable to replicate in endometrial cells, in contrast to HHV-6A, which could be related to the development of infertility in women [184]. In fact, HHV-6A infection may be especially responsible for the immune profile dysregulation of endometrial cells, and its presence in the vagina represents a risk of sexual transmission to partners as well as vertical transmission to the fetus and to newborns at delivery (at birth) $[164,185,186]$. Since Hall's estimation of an HHV-6 vertical transmission rate of approximately $1 \%$, much evidence has accumulated to support this mode of transmission as well as its link to possible congenital impacts $[183,187,188]$. In utero, HHV-6 is an immunomodulatory factor that promotes cytokine secretion, IL-15/IL-18 in trophoblasts, and a reduction in endometrial human leukocyte antigen G (HLA-G) and Mucine 1 (MUC1) in favor of congenital problems, such as miscarriage. Moreover, HHV-6 stimulates the production of cytotoxic natural killer (NK) cells, which control the level of apoptosis at the decidual surface, but which limit the level of regulatory $\mathrm{T}$ cells (Treg) that prevent fetus rejection. By facilitating a Th2 switch environment associated with interleukin production (IL-4, IL-5, and IL-10), HHV-6 also plays a role in infertility, as well as in implantation failure [164]. A recent in vitro study demonstrated that HHV-6A infection dramatically changes the expression profile of miRNAs and control of the trophoblast cell adhesion of endometrial cells and trophoblast cell misattachment on endometrial cells [165]. As per various other environmental factors (e.g., hypoxia, signaling pathways, and epigenetic modification), HHV-6 infection may dramatically affect embryogenesis by dysregulating the production of the more than 500 miRNAs connected to this process.

Although HHV-6 is not considered as important a TORCH pathogen as other betaherpesviruses (e.g., HCMV), all of the above examples provide evidence of the immunomodulatory features of HHV-6A that alter a woman's reproductive life and, especially, pregnancy outcome. Previous work indicates that HHV-6A infection promotes HCMV reactivation and patients with severe lymphopenia (+) HCMV with a high seroprevalence to HHV-6 coinfection are more susceptible to developing serious clinical manifestations [175].

As a consequence, HHV-6 may trigger its own molecular mechanisms, which alters immune cell interactions at the fetal-maternal interface resulting in fatal fetal outcomes but also influence the immune response to others congenital pathogens in the context of the coinfections in pregnancy.

- $\quad$ ZIKV/HHV-6 coinfection and pregnancy

In view of its high seroprevalence, the frequent detection of HHV-6-IgG (past infection) during diagnosis of ZIKV infection is not surprising [99,189-192]. HHV-6 and ZIKV infection consequences in the fetal development may be the same with a risk of misdiagnosis from clinical evidence. By contrast, the RNA of HHV-6 has been identified in several post-mortem tissues (e.g., thymus, kidney adrenal gland, and liver) of newborns with CZS. This raises important questions, firstly, about the origin of HHV-6 infection 
(primo-infection or reactivation) and the subgroup HHV-6A/B. Pregnancy, as well as ZIKV infection, can trigger factors related to HHV-6 replication. As per HCMV, HHV-6 may promote ZIKV infection in utero, mirroring a potential facilitating mechanism of ZIKV tropism and/or local replication. As a consequence, the sequence of virus acquisitions is unclear: iciHHV-6B reactivation or HHV-6B infection may or may not be prior to ZIKV infection in pregnancy. This, more generally, indicates the establishment of a pathogenicity cooperative process between HHV-6 and ZIKV in female urogenital tracts which needs to be further investigated, paying particular interest to the iciHHV-6-positive population (Figure 5) [174]. Population-based studies (e.g., HHV-6), such as of genetic predisposition, may be one future option for developing a better understanding of the ZIKV/microcephaly association.

\subsubsection{Epstein-Barr Virus (EBV): Lymphocryptovirus}

EBV belongs to the Gammaherpesvirinae subfamily, the third subfamily of herpesvirus, which shows both cell- and host-specific tropism. Unlike alpha- and betaherpesviruses, with a classical lytic cycle, EBV infection is characterized by the predominance of a latency period (Table 1) [114]. EBV infects essentially naïve B cells in the blood to promote B cell differentiation and to establish viral latency in memory B cells with a long lifespan (Table 2) [114]. In the same individual, EBV latency can show multiple types of persistence with continuous changes through the adaptation of EBV latency according to the cells' physiological states (B cells), the origin, and host responses, including their immunological immune state and the environment. EBV is one of the most ubiquitous among the herpesviruses in humans [193]. It is estimated that more than $90 \%$ to $95 \%$ of adults worldwide present latent EBV infection in their B-lymphocytes. In general, EBV infection is contracted in childhood and is often subclinical. In young adults, it presents more of the classic findings of infectious mononucleosis with viral chronic detection in the saliva and blood [193]. Apart from in the nasal mucosa and tongue, EBV is commonly detected in lymphoid tissues, as well as in the intestines and liver, but with less importance in neural and genitourinary tissues [194].

- $\quad$ Latent genome forms of gammaherpesviruses

Unlike alphaherpesviruses, gammaherpesvirus episomes needs to attach to cellular chromosomes so as to limit the risk of losing the viral genome in the dividing cells, such as B cells. The "tethering" of the viral genomes to cellular chromosomes results from viral proteins interacting with chromatin-binding proteins during mitosis $[114,142]$. The Epstein-Barr nuclear antigen 1 (EBNA1) protein links specifically to chromatin host factors during mitosis. Origin-binding proteins (OBPs) also contribute to DNA attachment and recruitment of cellular proteins for replication $[114,142]$. From there, the latent gammaherpervirus episomes can duplicate in synchrony with the cellular cycle, once per cell cycle and during the $S$ phase (Table 2).

- Common viral latency maintenance strategies

As per HSV, limiting the expression of EBV latency genes (transcription) requires chromatin interactions and changes, implicating epigenetic regulation. The Epstein-Barr nuclear antigens (EBNAs; e.g., EBNA-2 and EBNA-LP) and the latency-associated membrane proteins (LMPs; e.g., LMP1) play a major role in transcriptional regulation of viral silencing through chromatin condensation changes, histone modifications, or at the level of DNA methylation [114,142,143]. The sncRNAs, Epstein-Barr Virus-Encoded RNA 1 (EBER1) and Epstein-Barr Virus-Encoded RNA 2 (EBER2) are also involved in EBV latent cycle regulation. Both cell miRNAs and viral miRNAs drive the maintenance of latency and/or repression of the expression of the viral gene during the lytic cycle, such as in the example of EBV BamHI-A rightward transcript (BART20-5p) miRNA, which targets the EBV genes BZLF1 and BRLF1 [114,142,143]. The viral latency features define each EBV latency type, whereas some of them support the oncogenesis properties via promoting the survival of latently infected B cells (Table 2). 


\section{- Latency and oncogenic potential}

Direct evidence for the tumor formation potential of the EBV latency period encompasses growth signal induction, apoptosis prevention, antiviral immune control, and genome instability, referred to as the IARC package $[114,143,195]$. For example, LMP-1 and LIMP-2 promote $\mathrm{B}$ cell survival by upregulating NF- $\mathrm{KB}$ signaling and mimicking the $\mathrm{B}$ cell receptor, respectively. The BamHI fragment $\mathrm{H}$ rightward open reading frame 1 (BHRF1) miRNAs and the EBV-encoded small RNAs (i.e., EBER1 and EBER2) inhibit apoptosis and promote passage through the cell cycle [114,143]. Moreover, some mutations can appear and are responsible for triggering the spontaneous lytic phase and, often, increasing cell immortalization and carcinoma risk.

As a consequence of these effects, EBV is a direct causative agent of different forms of lymphoma, such as Burkitt's lymphoma and Hodgkin's disease, driven by the factors of nature and the context of reactivation, which leads to oncogenesis [196].

\section{- Reactivation and coinfection}

In general, environmental stressors (e.g., chemotherapy and radiotherapy), hypoxia, hormonal dysregulation, and coinfection with other pathogens can induce a switch to the lytic phase. Host immunosuppression by HIV infections is often associated with EBV reactivation, favoring EBV dissemination [197]. A number of studies have been conducted to determine the impact of EBV co-exposition with HIV lymphopathogenic virus on the progression of infectious diseases in terms of kinetics, severity, complications, and chronicity, but especially as a co-trigger of oncogenesis [195]. EBV and HIV promote B cell proliferation from synergic activity, such as through stimulating and binding to B cells by the same cell surface protein complex, such as the programmed death-1/programmed death-ligand 1 (PD/PDL-1) pathway [195]. While EBV may promote HIV-1 replication, HIV-1 protein expression growth is advantageous for EBV-driven immortalized B cell proliferation [195]. In other words, HIV infection increases the incidence of each of these B cell malignancies. Following HIV coinfection, EBV induces the expression of LMP1, which mimics CD4+ T cell signals and upregulates NF- $\mathrm{kB}$ signaling to promote B cell immortalization, B cell survival and, thus, tumorigenesis (Table 3).

\section{- Pregnancy}

The reactivation of EBV may frequently occur in pregnancy [198]. A cohort study estimated a $98 \%$ EBV seroprevalence in women and showed that pregnancy status is associated with a 35\% EBV reactivation rate [199]. During pregnancy, the transplacental transfer of IgG antibodies from the mother protect the infant against many viruses, including EBV [198]. Although no more proof is provided here for possible EBV reactivation effects on congenital disorders, some studies have shown that, following EBV infection, the placental cells change (i.e., they become larger, longer, rounder, and have less-condensed chromatin and their cytoplasmic volumes are increased) [200-202]. Another study demonstrated that EBV alone may infect human syncytiotrophoblast cells associated with interleukin-2 (IL-2) and interleukin-6 (IL-6) secretion [198,203]. It has been shown that EBV is also a perfect partner to (+) HIV mothers [198]. The PD/PDL-1 signaling pathway plays a major role in the maintenance of the placental immunodepressive environment by promoting the secretion of immunosuppressive factors (cytokines), which reduces lymphocyte proliferation in the trophoblasts and amniotic epithelial cells (KIM). For example, the EBV/HIV-induced expression of PD-L1 on antigen-presenting cells results in the inhibition of T cells, making the placenta as an ideal niches for both viruses. Moreover, HIV-1/EBV may also especially perturb the cytokine secretion profile and pro-inflammation cell modulators by favoring a shift from a Th1 to a Th2 response, crucial in maintaining pregnancy [198]. As per the ubiquitous nature of global herpesviruses, their coinfection with HIV is a concern in regard to the outcome of pregnancies in Africa, in which HIV seroprevalence remains high [204]. Each region may be characterized by various co-exposition schemes between EBV and other viruses, specifically abundant in this area, such as ZIKV in the arbovirus region.

- $\quad \mathrm{ZIKV} / \mathrm{EBV}$ coinfection and pregnancy 
In spite of their genetic differences and distinct life cycles, the clinical signs of ZIKV and EBV infections may be confounded, such as for hepatitis, rash, arthritis, encephalitis, and renal diseases. The etiologic importance of ZIKV and EBV to these diseases changes depending on regions and seasons [39,205-207], making them difficult to diagnose in arbovirus endemic areas where there is the possibility of co-exposition. Endemic areas provide an opportunity for ZIKV-induced EBV to recurrently reactivate (Figure 5), impacting on ZIKV disease progression (Figure 2) by driving the viruses (EBV and ZIKV) to spread along tissues to new niches according to the immunological and physiological status. The initial regions colonized by EBV can differ, including lymph nodes and B cells, and constantly change. Interestingly, following the route of the respiratory tract, EBV can already be detected in neural and genitourinary tissues [194]. However, no consensus is observed in the literature regarding the risk of ZIKV-induced EBV reactivation. One in vitro investigation showed that fetal membranes (FMs) are fully permissive to herpesvirus monoinfection, such as with HSV-1 and HSV-2, VZV, and HCMV, though with the exception of EBV, HHV-6, -7, and -8 [208]. Curiously, in young pregnant woman from Southern Veracruz, Mexico, fetal post-mortem histological investigations demonstrated codetection of ZIKV RNA with EBV in the cortex and with HHV-6 in the kidneys, as well as ZIKV antigen production in the thymus [99].

The last ZIKV outbreak in South America was associated with an atypical increase in microcephaly in pregnancy which at this point had become a matter of particular concern. In turn, ZIKV-induced EBV reactivation in an immunodepressive context may result in malignancy hyperpathogenicity. Recurrent reactivations lead not only to the renewal of the viral reservoir, but also to a reshaping of the population of EBV strains in genomic regions encoding latency regulation, thus determining the continuous emergence and/or abortion of oncogenic EBV strains. Although rare, the description of one case of placental EBV-associated B cell lymphoma of fetal origin is particularly attention-grabbing [209]. Especially, the increased risk of Castleman's disease (lymphoma and follicular dendritic cell tumor development) results from EBV infection in pregnancy [210,211]. In arbovirus endemic areas, co-exposition of EBV / ZIKV may result in the development of a pathogenic cooperative mechanism to improve the adaptation of each virus in humans, thus enhancing the risk of oncogenesis in the mother and during fetal development in pregnancy (Figures 4 and 5).

\section{- Potential ZIKV/EBV coinfection mechanisms}

In view of HIV co-exposition experiences, EBV may have an immunomodulatory effect on ZIKV protection from the female urogenital tract response by (1) reducing the percentage of B cell and T cell pools in the female genital tract; (2) causing imbalance in Th1/Th2 as a switch necessary for placental maturation; and (3) a disruption of IFN-JAK and pro-inflammation signaling of the trophoblast layers. EBV control over the production and secretion of cytokines (IL-2 (EBI3/p355 subunit), IL-6, and IL-12) [212-215] and the production of IFN gamma defines the placental permissivity to ZIKV and its effects on barrier integrity. Even though not yet clearly demonstrated, PD-L1, which expression is modulated by EBV and HIV, may be involved in CZS. Finally, the anti-apoptotic action of EBV via EBV-BHRF1d/BNIP3 proteins may contribute to ZIKV placental replication and dissemination to particular epithelial cells, such as Hofbauer cells [216,217].

\subsection{Other Latent Virus Concerns: Human Parvovirus and Human Papilloma Virus}

\subsubsection{Human Parvovirus B19 (B19 Virus or B19V)}

Human parvovirus B19 (B19 virus) is a small single-stranded DNA virus belonging to the Parvoviridae family. B19 is the only member of the genus Erythroparvovirus, which reflects its restricted replication to erythrocyte precursors (e.g., bone marrow and fetal liver) (Table 1) [218,219]. B19 virus is generally contracted in early childhood and is responsible for the most common rashes in school-aged children, such as slapped cheek syndrome or fifth disease (behind measles, scarlet fever, rubella, and Duke's disease) [220,221]. Once the acute phase is over, B19V may persist in various human sites, such as the bone mar- 
row, synovium, liver, spleen, and testes [218], mirroring lifelong viral niches as well as further emerging patterns of human pathogenesis [220]. Although the diseases are mostly autoresolved, B19 virus infection is also linked to hepatitis, cardiomyopathies, respiratory illness, autoimmune diseases, and neurological disorders (e.g., encephalitis, encephalopathy, and meningoencephalitis), and is often associated with the host hematological and/or immunological state $[220,222]$.

- From latency to the immunogenic process

In contrast to herpesviruses, the research on the persistent features and nature of B19 virus (e.g., latent, chronic, and slow down infection) is in the early stages (Table 2). Comparative studies with the adeno-associated virus (AAV), a human Dependoparvovirus belonging to the same family as $\mathrm{B} 19 \mathrm{~V}$, support that $\mathrm{B} 19$ virus might mimic the $\mathrm{AAV}$ process to establish stable latency by integrating into the human chromosome in a site-specific manner, referred to as the proviral form [223]. In details, B19V shows identical terminal repeat sequences to AAV (i.e., palindromic repeat sequences), serving in the packaging of DNA and integration [223]. Due to this structural homology, P19 may adopt a proviral form in which the virus acts as an integral part of the host genome. Nevertheless, direct evidence of B19 virus latency integrated forms is lacking.

- From latency maintenance to the lytic process

Downregulation of the B19-induced cell DNA replication in erythroid cells is the hallmark of B19V survival in humans. In fact, B19V takes advantage of host cell division to preserve its genomic stability and integrity by inducing a DNA Damage Response (DDR). This B19-induced "DDR" activation leads to cell division and arrest in which the virus hijacks the cellular DNA replication machinery for its own benefit, which consequently affects host genome reparation and the resumption of cell cycle progression $[218,223,224]$. Transcriptomic investigations of B19-infected human erythroid progenitors (EPCs) confirm changes in cellular gene expression leading to global downregulation of cellular DNA replication, while viral DNA genome replication takes precedence. Instead of participating in the host DNA repair processes, the host DNA polymerase and available DNA replication factors are monopolized to the initiation of the viral lytic phase [224]. The destruction of red blood cell precursors and erythropoiesis blockage are a key pattern of B19 virus lytic activity with oxygen-triggered factors [225]. This hypoxia also contributes to B19 activation by upregulating erythropoietin (EPO) and its receptors (EPOrcp) via promoting JAK2 and STAT5, ERK, and PI3 kinase [218,224,225]. These viral non-structural proteins (NS proteins) mainly play an important role in successful viral multiplication. The NS1 protein upregulates the IL2 inflammatory response, STAT3/PIAS3 signaling pathway, inflammation via NF-kappa beta, and IL-6 expression [218,224]. It remains uncertain as to whether the persistence of B19 virus in humans is correlated with productive or unproductive infections and whether there is any cell specificity, e.g., for erythroid versus non-erythroid cells. To date, the placental endothelial cells are the only non-erythroid cells in which the B19 virus replicates [218]. B19 virus infection in the mother may create a particular pathogenicity outcome, leading to severe congenital complications; in particular, microcephaly is a feature common of cellular "DDR" disorders in ZIKV congenital infection [226].

- $\quad$ B19V particular congenital context: reactivation and/or vulnerability or hazard

Although rare, B19V vertical transmission can still occur without clinical evidence in mothers [227]. B19 vertical transmission increases with pregnancy progression, namely, $15 \%, 50 \%$, and $60 \%$ in the first, second, and third trimesters, respectively, and is linked to a growing demand of the fetus from the mother in terms of energy and oxygen from erythrocytes and EPO regulation erythropoiesis [228,229]. The pregnant weeks of 13 to 20 weeks correspond to the establishment of a connection between with maternal blood and fetal circulation, which is temporarily subjected to hypoxia events and inflammation. Hypoxia-induced inflammatory foci result in a complicated, maternally mediated cellular immune response at the placental interface, while the barrier permeability increases and, 
as a result, facilitates B19V accessibility to the fetal erythroid progenitor cells associated with an immature immune system [230,231].

The destruction of these red blood cell precursors in the fetal liver by conjugating cytotoxic apoptosis and cell lysis is the key pattern of the B19V feto-pathogenicity mechanism [232]. Anemia, hydrops fetalis, and cerebral artery blood flow increases are consequences of the blocking of fetal erythropoiesis [227]. B19V-induced neuronal disorders and cardiac failure in fetal development are evidence of one oxygen-dependent pathogenicity mechanism [222,227]. In addition, the neuronal cells and fetal cardiomyocytes express the globoside protein. Globoside (i.e., P-antigen or Gb4) and its co-receptor, $\alpha 5 \beta 1$ integrin, are described as the primary major receptors for B19 infection $[233,234]$ and are highly expressed in human erythroid cells. Globoside is detected on villous syncytiotrophoblasts and extravillous and villous cytotrophoblasts of the placental tissue [229,235]. Moreover, B19V-NS1 and B19V-VP2 viral proteins increase the expression levels of globoside and its co-receptor, $\beta 1$ integrin, in BeWo cell cultures, which could facilitate B19V transmission at the maternal-fetal interface $[229,236]$. Nevertheless, studies have proposed that rather than promoting viral cell internalization as a B19V receptor, globoside may be only involved in the post-entry of viral replication $[229,237,238]$. To date, evidence of B19V infection as the direct cause of congenital disorders is still lacking [239]. The pattern of B19V infection in pregnancy may be rather associated to a boost in the pathogenicity of other coexposed pathogens, causing severe clinical complications [220,223]. For example, interaction of the HIV gp120 protein with the globoside receptor is a feature shared by B19V, supporting the B19V/HIV cooperative concept and also possible HIV-induced B19V reactivation [240-242].

- Arbovirus/B19V coinfection

In Brazil, B19V is the most frequent cause of rash/fever infections in cases where serum testing is negative for arboviruses and rubella, and several studies have shown an increase in PB19 rash/fever cases in a spatiotemporal manner compared to arboviruses and rubella $[243,244]$. Parvovirus B19 has been detected in $17 \%$ of cases when assaying the plasma of Brazilian patients with dengue fever-like symptoms, while samples were negative for arbovirus and were originally misdiagnosed (falsely positive for DENV) [245-249], A similar trend has also been reported for ZIKV [52,250,251].

Infections due to B19V and ZIKV pathogens share similar clinical manifestations, suggesting an overlap of some pathogenicity mechanisms [39,40,248,252-254]. The B19V genome is characterized by high rates of observed nucleotide substitutions $\left(1-3 \times 10^{-4}\right.$ substitutions/site/year), which are comparable to the substitution rates of ssRNA viruses that mostly correspond to the groups of re-emerging viruses, including ZIKV. The natural evolution of the genomes of these viruses might contribute to extending, and thus continuing, the spectrum of possible host cells, mirroring a long-term coevolution with humans but also, potentially, its pathogenicity changes (Figure 4) [255-257]. These opportunities to set up viral (B19V / ZIKV) coevolutions that facilitate the adaptation to ZIKV in humans, growing in genetic diversity and the development of new atypical types of pathogenicity, are of particular concern in terms of the outbreak context and vulnerable populations such as mothers and infants [258].

- $\quad \mathrm{ZIKV} / \mathrm{B} 19 \mathrm{~V}$ coinfection in pregnancy

In South America, there is a conflicting picture regarding whether the increasing incidence of microcephaly mirrors the emergence of Congenital ZIKV Syndrome in the context of an outbreak [27]. The recent ZIKV/B19V codetection in fetal tissue lesions of a severe congenital case with hydrops fetalis casts doubt over the willingness to assign responsibility to ZIKV for all fetal pathology in areas of high arbovirus density [101,259]. In fact, both of these viruses target the fetal-placental unit associated with singular pathogenicity mechanisms, which can combine to create new congenital phenotypes, offering even more possibilities for fatal effects in the fetus and mother $[260,261]$. In pregnancy, the B19Vinduced erythropoiesis dysregulation affects fetal development by hypoxia-induced brain 
damage disorders and DDR promotion, resulting to hydrops fetalis. In arbovirus endemic areas, B19V could act by promoting Congenital ZIKV Syndrome. Thus, the increasing incidence of $\mathrm{B} 19 \mathrm{~V}$ in some areas of Brazil deserves more attention due to the possibility of ZIKV/B19V syndemism.

\subsubsection{Human Papillomavirus (HPV): Human Cervical Cancer}

Human papillomavirus (HPV), a non-enveloped, double-stranded, circular DNA virus, belongs to the Papillomaviridae family with currently almost 200 listed HPV subtypes (Table 1) [262]. HPV infects only humans, both males and females, and can replicate in the skin and the mucosa epithelia of the mouth, throat, and urogenital tract as well as their associated secretions $[263,264]$. HPV can be contracted by direct skin contact or by other forms of intimate contact (e.g., vaginal and anal sex) [264,265]. HPV is, globally, a major sexually transmitted infection and occurs at least once in a person's lifetime $[262,263]$. The major risk factors for acquiring additional HPV subtypes include multiple sexual partners, smoking, using immunosuppressants, and pregnancy [262]. Several types are carcinogenic and classified in low- or high-risk categories. For the low-risk HPV types (LR-HPV), the majority of clinical lesions present as warts rather than as malignancies $[263,266]$. HPV types 6/11 are responsible for condyloma acuminatum in the urogenital tract (genital warts) as well as juvenile and adult recurrent respiratory papillomatosis [262,263]. High-risk HPV subtypes (HR-HPV), in comparison, are responsible for high-grade intraepithelial lesions in male (i.e., the penis) and female (i.e., the vulva, vagina, and cervix) urogenital tracts which progress into malignancies. All cervical cancer cases are due to HPV, and the majority of cases is caused by the HPV-16/18 subtypes. HPV is responsible for all cases of cervical cancer (50\% due to HPV-16) and 70\% of vaginal cancer, with HPV- 16 being the causative subtype $50 \%$ of the time [263]. Although most high-risk HPV infections are resolved in less than two years, the ability of some to persist throughout the lifetime increases the risk of developing HPV-associated cancers [267].

- $\quad$ Latent forms and maintenance

At least two HPV DNA latency mechanisms have been proposed, with possible overlap, but are especially related to cancerogenesis. Oncogenesis as related to specific HPV subtypes may result from the latency process linked to particular strains, according to episomal versus proviral forms (Table 2).

Restricted to the epithelium basal cells, the establishment of HPV DNA in the episomal latent form is associated with expressing a limited number of key viral proteins which, together, establish and maintain HPV latency (e.g., E2 E6, and E7 viral genes) [264]. To support viral DNA replication and transcription, HPV uses host DNA replication mechanisms which induce DNA damage responses (DDRs) and host genomic instability. Various epigenetic processes are involved in facilitating chromatin access, interactions with associated factors, and especially viral genome tethering to chromosomes via the HPV E2 protein (e.g., histone modulation and chromatin condensation level changes) [267]. During cell division, the HPV E2 protein links with the host cell chromatin through the hypermethylation of its specific binding sites and, thus, promotes transcription of the viral E6/E7 proteins [267]. The E6 and E7 tumor activators, by repressing the p53 and pRb proteins, respectively, override the classical cell cycle pattern to "S phase quiescent". While E6/E7 promote neoplastic transformation of the targeted tissue, E2 regulates viral replication in non-cycling cells, resulting in tissue hypertrophy [267]. The E5/E6/E7 protein complex is also a suppressive immune factor associated with the downregulation of the transcription of interferons (IFNs), cytokines, and IFN-stimulated genes (ISGs), as well as the inhibition of the JAK-STAT signaling pathway, making it a perfect environment for virus reactivation.

However, from recent evidence regarding viral recombination with chromosomal DNA, HPV16/18 can persist in proviral forms. Integration into the host's DNA genome may concern cancer-derived epithelial cells more, in which the increase in the integration of viral DNA and its methylation is correlated with disease progression [268]. In addition, HPV DNA host integration at fragile sites, which are more susceptible to strand breakage 
and chromosomal aberrations and instabilities, may favor the epithelial oncogenic process due to stress or viral reactivation [269]. Apart from toxic exposition (UV light, smoke), the risk of triggering HPV reactivation is also associated with pregnancy (Table 3).

\section{- Pregnancy}

The persistence of genital warts from past HPV infections appears to be associated with a high risk in women for progressing to cervical cancer over several decades $[264,270]$. In pregnancy, HPV-16 reactivation increases the risk of tumor development during pregnancy, such as through hydatidiform moles. Pregnancy-induced HPV reactivation is one way in which the newborn can become infected with HPV without involving reinfection of the mother, including through possible sexual transmission from a partner [271,272]. The $\mathrm{HPV}$ vertical transmission mode from the mother to the infant could be a result of various propositions, i.e., periconceptual (fertilization), prenatal (transplacental hematogenous transmission or ascending infection), or perinatal (delivery) [273-275]. HPV transmission rates are estimated to be between $18.2 \%$ and $53.3 \%$ for all trimesters [271,272]. Indeed, HPV-16 DNA in syncytiotrophoblast cells was detected in $29 \%$ of the samples collected from a spontaneous abortion group [264]. During pregnancy, HPV16 infection promotes Th2 cytokine dominance at the fetal-placental interface by stimulating IL-5, IL-10, and IL-17A expression, which extends to the newborn's system, persisting after birth for at least several months $[271,276]$. As this persistence in the newborn's system can last for at least several months after birth, the HPV16-induced Th2 profile may impact on the postpartum HPV-specific immune response to a subsequent HPV encounter, may influence latent form establishment, and may predispose children to developing HPV lymphoma at a later age $[271,272,277]$. In addition, this phenomenon might mirror the familial tendency to develop HPV-related cancers. This HPV-induced Th2 profile of prenatal memorization/prolongation is opposed antiviral Th1 maturation, increasing the vulnerability for others genital infections [271,272]. In turn, pathogens responsible for surrounding genital warts (i.e., HSV-2) are potential triggers for HPV reactivation. EBV, HBV, HCV, HSV-2, and B19V are detected in HPV-positive tumors [148]. Although not being significantly associated with a cancerogenesis cervix, the seropositivity against these multiple infections increases the relative risk of developing HPV-16 cervical cancer $[148,278]$. Several epidemiological and experimental studies support the idea of the mechanisms by which viral cofactors might contribute to HPV tumorigenesis (Guidry's review offers a well-detailed account), namely EBV-enhanced HPV genomic instability [148], HSV-2 "hit-and-run" HPV oncogenesis [148,279,280], and HHV-6-limited HPV clearance [278]. The cooperation depends on the endemic area. In South America, the higher risk of HIV/HPV coinfection leading to cervical cancer is a particular concern because of its young population [281]. Epidemiological studies have published a prevalence rate of $28.4 \%$ for high-risk types of HPV infection (HR-HPV) in (+) HIV Brazilian women [282]. Another investigation in the south of Brazil confirmed the high prevalence of HIV-HPV coinfection (40,8\%) compared to HCV $(10.8 \%)$ and HBV (2.3\%). Furthermore, high-grade intraepithelial lesions or in situ carcinoma were found in $52(9 \%)$ of the coinfected cases [281]. Moreover, in a Brazilian (+) HIV pregnant study, the presence of high-risk types (HPV-16/18) in $79.8 \%$ of samples with multiple infections in $16.3 \%$ of cases was discovered [283].

- $\quad$ ZIKV /HPV coinfection and pregnancy

During the ZIKV outbreak in Guayaquil, Ecuador, the same number of positive results between ZIKV (+5) and HPV (+5) ("pap smear") with RNA cervical detection were found in 19 samples of atypical squamous cells of undetermined significance (ASCUS) [97]. Even in the absence of a coinfection context here, this prime investigation highlights the need to be aware of (1) the possible merge in etiology between HPV and ZIKV, (2) the risks of ZIKV-induced reactivation in mothers with HPV genital warts leading to cancerogenesis, and (3) the uncertain pregnancy outcomes in an HPV / ZIKV co-exposition context, especially when there are asymptomatic (mother) patients and/or considering the HPV latent form $[97,284,285]$. An HPV-infected mother may change her placental 
resistance immune profile to promote ZIKV crossing earlier, for longer, and in greater amounts, leading to in utero fetal damage or CZS. ZIKV, in turn, could be a triggering cofactor for HPV oncogenesis, which dramatically affects well-being during childbearing as well as making infants more susceptible to developing non-communicable diseases and tumors later in life, even in the absence of evidence of direct viral transmission [148]. From one cohort study, the results demonstrated that, rather than being detected at birth, manifestations of CZS may appear during the first year of life [57,286].

The overlap between high HPV seroprevalence groups and the area of CZS emergence is far from indicative of a problem in South America and in particular population clusters [287-290]. This encourages research to fill the current gaps in literature concerning the epidemiology of the frequency of ZIKV / HPV co-exposition by gender, localization, and other socioeconomic factors to uncover evidence of possible HPV / ZIKV syndemism. The association between the high prevalence of oncogenic HPV and high-risk strains might be verified and/or completely revisited from arguments for the coinfection influence in the HPV carcinogenesis.

Studies on the influence of co-viral infections on ZIKV epidemiology and pathogenicity, as well as on human immunity and health, are ongoing. To date, as direct evidence is lacking, the proposed contribution of HLV coinfections to ZIKV outcomes is only based on speculation. However, this section shows that some HLV biological system features may also overlap with those of ZIKV and influence its viral replication, tropism, pathogenicity, and epidemiology parameters (Figure 4). Therefore, the reciprocal is also true as following describing (Figure 5).

\section{The Influences of ZIKV Infection on Human Latent Virus (HLV) Outcomes in the Host}

Human latent virus refers to one category of persistent pathogens in humans (Figures A1 and A2), in which the maintenance and control mechanisms may be completely changed in the context of a recent ZIKV infection with consequences on latent virus and host reservoirs. Figure 5 argues on this. The followed sections (from Sections 3.1-3.5) support and provide additional explanations to Figure 5.

\subsection{ZIKV and HSV-2}

ZIKV may play an important role in the HSV outcome by unbalancing the vaginal flora and by promoting recurrent genital warts, sexual transmission, and HSV-related congenital infection (Figure 5). To date, little evidence has been provided regarding ZIKV-induced reactivation of latent viruses, apart from a case of encephalitis in a Brazilian child with ZIKV infection that was related to VZV reactivation in the central nervous system [291]. This lack of data needs to be addressed by designing experimental models such as ZIKV/HSVs coinfection systems that allow the molecular mechanisms to be described and to investigate some potential cooperative signaling pathways associated with changes in tropism as well as in transmission and in the congenital and neurological pathogenicity of both viruses (ZIKV and HSV-1/2) (Figures 5 and 6) [292]. 'Combination (two-in-one) therapy' is still considered an appropriate and encouraging technique, as mentioned in Section 2.

\subsection{ZIKV and HHV-6}

In contrast to HSV-2, HHV-6 shows ubiquitous distribution in humans, suggesting a large diversity in susceptible human cells. Therefore, ZIKV infection may drive HHV-6 concentrations in particular compartments, such as immune privileged organs (e.g., the testes and brain). To date, the consequences of HHV-6 infection on human health (e.g., diseases and comorbidities) remain underexplored, including in vulnerable populations. In pregnant woman ((+) HHV-6A), ZIKV infection could facilitate HHV-6 vertical transmission by reducing the barrier integrity (e.g., placental injuries) and contribute to maintenance of the postnatal neonatal immunodepressive mechanisms by promoting HHV-6-linked Th2 cytokine dominance. In addition, ZIKV can promote the emergence of non-communicable diseases (NCDs) and HHV-6-related infant diseases at later ages (e.g., in telomere diseases). 
Overall, this encourages the design of future studies that include population genetics as a (causal) factor in ZIKV-linked microcephaly. A particular interest in HHV-6(+) clusters coinfected with ZIKV and, ideally, in pregnant woman may potentially show changes in causal links. ZIKV could be victim to false accusations and may only be partially responsible for HHV-6 reactivity, the true responsible party for congenital effects.

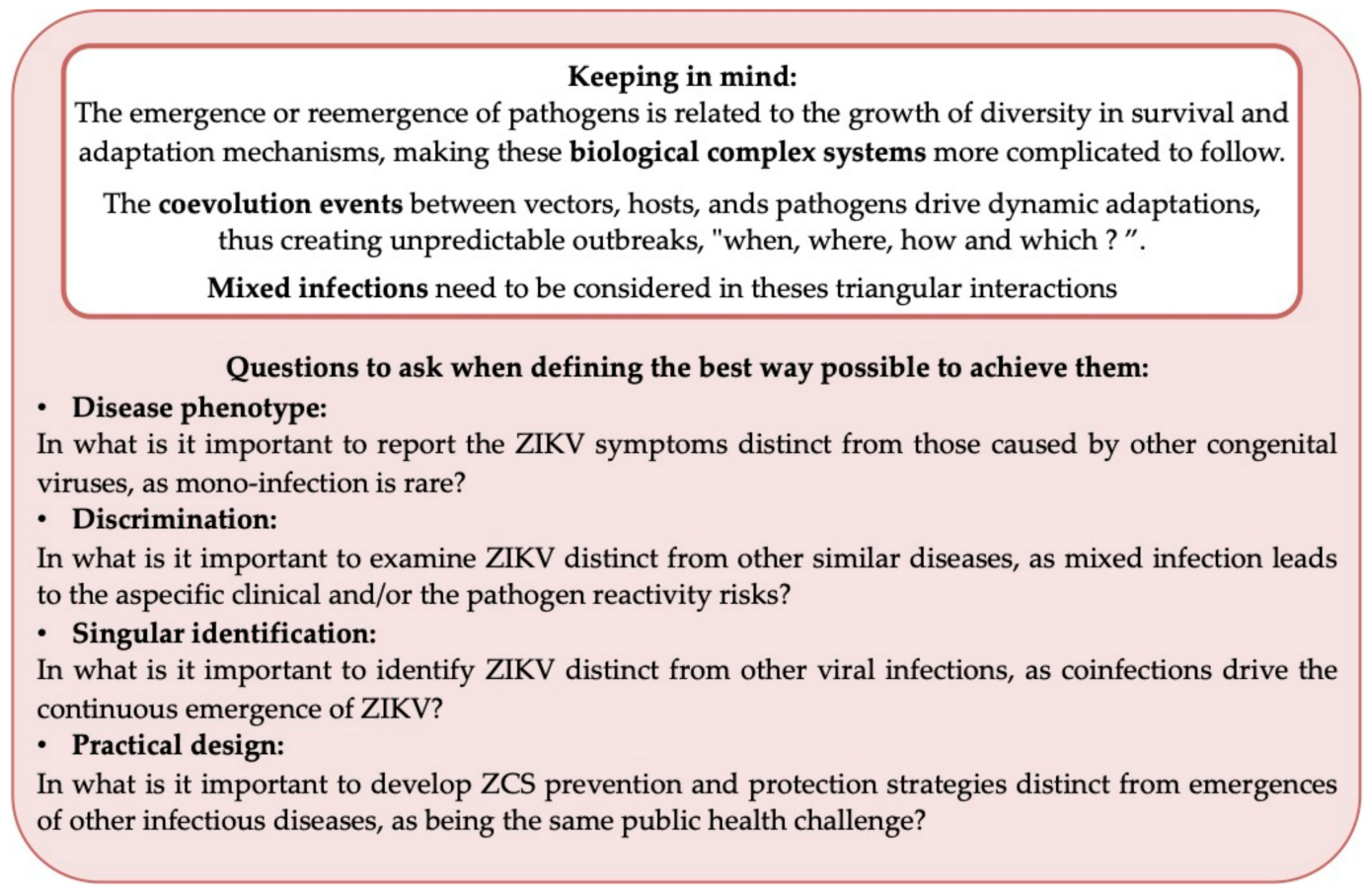

Figure 6. Important considerations for future latency-related CZS research investigations.

\subsection{ZIKV and EBV}

EBV is ubiquitous in human populations, which makes its coinfection with other pathogens common and not unusual with ZIKV (Chapter 2). EBV latency is characterized by a multiplicity of persistent types in (Figure A2). This diversity may originate from the various cointeractions with different viruses, which involve coevolution mechanisms in some niches. As per other pathogens coinfected with EBV, ZIKV represents a determinant of EBV reactivation. It can also control the EBV cellular invasion level, the infected B cell pool, and their relocalization. However, to date, no common pathway has been elucidated. Although being a sufficient factor to cause oncogenesis, ZIKV may exert pressure on the selection of some variants, mirroring a growth in the adaptation and possible oncogenesis of EBV depending on the host. Pregnancy is a particularly vulnerable period in which EBV / ZIKV coinfections show dual risks in terms of the outcome of the pregnancy (fetal development) as well as in terms of the mother's health in relation to EBV tumorigenesis. While EBV/ZIKV coinfection may affect well-being during childbearing, it also raises questions about the consequences of asymptomatic forms and how to investigate such scenarios.

\subsection{ZIKV and B19V}

Despite differences in the nature of its genome (e.g., DNA vs. RNA), B19V shows as strong a susceptibility as ZIKV to mutation. As such, ZIKV coinfection is an opportunity for B19V viral genome evolution, resulting in growth in its adaptation to the host and possibly in virulence. B19 pathogenicity is related to oxygen-dependent organs such as the placenta and brain. Compared to HHV-6, B19V is closer to TORCH groups, including ZIKV. Pregnancy and ZIKV are both triggering factors for B19 reactivation. As placental development and fetal growth are particularly oxygen-demanding, the second trimester 
is a vulnerable period for B19V infection, in which ZIKV may dramatically exacerbate congenital effects (e.g., placental injuries and hydrops), embryopathies, abortion, and stillbirth. In view of the seroprevalence of B19V increasing in the latest ZIKV outbreak in Brazil, a full review of some of the studies on ZIKV pathogenicity in B19V endemic regions might lead us to reconsider $\mathrm{B} 19 \mathrm{~V}$ as a direct cause of congenital effects rather than a cofactor of ZIKV.

\subsection{ZIKV and HPV}

HPV infection in humans shows an evolution closely related to the female urogenital tract compared to the other latent viruses reviewed here. Despite being defined as a latent virus, $\mathrm{HPV}$ reactivation from superinfection, such as with ZIKV, may dramatically affect the reproductive life of a woman. While some subtypes (e.g., HPV-16/18) are always responsible for all cases of cervical cancer, ZIKV coinfection with HPV can promote the malignancy of other subtypes (expanding the panel of malignant HPVs) as well as the frequency of tumorigenesis by creating a stress environment. By acting as a trigger, ZIKV may, at the same time, highlight a familial predisposition of HPV-linked cancers which may help in better understanding and management of them, similar to B19V or HHV-6 above. Currently recommended in young adulthood, the consequences of the HPV vaccine prior to ZIKV infection have to be investigated regarding the risks of vaccine inefficacy, particularly in uncontrolled HPV reactivation.

At this stage of review, the contribution of HLV to the re-emergence of ZIKV with congenital syndrome development could result from (1) the transmission of HLV function to ZIKV, improving its outcome in humans and its dominance in the host biological systems, and/or (2) the establishment of cooperation or confrontation systems, even temporarily (partially), suggesting the persistent benefits of ZIKV to HLVs. As described here, ZIKV interactions with HLV may correspond to triggering events (reactivation) and also to altering (interference) or creating benefits (accommodation) for the replication of both. The resulting heterologous immunity of mixed infections is mostly negative for human health (pathogenicity), but the possibility of the opposite effect (positive) needs to be kept in mind (i.e., ZIKV coinfection benefit in host microbiota health) (Figure 5).

The coevolution between viruses and hosts prompts consideration regarding the inclusion of additional variables, including the field. As mentioned in Chapter 1 , several other factors influence or drive the cooperation and/or competition of evolution in humans, including the environment, socioeconomic status, host, and lifestyle (Figures 3-5). The latter can provide clues for mapping, describing, and classifying the opportunities of coinfection. These take an important place as decision-making tools regarding the future challenges of coinfections or, more broadly, mixed infections with endemic area biodiversity and vulnerable populations (e.g., mothers and infants).

\section{Update of the ZIKV Congenital Infection Technical and Control Guidance in the HLV Coinfection Context}

This title led us to revisit the ZIKV Action Plan: (1) exhaustive and powerful diagnostics, (2) suitable mother and infant management, (3) ZIKV vaccination, (4) redesign of other preventive plans, (6) environmental surveillance with respect to biodiversity, and (7) the development of epidemiological and experimental models. As an introduction, Figure 6 proposes (or lists) some opening questions to support the next useful investigations into CZS (Figure 6).

\subsection{Perspectives for Diagnoses}

Despite efforts to perform screening surveys to define a seroconversion range (between $1 \%$ and $50 \%$ in the population) for potential vaccine implementation, the seroprevalence of ZIKV infection in endemic countries remains unknown, with even less known regarding ZIKV coinfections. In addition, the search for secondary causes or the detection of other pathogens contributing to the clinical manifestations and disease progression has been far from systematic, in particular, with regard to an outbreak situation. 
In fact, this state of mind is reflected in the current availability of diagnostic assays showing high specificity and, thus, glossing over the relevant supplemental pathogens. The matter of coinfection in arbovirus diagnosis, including ZIKV, is already a subject of discussion, with the risk of misdiagnosis and unsuitable patient management procedures $[52,58,96,104,250,293-296]$. Therefore, this is more often an issue of the performance of the detection tool (sensitivity and specificity) rather than the contribution of other pathogens to disease severity. Unfortunately, the usefulness of systematic and exhaustive diagnosis in the management of pregnant women (e.g., education and treatment) according to the sequence coinfections, including congenital and arboviral viruses, is already being questioned in some studies $[58,104,250,296]$. Drawing up a list of potential etiological agents to screen is the next challenge, during which seroprevalence studies need to be considered by firstly focusing on some urban areas associated with particular socioeconomic patterns and sex behaviors in arbovirus endemic regions $[52,58,104,250,296]$. In light of this review, the maternal coexposure to the latent virus showing urogenital tropism in human organisms, such as HSV-2, HHV-6, EBV, B19V, and HPV with ZIKV, needs to be taken into account. Instead of determining a unique etiology of diseases, the importance of co-exposition in the evolution of pathogenesis needs more scientific and social attention to answer ZIKV infection-related questions. CZS calls for a new diagnostic concept open to multiple etiological definitions [297]. If so, toward which diagnosis tools should the scientific community turn to overcome technical limitations? As mentioned above, coinfections often result in limited sensibility and sensitivity (false negative and positive results). Apart from their etiological cause, the presence of a second pathogen can influence the viral load and limit virus isolation and culture in suitable cell models. In view of the various levels of contribution of pathogens to disease outcomes, the design of tools allowing prioritization may help management, provided data are used properly and can be extrapolated easily. Mixed infections generate heterologous responses of the host immunity and metabolism. Therefore, both laboratory and field work will be necessary to continue developing cutting-edge diagnosis tools by, in particular, thinking about new molecular determinants (e.g., genomes, proteins, and metabolites, their conjugated detection, and the nature of the sample (e.g., blood, urine, saliva). HLV participation in CZS also highlights the need for an in-depth discussion of the management of expectant mothers.

\subsection{Treatment and Management}

The re-emergence of ZIKV, despite the development of congenital diseases still being subject to much controversy in the literature, should lead to regular updates of the relevant pregnancy guidelines. Regarding the hypothesis that the evolution of ZIKV pathogenicity results from opportunistic interplay with HLV rather than new acquisitions, this may result in dramatic recasting of the current CZS management strategies through first targeting latent viruses. In other words, the control of and cure for latency infections may prevent, protect from, and limit the emergence of CZS and other types of ZIKV pathogenicities. In contrast to acute infectious diseases, the measures to eradicate the persistent viruses themselves are still facing challenges.

Apart from improving clinical symptoms and limiting the frequency of recurrence, antiviral strategies have to avoid maintaining virus latency in hosts by continuously focusing on its evolution (RNA genome), its growth in diversity (variant selection), and/or possible superinfection-induced reactivation.

Recent advances in CRISPR/Cas9 genome editing allow for the proposal of cuttingedge strategies for selectively targeting latent viruses by deleting or mutating specific latent virus DNA regions [298]. For example, the use of pharmacological inhibitors of histone demethylase to promote the epigenetic suppression of viral genomes shows a "locking in latency" system for HSV $[299,300]$. In the same way, certain drugs may allow to release latent viruses and to promote lytic infections as a "lytic therapy" system, as opposed to the former systems [301]. Some of the available antiviral drugs and adjuvants have already shown promise in lytic virus reactivation [142,143]. Using bacteriophage to block 
reactivation or to promote lysogenic is proposed via a vaccine concept, Acyclovir R430 [302]. Besides targeting latent viruses, treatment combinations should also be proposed, such as antiviral molecular drugs for ZIKV and an immunomodulatory compound for latent viruses. Nevertheless, the heterologous response features of coinfections bring some limitations and risks of inefficiency or exacerbating the immune system, as per common cytokine storms [49]. Such an immune host response is currently at the heart of COVID-19 pathogenesis, for which a preventive approach is a public health priority. This also raises the challenge of vaccine design for ZIKV with co-circulation, co-exposition, and coinfection risks in some biodiversity areas to achieve true efficacy.

\subsection{Vaccine}

The development of a ZIKV vaccine remains a priority. The DENV/ZIKV crossreactivity preventive effect (the idea that prior DENV infection could provide a protective effect in endemic arbovirus areas) is one of the possible research avenues. However, the risk of DENV antibody production driving antibody-dependent enhancement (ADE) of ZIKV replication has also been characterized, without forgetting the uncertain efficacy of a vaccine to prevent multi-exposition risk, such as DENV, ZIKV, and CHIKV. Therefore, the challenge is to design a vaccine by avoiding (limiting) cross-reactive epitopes, attrition, and depletion or displacement of memory CD8 T cells [49]. Determining the outcome of vaccinations in heterologous infections and ensuring the safety and efficiency are key requirements for the development of any vaccine.

The development of a vaccine based on the concept of the measles vaccine, i.e., providing protection against other unrelated infections, is ongoing [303,304]. In general, the administering of two potential vaccines for endemic areas are proposed: one administered during the outbreak with a vaccination program targeting women of reproductive age to prevent in utero infection, and the other during an inte-epidemic period with a broad-based vaccination campaign targeting the general population to establish population immunity. By contrast, the implementation of a vaccine/treatment to pregnant women remains a dilemma in monoinfections, as well as in mixed infections. In fact, rather than questioning, here, the complexity, necessity, and efficiency of a vaccine design, the complexity of the ZIKV biological system and, especially, of the syndemics process, encourages the preparation of a global and multidisciplinary plan that takes into consideration the risk determinants in CZS emergence and epicenter generation.

\subsection{Prevention and Primary Healthcare}

Despite the severity in congenital outcomes, pregnant women are not differently affected by ZIKV compared to the general population. The non-specific, or worse, the asymptomatic forms in pregnancy highlight the need for greater efforts to implement preventive strategies. Besides the vaccine program, other priorities should be resolved beforehand, including primary healthcare and improving the sanitary conditions of populations. From the perspective of congenital and arbovirus protective advice, the guidelines and education (e.g., sex and hygiene) need to be rethought in terms of the nature and opportunities (frequency) of coinfections in association with congenital risks. The overlapping between the risks area to contract diseases and the CZS emergence epicenter defines an emergency zone. In Rio de Janeiro, $41 \%$ of pregnant women infected with arboviruses and other infections lived in urban slums, mostly in Niterói; surprisingly, no coinfections with arboviruses were detected [305].

Environmental factors (e.g., climate), housing conditions, nutrition, and healthcare access as well as behavior regarding the risk of contracting infectious diseases (e.g., sexual activity or outdoor activities (bites from a mosquito), have a combined impact on immune status, without forgetting the genetic background of a person, such as their syndemic image $[84,119,120,306]$.

As a consequence, the acquisition sequence of a mixed infection and its effects on health are unique to each person. All of these factors contribute to a mosaic of response pro- 
files to ZIKV infection in pregnancy between mothers (e.g., symptomatic or asymptomatic, phenotypes, disease progression, and later outcome in infants). While the emergence of ZIKV is a global concern, CZS management still remains singular to individual mothers.

\subsection{Environmental Surveillance}

The climate impacts biological systems [83]; it has differential effects on the surrounding landscapes and shapes urban and rural areas. It also influences the life cycle of pathogens (e.g., replication and temperature), vector ecology (e.g., food behavior and habitats), and the health of different populations (e.g., vulnerability, hygiene, and food access) [122].

In a same region, the climate is included in the definition of the immune profiles of the local populations, as well as in the moving of coinfection opportunities of ZIKV during pregnancy. Therefore, environmental change may be an important sensitive marker of the emergence of infectious disease outbreaks, and also of the risk of coinfections, highlighting the necessity of more monitoring systems linking such environmental changes with the emergence of infectious diseases (EID), and of rethinking, as of now, the concept for future studies.

\subsection{New Experimental Study Designs for Better Understanding and Preparing for the Future}

As described above, several strategies are used to counteract the antiviral host cell process that promotes viral persistence and survival by suitably facilitating reactivation. Moreover, certain common threads of the latency mechanisms appear among human viruses, which is proof of the long-term evolutionary relationships that exist between host organisms and this new viral invader.

The characterization of the common mechanisms involved in latent coinfections with ZIKV is key to developing suitable prevention strategies for prior and/or during pregnancy, thus limiting the risk of CZS. For this, models need to be designed to reproduce co-viral infections and environments.

Thus far, mathematical models of viral coinfections have already been developed for $\mathrm{HIV} / \mathrm{HCV}$ coinfection, allowing for the determination of risk factors (e.g., human activity), to evaluate antiviral drug combinations, predict disease progression and, possibly, to elucidate drug resistance as a result of viral genome coevolution [49]. Even if this offers wide opportunities for concepts to study several determinants and interactions, a better understanding of the molecular and cellular processes controlling viral latency in ZIKV infection cannot be accurately addressed using these mathematical models.

Several types of persistent infections can already be reproduced in cell culture systems depending on viral latent forms (e.g., chronic focal infections, chronic diffuse infections, and true latent infections) [131]. Interestingly, an induced pluripotent stem cell-derived (iPSC-derived) myeloid lineage model of herpes virus latency has been proposed as a potential support for studying ZIKV [307].

Nevertheless, the establishment and maintenance of latency depends on tissue microenvironments and often cannot be recapitulated in cell culture. As a consequence, complex tissue culture models are presumably required to replicate some aspects of viral latency. For example, HSV1 latency can be modeled in primary rat neurons treated with nerve growth factor (NGF), which maintains progenitor neuronal cell survival and prevents viral lytic cycle gene expression [308]. This could be suitable in a ZIKV/HSV coinfection model for understanding the observed neurotropism and neuropathogenicity in adults as well as in fetal development $[142,143]$.

Following this, the contribution of coinfections to the outcome of diseases as compared to monoinfections needs support from studies using physiological (animal) models. Such physiological systems should help us to better understand the enigmatic outcome of ZIKV infection in twin pregnancies [309].

In addition to the confounding clinical signs, multiple misdiagnosis opportunities, unsuitable management, and cures with others viral congenital pathogens, the experimental 
evidence takes us even further away from claiming a causal link between ZIKV and microcephaly, and wrongly so.

In addition to genetic evolution studies, omics tools (e.g., transcriptomics and proteomics) may allow to deepen our understanding of the effects of coinfections on host physiological, endocrine, and immune response changes. Metabolomic and lipidomics will occupy a major place in the future diagnostic tools for investigating arboviruses (e.g., ZIKV) and could be the next field of ZIKV / latent virus coinfection research (e.g., physiopathology studies, diagnostics, and treatment) [310].

These last challenges call upon to firstly review of the perspectives in terms of biodiversity awareness and respect.

\section{General Conclusions and Perspectives}

The Brazilian ZIKV outbreak marks a strong comeback of vector-borne pathogens to the forefront of the international arena. In summary, CZS mirrors a long virus evolution built along three major periods with potential overlap: (1) Historically, the definition of ZIKV was glued to the classical definition of arbovirus as a non-threatening infection, but with the potential for emergence (e.g., in Micronesia and, specifically, Yap) (Figure 1). The ZIKV life cycle is balanced between anthropophilic Aedes aegypti (the vector) and opportunistic urban humans (the host), allowing occasional meetings with other vertebrate pathogens, such as persistent and/or congenital viruses whose genomes are mostly DNA (Figure 3 and Table 1). (2) The current state of globalization generates vector/human promiscuity, resulting in the intensification and increase in the frequency of ZIKV human infections. This context leads to humans being a suitable host for ZIKV, with adaptations in the viral replication, the immune dialogue, and the pathogenicity outcome (Figure 4). The heterogeneous behavior of populations provides a mosaic of opportunities for parallel evolution (coevolution) with latent/congenital viruses in humans, from which it obtains new properties, e.g., persistent and possible sexual transmission and congenital tropism. Thus, could we be speaking of a human reservoir and a true congenital pathogen? (3) Humans are already a reservoir of congenital viruses, meaning mostly persistent viruses with the potential for reactivation. Latent viruses show uniqueness in a persistent process in which the viral genome remains dormant in cells throughout the host lifetime.

Their reactivation and subsequent triggering of lytic replication leads to large amounts of viral progeny that can be transmitted to new hosts, such as from mother to fetus in pregnancy, without new external reinfections. The physiological changes in pregnancy may trigger reactivation of latent viruses as well as infection by another virus. ZIKV infection in pregnancy provides a dual effect: both reactivation and co-exposition opportunities for latent viruses (Figure 5). In turn, the viral lytic cycle mechanism causes biochemical, cellular, immune, and physiologic process disorders in women, which results in a fatal outcome for fetal development, overall, in a ZIKV (co)infected mother context. Microcephaly is commonly the clinical key between congenital pathogens.

Ubiquitous in human compartments, the persistent viruses described here result in the acquisition of a large spectrum of Congenital ZIKV Syndrome, clinical signs, and disease progressions, all shaped by host response.

As a consequence, should the next direction of the evolution of ZIKV be to determine a latent virus image with inter-human dissemination and a strict life cycle in vertebrates (e.g., transmission, replication, and persistence) with the expansion of genome diversity? If so, what about the upcoming (future) pathogenesis phenotypes? Where, when, and how? Perhaps a better answer refers to the past: Where did ZIKV come from?

ZIKV is thought to be a zoonotic virus from an as-yet-uncertain animal reservoir (zoonosis). Studies on coinfections in wildlife need to be performed and questions must be asked about their viral latency contribution to the emergence of viral diseases.

The growing complexity of systems is a key pattern for viral adaptation, and, thus, is unpredictable, but against which it is possible to prepare, protect, limit, and control effects. 
To this end, "One Health" research needs to be reinforced from the epidemiological, clinical, and experimental perspectives. Apart from the matter of arboviruses, scientific efforts are also helpful for fighting other currently emerging fatal viruses, such as fever hemorrhagic Ebola virus in Africa and COVID-19 worldwide. The global increase in COVID-19 incidence with atypical clinical manifestations and even fatalities, though worse in extent, call to mind the prior ZIKV scenario in Brazil. Then, what is the impact of latent viruses on the pathogenicity of COVID-19 and on its global and continuous emergence?

Funding: This research received no external funding.

Institutional Review Board Statement: Not applicable.

Informed Consent Statement: Not applicable.

Data Availability Statement: Not applicable.

Conflicts of Interest: The author declares no conflict of interest. 


\section{Appendix A. Definitions Section}

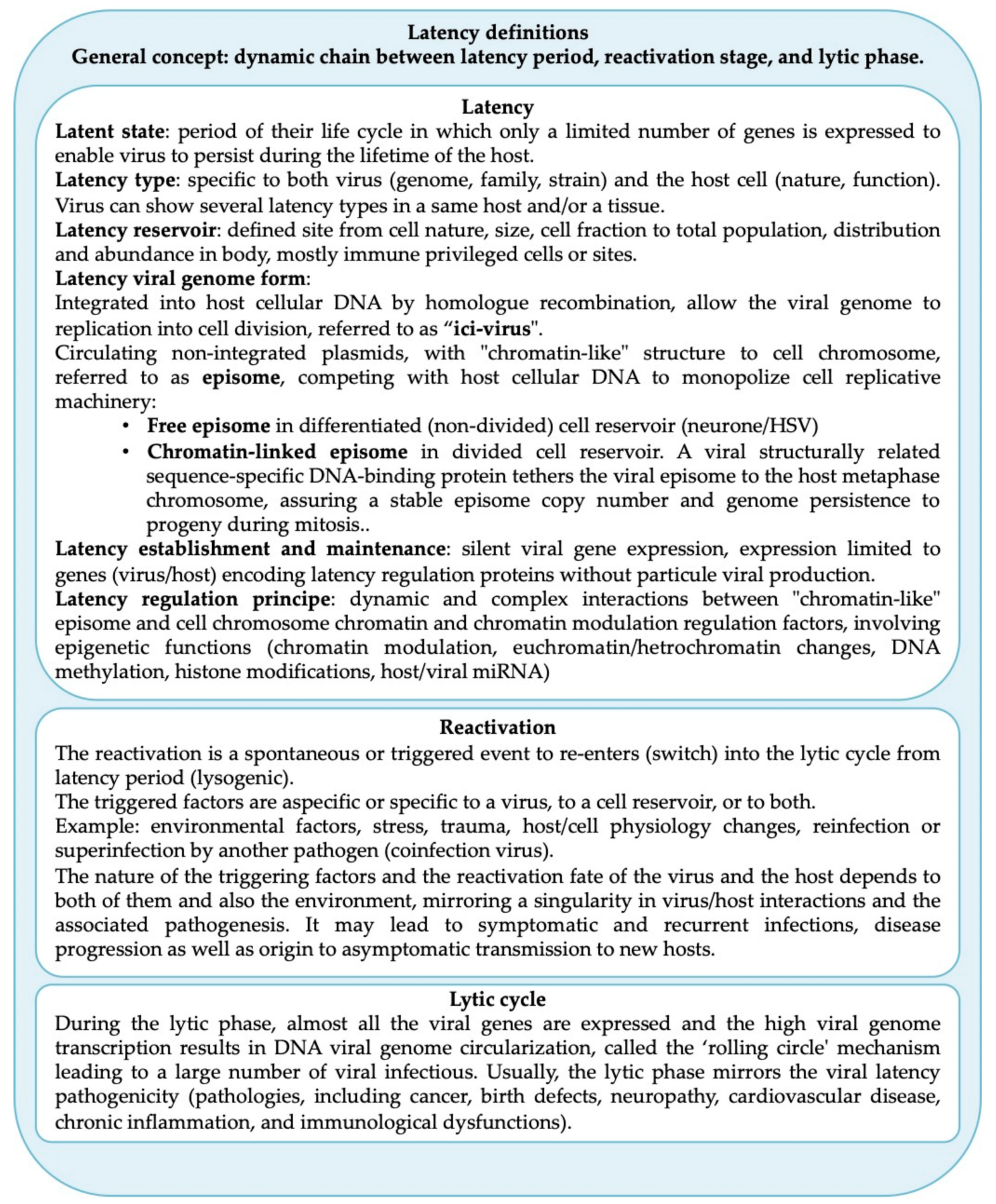

Figure A1. The latency cycle is based on three major steps: latency, reactivation, and the lytic phase. The characterization of viral latency includes the state, type of reservoir, form, establishment, and regulation. 


\section{Persistent definitions}

Persistent virus: virus infecting specific cell types of one or more tissues or organs in which it remains and is not cleared.

Persistent mechanism: viral and cellular gene expression changes (silent, slow down) and host immune response controls (escape, recognition, quick internalization, antigen variation).

Persistent infection: silent phase or "soft" replication with possible switch to active viral production stage or lytic cycle.

Pathogenic persistent: mechanisms by which active virus replication in cells leads to cytolytic, tissue injuries (pathogenic) and possibly causes diseases (endocrinal, metabolic, immune disorders).

Persistent types (categories): latency, chronicity and slow-down infection, which involve distinct and continue virus-host cell interactions with possible similitudes.

- Latency: reversible non-productive infectious state (different to no abortive lytic infection) involving dynamic interactions in metastable equilibrium with host antiviral immunity, and with ability to switch into lytic cycle by reactivating viral particules reservoir: neither innocuous nor inert state (e.g. HSV-2).

- Chronicity: continue infectious virus production state with host immunological imbalancing causing cell and tissue disorders, resulting in diseases (e.g. HCV).

- Slowdown: asymptomatic and progressive state from a long incubation period to disease over months and years, without acute viral multiplication (asymptomatic primary infection), but still progressing to death. It is usually related to genetic predisposition or to immunological, hematological depressive state, changing viral latency (e.g. HIV).

Figure A2. Persistent definitions of intracellular pathogens.

\section{References}

1. Duffy, M.R.; Chen, T.H.; Hancock, W.T.; Powers, A.M.; Kool, J.L.; Lanciotti, R.S.; Pretrick, M.; Marfel, M.; Holzbauer, S.; Dubray, C.; et al. Zika virus outbreak on Yap Island, Federated States of Micronesia. N. Engl. J. Med. 2009, 360, 253-2543. [CrossRef]

2. Baud, D.; Gubler, D.J.; Schaub, B.; Lanteri, M.C.; Musso, D. An update on Zika virus infection. Lancet 2017, 390, 2099-2109. [CrossRef]

3. Gubler, D.J.; Vasilakis, N.; Musso, D. History and Emergence of Zika Virus. J. Infect. Dis. 2017, 216, S860-S867. [CrossRef]

4. Wikan, N.; Smith, D.R. Zika virus from a Southeast Asian perspective. Asian Pac. J. Trop. Med. 2017, 10, 1-5. [CrossRef] [PubMed]

5. Weaver, S.C. Emergence of Epidemic Zika Virus Transmission and Congenital Zika Syndrome: Are Recently Evolved Traits to Blame? mBio 2017, 8, e02063-16. [CrossRef]

6. Aubry, M.; Teissier, A.; Huart, M.; Merceron, S.; Vanhomwegen, J.; Roche, C.; Vial, A.L.; Teururai, S.; Sicard, S.; Paulous, S.; et al. Zika Virus Seroprevalence, French Polynesia, 2014-2015. Emerg. Infect. Dis. 2017, 23, 669-672. [CrossRef]

7. Driggers, R.W.; Ho, C.Y.; Korhonen, E.M.; Kuivanen, S.; Jaaskelainen, A.J.; Smura, T.; Rosenberg, A.; Hill, D.A.; DeBiasi, R.L.; Vezina, G.; et al. Zika Virus Infection with Prolonged Maternal Viremia and Fetal Brain Abnormalities. N. Engl. J. Med. 2016, 374, 2142-2151. [CrossRef]

8. Martines, R.B.; Bhatnagar, J.; de Oliveira Ramos, A.M.; Davi, H.P.; Iglezias, S.D.; Kanamura, C.T.; Keating, M.K.; Hale, G.; Silva-Flannery, L.; Muehlenbachs, A.; et al. Pathology of congenital Zika syndrome in Brazil: A case series. Lancet 2016, 388, 898-904. [CrossRef]

9. Martines, R.B.; Bhatnagar, J.; Keating, M.K.; Silva-Flannery, L.; Muehlenbachs, A.; Gary, J.; Goldsmith, C.; Hale, G.; Ritter, J.; Rollin, D.; et al. Notes from the Field: Evidence of Zika Virus Infection in Brain and Placental Tissues from Two Congenitally Infected Newborns and Two Fetal Losses-Brazil, 2015. MMWR Morb. Mortal. Wkly. Rep. 2016, 65, 159-160. [CrossRef]

10. Schuler-Faccini, L.; Ribeiro, E.M.; Feitosa, I.M.; Horovitz, D.D.; Cavalcanti, D.P.; Pessoa, A.; Doriqui, M.J.; Neri, J.I.; Neto, J.M.; Wanderley, H.Y.; et al. Possible Association Between Zika Virus Infection and Microcephaly-Brazil, 2015. MMWR Morb. Mortal. Wkly. Rep. 2016, 65, 59-62. [CrossRef]

11. De Carvalho, N.S.; De Carvalho, B.F.; Fugaca, C.A.; Doris, B.; Biscaia, E.S. Zika virus infection during pregnancy and microcephaly occurrence: A review of literature and Brazilian data. Braz. J. Infect. Dis. 2016, 20, 282-289. [CrossRef]

12. Wang, J.Z.; Guo, X.H.; Xu, D.G. Anatomical, animal, and cellular evidence for Zika-induced pathogenesis of fetal microcephaly. Brain Dev. 2017, 39, 294-297. [CrossRef]

13. Britt, W.J. Adverse outcomes of pregnancy-associated Zika virus infection. Semin. Perinatol. 2018, 42, 155-167. [CrossRef]

14. Krauer, F.; Riesen, M.; Reveiz, L.; Oladapo, O.T.; Martinez-Vega, R.; Porgo, T.V.; Haefliger, A.; Broutet, N.J.; Low, N.; WHO Zika Causality Working Group. Zika Virus Infection as a Cause of Congenital Brain Abnormalities and Guillain-Barre Syndrome: Systematic Review. PLoS Med. 2017, 14, e1002203. [CrossRef]

15. De Araujo, T.V.B.; Rodrigues, L.C.; de Alencar Ximenes, R.A.; de Barros Miranda-Filho, D.; Montarroyos, U.R.; de Melo, A.P.L.; Valongueiro, S.; de Albuquerque, M.; Souza, W.V.; Braga, C.; et al. Association between Zika virus infection and microcephaly in Brazil, January to May, 2016: Preliminary report of a case-control study. Lancet Infect. Dis. 2016, 16, 1356-1363. [CrossRef] 
16. Trigueiro, S.A.; Neves, B.F.; Aguiar, M.S.B.; Araujo, J.S.S. Correlation between cephalic circumference at birth and ocular alterations in patients with microcephaly potentially associated with Zika Virus infection. Rev. Assoc. Med. Bras. (1992) 2019, 65, 909-913. [CrossRef]

17. Mlakar, J.; Korva, M.; Tul, N.; Popovic, M.; Poljsak-Prijatelj, M.; Mraz, J.; Kolenc, M.; Resman Rus, K.; Vesnaver Vipotnik, T.; Fabjan Vodusek, V.; et al. Zika Virus Associated with Microcephaly. N. Engl. J. Med. 2016, 374, 951-958. [CrossRef]

18. Schwartz, D.A. Autopsy and Postmortem Studies Are Concordant: Pathology of Zika Virus Infection Is Neurotropic in Fetuses and Infants with Microcephaly Following Transplacental Transmission. Arch. Pathol. Lab. Med. 2017, 141, 68-72. [CrossRef]

19. Pool, K.L.; Adachi, K.; Karnezis, S.; Salamon, N.; Romero, T.; Nielsen-Saines, K.; Pone, S.; Boechat, M.; Aibe, M.; Gomes da Silva, T.; et al. Association Between Neonatal Neuroimaging and Clinical Outcomes in Zika-Exposed Infants from Rio de Janeiro, Brazil. JAMA Netw. Open 2019, 2, e198124. [CrossRef]

20. De Souza, A.S.; de Oliveira-Szjenfeld, P.S.; de Oliveira Melo, A.S.; de Souza, L.A.M.; Batista, A.G.M.; Tovar-Moll, F. Imaging findings in congenital Zika virus infection syndrome: An update. Childs Nerv. Syst. 2018, 34, 85-93. [CrossRef]

21. Moore, C.A.; Staples, J.E.; Dobyns, W.B.; Pessoa, A.; Ventura, C.V.; Fonseca, E.B.; Ribeiro, E.M.; Ventura, L.O.; Neto, N.N.; Arena, J.F.; et al. Characterizing the Pattern of Anomalies in Congenital Zika Syndrome for Pediatric Clinicians. JAMA Pediatr. 2017, 171, 288-295. [CrossRef]

22. Ribeiro, B.N.F.; Muniz, B.C.; Gasparetto, E.L.; Ventura, N.; Marchiori, E. Congenital Zika syndrome and neuroimaging findings: What do we know so far? Radiol. Bras. 2017, 50, 314-322. [CrossRef]

23. Niemeyer, B.; Hollanda, R.; Muniz, B.; Marchiori, E. What We Can Find Beyond the Classic Neuroimaging Findings of Congenital Zika Virus Syndrome? Eur. Neurol. 2020, 83, 17-24. [CrossRef] [PubMed]

24. Vouga, M.; Baud, D. Imaging of congenital Zika virus infection: The route to identification of prognostic factors. Prenat. Diagn. 2016, 36, 799-811. [CrossRef] [PubMed]

25. Wen, Z.; Song, H.; Ming, G.L. How does Zika virus cause microcephaly? Genes Dev. 2017, 31, 849-861. [CrossRef]

26. Rossi, S.L.; Ebel, G.D.; Shan, C.; Shi, P.Y.; Vasilakis, N. Did Zika Virus Mutate to Cause Severe Outbreaks? Trends Microbiol. 2018, 26, 877-885. [CrossRef]

27. Wang, J.N.; Ling, F. Zika Virus Infection and Microcephaly: Evidence for a Causal Link. Int. J. Environ. Res. Public Health 2016, 13, 1031. [CrossRef] [PubMed]

28. Alvarado, M.G.; Schwartz, D.A. Zika Virus Infection in Pregnancy, Microcephaly, and Maternal and Fetal Health: What We Think, What We Know, and What We Think We Know. Arch. Pathol. Lab. Med. 2017, 141, 26-32. [CrossRef]

29. Ellington, S.R.; Devine, O.; Bertolli, J.; Martinez Quinones, A.; Shapiro-Mendoza, C.K.; Perez-Padilla, J.; Rivera-Garcia, B.; Simeone, R.M.; Jamieson, D.J.; Valencia-Prado, M.; et al. Estimating the Number of Pregnant Women Infected with Zika Virus and Expected Infants With Microcephaly Following the Zika Virus Outbreak in Puerto Rico, 2016. JAMA Pediatr. 2016, 170, 940-945. [CrossRef]

30. Ramesh, A.; Jeffries, C.L.; Castanha, P.; Oliveira, P.A.S.; Alexander, N.; Cameron, M.; Braga, C.; Walker, T. No evidence of Zika, dengue, or chikungunya virus infection in field-caught mosquitoes from the Recife Metropolitan Region, Brazil, 2015. Wellcome Open Res. 2019, 4, 93. [CrossRef]

31. Alvarado-Socarras, J.L.; Meneses-Silvera, K.; Zarate-Vergara, A.C.; Guerrero-Gomez, C.; Rodriguez-Morales, A.J. Not everything is Zika: Congenital toxoplasmosis, still prevalent in Colombia? Rev. Peru. Med. Exp. Salud Publica 2017, 34, 332-336. [CrossRef]

32. Ticconi, C.; Pietropolli, A.; Rezza, G. Zika virus infection and pregnancy: What we do and do not know. Pathog. Glob. Health 2016, 110, 262-268. [CrossRef]

33. Garcia Serpa Osorio-de-Castro, C.; Silva Miranda, E.; Machado de Freitas, C.; Rochel de Camargo, K., Jr.; Cranmer, H.H. The Zika Virus Outbreak in Brazil: Knowledge Gaps and Challenges for Risk Reduction. Am. J. Public Health 2017, 107, 960-965. [CrossRef] [PubMed]

34. Aliota, M.T.; Bassit, L.; Bradrick, S.S.; Cox, B.; Garcia-Blanco, M.A.; Gavegnano, C.; Friedrich, T.C.; Golos, T.G.; Griffin, D.E.; Haddow, A.D.; et al. Zika in the Americas, year 2: What have we learned? What gaps remain? A report from the Global Virus Network. Antivir. Res. 2017, 144, 223-246. [CrossRef] [PubMed]

35. Pirozzi, F.; Nelson, B.; Mirzaa, G. From microcephaly to megalencephaly: Determinants of brain size. Dialogues Clin. Neurosci. 2018, 20, 267-282. [CrossRef] [PubMed]

36. Leibovitz, Z.; Lerman-Sagie, T. Diagnostic approach to fetal microcephaly. Eur. J. Paediatr. Neurol. 2018, 22, 935-943. [CrossRef] [PubMed]

37. Abuelo, D. Microcephaly syndromes. Semin. Pediatr. Neurol. 2007, 14, 118-127. [CrossRef]

38. Devakumar, D.; Bamford, A.; Ferreira, M.U.; Broad, J.; Rosch, R.E.; Groce, N.; Breuer, J.; Cardoso, M.A.; Copp, A.J.; Alexandre, P.; et al. Infectious causes of microcephaly: Epidemiology, pathogenesis, diagnosis, and management. Lancet Infect. Dis. 2018, 18, e1-e13. [CrossRef]

39. Costa, B.K.D.; Sato, D.K. Viral encephalitis: A practical review on diagnostic approach and treatment. J. Pediatr. (Rio. J.) 2020, 96 (Suppl. 1), 12-19. [CrossRef]

40. Levine, D.; Jani, J.C.; Castro-Aragon, I.; Cannie, M. How Does Imaging of Congenital Zika Compare with Imaging of Other TORCH Infections? Radiology 2017, 285, 744-761. [CrossRef]

41. Hay, J.A.; Nouvellet, P.; Donnelly, C.A.; Riley, S. Potential inconsistencies in Zika surveillance data and our understanding of risk during pregnancy. PLoS Negl. Trop. Dis. 2018, 12, e0006991. [CrossRef] 
42. Tang, B.L. Zika virus as a causative agent for primary microencephaly: The evidence so far. Arch. Microbiol. 2016, $198,595-601$. [CrossRef]

43. Bautista, L.E. Maternal Zika virus infection and newborn microcephaly-an analysis of the epidemiological evidence. Ann. Epidemiol. 2018, 28, 111-118. [CrossRef]

44. Brito, C.A.; Cordeiro, M.T. One year after the Zika virus outbreak in Brazil: From hypotheses to evidence. Rev. Soc. Bras. Med. Trop. 2016, 49, 537-543. [CrossRef]

45. Roma, J.H.F.; Alves, R.C.; Silva, V.S.D.; Ferreira, M.J.; Araujo, C.; Pavoni, J.H.C. Descriptive study of suspected congenital Zika syndrome cases during the 2015-2016 epidemic in Brazil. Rev. Soc. Bras. Med. Trop. 2019, 52, e20190105. [CrossRef] [PubMed]

46. Lobkowicz, L.; Ramond, A.; Sanchez Clemente, N.; Ximenes, R.A.A.; Miranda-Filho, D.B.; Montarroyos, U.R.; Martelli, C.M.T.; de Araujo, T.V.B.; Brickley, E.B. The frequency and clinical presentation of Zika virus coinfections: A systematic review. BMJ Glob. Health 2020, 5, e002350. [CrossRef] [PubMed]

47. Oliveira, J.F.; Rodrigues, M.S.; Skalinski, L.M.; Santos, A.E.S.; Costa, L.C.; Cardim, L.L.; Paixao, E.S.; Costa, M.; Oliveira, W.K.; Barreto, M.L.; et al. Interdependence between confirmed and discarded cases of dengue, chikungunya and Zika viruses in Brazil: A multivariate time-series analysis. PLoS ONE 2020, 15, e0228347. [CrossRef] [PubMed]

48. Silva, M.M.O.; Tauro, L.B.; Kikuti, M.; Anjos, R.O.; Santos, V.C.; Goncalves, T.S.F.; Paploski, I.A.D.; Moreira, P.S.S.; Nascimento, L.C.J.; Campos, G.S.; et al. Concomitant Transmission of Dengue, Chikungunya, and Zika Viruses in Brazil: Clinical and Epidemiological Findings from Surveillance for Acute Febrile Illness. Clin. Infect. Dis. 2019, 69, 1353-1359. [CrossRef]

49. Kumar, N.; Sharma, S.; Barua, S.; Tripathi, B.N.; Rouse, B.T. Virological and Immunological Outcomes of Coinfections. Clin. Microbiol. Rev. 2018, 31, e00111-17. [CrossRef]

50. Teixeira, M.G.; Costa Mda, C.; de Oliveira, W.K.; Nunes, M.L.; Rodrigues, L.C. The Epidemic of Zika Virus-Related Microcephaly in Brazil: Detection, Control, Etiology, and Future Scenarios. Am. J. Public Health 2016, 106, 601-605. [CrossRef]

51. Netto, E.M.; Moreira-Soto, A.; Pedroso, C.; Hoser, C.; Funk, S.; Kucharski, A.J.; Rockstroh, A.; Kummerer, B.M.; Sampaio, G.S.; Luz, E.; et al. High Zika Virus Seroprevalence in Salvador, Northeastern Brazil Limits the Potential for Further Outbreaks. mBio 2017, 8, e01390-17. [CrossRef] [PubMed]

52. Moreira-Soto, A.; Cabral, R.; Pedroso, C.; Eschbach-Bludau, M.; Rockstroh, A.; Vargas, L.A.; Postigo-Hidalgo, I.; Luz, E.; Sampaio, G.S.; Drosten, C.; et al. Exhaustive TORCH Pathogen Diagnostics Corroborate Zika Virus Etiology of Congenital Malformations in Northeastern Brazil. mSphere 2018, 3, e00278-18. [CrossRef] [PubMed]

53. Moreira-Soto, A.; Sarno, M.; Pedroso, C.; Netto, E.M.; Rockstroh, A.; Luz, E.; Feldmann, M.; Fischer, C.; Bastos, F.A.; Kummerer, B.M.; et al. Evidence for Congenital Zika Virus Infection from Neutralizing Antibody Titers in Maternal Sera, Northeastern Brazil. J. Infect. Dis. 2017, 216, 1501-1504. [CrossRef]

54. De Oliveira, W.K.; de Franca, G.V.A.; Carmo, E.H.; Duncan, B.B.; de Souza Kuchenbecker, R.; Schmidt, M.I. Infection-related microcephaly after the 2015 and 2016 Zika virus outbreaks in Brazil: A surveillance-based analysis. Lancet 2017, 390, 861-870. [CrossRef]

55. Pomar, L.; Malinger, G.; Benoist, G.; Carles, G.; Ville, Y.; Rousset, D.; Hcini, N.; Pomar, C.; Jolivet, A.; Lambert, V. Association between Zika virus and fetopathy: A prospective cohort study in French Guiana. Ultrasound Obstet. Gynecol. 2017, 49, 729-736. [CrossRef] [PubMed]

56. Oliveira, J.V.; Carvalho, T.C.X.; Giovanetti, M.; de Jesus, J.G.; Santos, C.S.; Pessoa, L.B.; Magalhaes Filho, C.F.Q.; Lima, J.G.S.; Carvalho, D.A.X.; Figueiredo, E.M.; et al. Neonatal surveillance for congenital Zika infection during the 2016 microcephaly outbreak in Salvador, Brazil: Zika virus detection in asymptomatic newborns. Int. J. Gynaecol. Obstet. 2020, 148 (Suppl. 2), 9-14. [CrossRef] [PubMed]

57. Lebov, J.F.; Arias, J.F.; Balmaseda, A.; Britt, W.; Cordero, J.F.; Galvao, L.A.; Garces, A.L.; Hambidge, K.M.; Harris, E.; Ko, A.; et al. International prospective observational cohort study of Zika in infants and pregnancy (ZIP study): Study protocol. BMC Pregnancy Childbirth 2019, 19, 282.

58. Campos, M.C.; Dombrowski, J.G.; Phelan, J.; Marinho, C.R.F.; Hibberd, M.; Clark, T.G.; Campino, S. Zika might not be acting alone: Using an ecological study approach to investigate potential co-acting risk factors for an unusual pattern of microcephaly in Brazil. PLoS ONE 2018, 13, e0201452. [CrossRef]

59. Gregory, C.J.; Oduyebo, T.; Brault, A.C.; Brooks, J.T.; Chung, K.W.; Hills, S.; Kuehnert, M.J.; Mead, P.; Meaney-Delman, D.; Rabe, I.; et al. Modes of Transmission of Zika Virus. J. Infect. Dis. 2017, 216, S875-S883. [CrossRef]

60. Magalhaes, T.; Foy, B.D.; Marques, E.T.A.; Ebel, G.D.; Weger-Lucarelli, J. Mosquito-borne and sexual transmission of Zika virus: Recent developments and future directions. Virus Res. 2018, 254, 1-9. [CrossRef]

61. Coyne, C.B.; Lazear, H.M. Zika virus-Reigniting the TORCH. Nat. Rev. Microbiol. 2016, 14, 707-715. [CrossRef] [PubMed]

62. Klase, Z.A.; Khakhina, S.; Schneider Ade, B.; Callahan, M.V.; Glasspool-Malone, J.; Malone, R. Zika Fetal Neuropathogenesis: Etiology of a Viral Syndrome. PLoS Negl. Trop. Dis. 2016, 10, e0004877. [CrossRef] [PubMed]

63. Tahotna, A.; Brucknerova, J.; Brucknerova, I. Zika virus infection from a newborn point of view. TORCH or TORZiCH? Interdiscip. Toxicol. 2018, 11, 241-246. [CrossRef] [PubMed]

64. Schwartz, D.A. The Origins and Emergence of Zika Virus, the Newest TORCH Infection: What's Old Is New Again. Arch. Pathol. Lab. Med. 2017, 141, 18-25. [CrossRef] [PubMed]

65. Morelli, F.; Souza, R.P.; Cruz, T.E.D.; Damke, G.; Damke, E.; Suehiro, T.T.; Silva, V.; Consolaro, M.E.L. Zika virus infection in the genital tract of non-pregnant females: A systematic review. Rev. Inst. Med. Trop. Sao Paulo 2020, 62, e16. [CrossRef] 
66. Da Cruz, T.E.; Souza, R.P.; Pelloso, S.M.; Morelli, F.; Suehiro, T.T.; Damke, E.; Bonfim-Mendonca, P.S.; da Silva, V.R.S.; Consolaro, M.E.L. Case Reports: Prolonged Detection of Zika Virus RNA in Vaginal and Endocervical Samples from a Brazilian Woman, 2018. Am. J. Trop. Med. Hyg. 2019, 100, 183-186. [CrossRef]

67. Murray, K.O.; Gorchakov, R.; Carlson, A.R.; Berry, R.; Lai, L.; Natrajan, M.; Garcia, M.N.; Correa, A.; Patel, S.M.; Aagaard, K.; et al. Prolonged Detection of Zika Virus in Vaginal Secretions and Whole Blood. Emerg. Infect. Dis. 2017, 23, 99-101. [CrossRef]

68. Kalkeri, R.; Murthy, K.K. Zika virus reservoirs: Implications for transmission, future outbreaks, drug and vaccine development. F1000Research 2017, 6, 1850. [CrossRef]

69. Baud, D.; Musso, D.; Vouga, M.; Alves, M.P.; Vulliemoz, N. Zika virus: A new threat to human reproduction. Am. J. Reprod. Immunol. 2017, 77, e12614. [CrossRef]

70. Kuno, G.; Mackenzie, J.S.; Junglen, S.; Hubalek, Z.; Plyusnin, A.; Gubler, D.J. Vertebrate Reservoirs of Arboviruses: Myth, Synonym of Amplifier, or Reality? Viruses 2017, 9, 185. [CrossRef]

71. Ketkar, H.; Herman, D.; Wang, P. Genetic Determinants of the Re-Emergence of Arboviral Diseases. Viruses 2019, 11, 150. [CrossRef]

72. Parrish, C.R.; Holmes, E.C.; Morens, D.M.; Park, E.C.; Burke, D.S.; Calisher, C.H.; Laughlin, C.A.; Saif, L.J.; Daszak, P. Cross-species virus transmission and the emergence of new epidemic diseases. Microbiol. Mol. Biol. Rev. 2008, 72, 457-470. [CrossRef]

73. Pierson, T.C.; Diamond, M.S. The emergence of Zika virus and its new clinical syndromes. Nature 2018, 560, 573-581. [CrossRef]

74. Woolhouse, M.E.; Gowtage-Sequeria, S. Host range and emerging and reemerging pathogens. Emerg. Infect. Dis. 2005, 11, 1842-1847. [CrossRef]

75. Woolhouse, M.E.; Haydon, D.T.; Antia, R. Emerging pathogens: The epidemiology and evolution of species jumps. Trends Ecol. Evol. 2005, 20, 238-244. [CrossRef]

76. Azeredo, E.L.; Dos Santos, F.B.; Barbosa, L.S.; Souza, T.M.A.; Badolato-Correa, J.; Sanchez-Arcila, J.C.; Nunes, P.C.G.; de-OliveiraPinto, L.M.; de Filippis, A.M.; Dal Fabbro, M.; et al. Clinical and Laboratory Profile of Zika and Dengue Infected Patients: Lessons Learned from the Co-circulation of Dengue, Zika and Chikungunya in Brazil. PLoS Curr. 2018, 10. [CrossRef] [PubMed]

77. Smith, R.V.; Milton, S.A.; Davis, P.J. Microbial models of mammalian metabolism: O-dealkylation of para-alkoxybiphenyls. Appl. Environ. Microbiol. 1982, 44, 149-152. [CrossRef] [PubMed]

78. Carlson, C.J.; Mendenhall, E. Preparing for emerging infections means expecting new syndemics. Lancet 2019, 394, 297. [CrossRef]

79. Tsuyuki, K.; Gipson, J.D.; Barbosa, R.M.; Urada, L.A.; Morisky, D.E. Preventing syndemic Zika virus, HIV/STIs and unintended pregnancy: Dual method use and consistent condom use among Brazilian women in marital and civil unions. Cult. Health Sex. 2018, 20, 1006-1022. [CrossRef]

80. Singer, M. The spread of Zika and the potential for global arbovirus syndemics. Glob. Public Health 2017, 12, 1-18. [CrossRef]

81. El-Sayed, A.; Kamel, M. Climatic changes and their role in emergence and re-emergence of diseases. Environ. Sci. Pollut. Res. Int. 2020, 27, 22336-22352. [CrossRef]

82. Sims, N.; Kasprzyk-Hordern, B. Future perspectives of wastewater-based epidemiology: Monitoring infectious disease spread and resistance to the community level. Environ. Int. 2020, 139, 105689. [CrossRef]

83. Jessel, S.; Sawyer, S.; Hernandez, D. Energy, Poverty, and Health in Climate Change: A Comprehensive Review of an Emerging Literature. Front. Public Health 2019, 7, 357. [CrossRef]

84. Ali, S.; Gugliemini, O.; Harber, S.; Harrison, A.; Houle, L.; Ivory, J.; Kersten, S.; Khan, R.; Kim, J.; LeBoa, C.; et al. Environmental and Social Change Drive the Explosive Emergence of Zika Virus in the Americas. PLoS Negl. Trop. Dis. 2017, 11, e0005135. [CrossRef]

85. Bardosh, K.L. Towards a science of global health delivery: A socio-anthropological framework to improve the effectiveness of neglected tropical disease interventions. PLoS Negl. Trop. Dis. 2018, 12, e0006537. [CrossRef]

86. Pinotti, F.; Ghanbarnejad, F.; Hovel, P.; Poletto, C. Interplay between competitive and cooperative interactions in a three-player pathogen system. R. Soc. Open Sci. 2020, 7, 190305. [CrossRef]

87. Hu, T.; Li, J.; Carr, M.J.; Duchene, S.; Shi, W. The Asian Lineage of Zika Virus: Transmission and Evolution in Asia and the Americas. Virol. Sin. 2019, 34, 1-8. [CrossRef] [PubMed]

88. Gould, E.; Pettersson, J.; Higgs, S.; Charrel, R.; de Lamballerie, X. Emerging arboviruses: Why today? One Health 2017, 4, 1-13. [CrossRef] [PubMed]

89. Liu, Z.Y.; Shi, W.F.; Qin, C.F. The evolution of Zika virus from Asia to the Americas. Nat. Rev. Microbiol. 2019, 17, 131-139. [CrossRef]

90. Walker, C.L.; Little, M.E.; Roby, J.A.; Armistead, B.; Gale, M.; Rajagopal, L., Jr.; Nelson, B.R.; Ehinger, N.; Mason, B.; Nayeri, U.; et al. Zika virus and the nonmicrocephalic fetus: Why we should still worry. Am. J. Obstet. Gynecol. 2019, 220, 45-56. [CrossRef] [PubMed]

91. Salomao, J.F.M. The congenital Zika virus infection: Still a puzzle. Childs Nerv. Syst. 2018, 34, 61-62. [CrossRef] [PubMed]

92. Lee, C.Y.; Ng, L.F.P. Zika virus: From an obscurity to a priority. Microbes Infect. 2018, 20, 635-645. [CrossRef] [PubMed]

93. Depoux, A.; Philibert, A.; Rabier, S.; Philippe, H.J.; Fontanet, A.; Flahault, A. A multi-faceted pandemic: A review of the state of knowledge on the Zika virus. Public Health Rev. 2018, 39, 10. [CrossRef]

94. Possas, C.; Brasil, P.; Marzochi, M.C.; Tanuri, A.; Martins, R.M.; Marques, E.T.; Bonaldo, M.C.; Ferreira, A.G.; Lourenco-de-Oliveira, R.; Nogueira, R.M.R.; et al. Zika puzzle in Brazil: Peculiar conditions of viral introduction and dissemination-A Review. Mem. Inst. Oswaldo Cruz 2017, 112, 319-327. [CrossRef] 
95. Brickley, E.B.; Rodrigues, L.C. Further pieces of evidence in the Zika virus and microcephaly puzzle. Lancet Child Adolesc. Health 2018, 2, 162-164. [CrossRef]

96. Musso, D.; de Pina, J.J.; Nhan, T.X.; Deparis, X. Uncommon presentation of Zika fever or co-infection? Lancet 2016, 387, 1812-1813. [CrossRef]

97. Tobar, P.; Vega, M.; Ordonez, C.; Rivera, L.; Landivar, J.; Zambrano, H. Detection of Zika Virus and Human Papilloma Virus in Cervical Cytology Samples using Two Real Time PCR Based Techniques in Ecuadorian Women diagnosed with ASCUS. P. R. Health Sci. J. 2018, 37, S96-S98.

98. Aldo, P.; You, Y.; Szigeti, K.; Horvath, T.L.; Lindenbach, B.; Mor, G. HSV-2 enhances ZIKV infection of the placenta and induces apoptosis in first-trimester trophoblast cells. Am. J. Reprod. Immunol. 2016, 76, 348-357. [CrossRef]

99. Valdespino-Vazquez, M.Y.; Sevilla-Reyes, E.E.; Lira, R.; Yocupicio-Monroy, M.; Piten-Isidro, E.; Boukadida, C.; Hernandez-Pando, R.; Soriano-Jimenez, J.D.; Herrera-Salazar, A.; Figueroa-Damian, R.; et al. Congenital Zika Syndrome and Extra-Central Nervous System Detection of Zika Virus in a Pre-term Newborn in Mexico. Clin. Infect. Dis. 2019, 68, 903-912. [CrossRef]

100. Rothan, H.A.; Bidokhti, M.R.M.; Byrareddy, S.N. Current concerns and perspectives on Zika virus co-infection with arboviruses and HIV. J. Autoimmun. 2018, 89, 11-20. [CrossRef]

101. Vouga, M.; Baud, D.; Jolivet, E.; Najioullah, F.; Monthieux, A.; Schaub, B. Congenital Zika virus syndrome...what else? Two case reports of severe combined fetal pathologies. BMC Pregnancy Childbirth 2018, 18, 356. [CrossRef]

102. Dos Santos, S.M.R.; Sanz Duro, R.L.; Santos, G.L.; Hunter, J.; da Aparecida Rodrigues Teles, M.; Brustulin, R.; de Padua Milagres, F.A.; Sabino, E.C.; Diaz, R.S.; Komninakis, S.V. Detection of coinfection with Chikungunya virus and Dengue virus serotype 2 in serum samples of patients in State of Tocantins, Brazil. J. Infect. Public Health 2020, 13, 724-729. [CrossRef]

103. Rodriguez-Morales, A.J.; Villamil-Gomez, W.E.; Franco-Paredes, C. The arboviral burden of disease caused by co-circulation and co-infection of dengue, chikungunya and Zika in the Americas. Travel. Med. Infect. Dis. 2016, 14, 177-179. [CrossRef]

104. Carrillo-Hernandez, M.Y.; Ruiz-Saenz, J.; Villamizar, L.J.; Gomez-Rangel, S.Y.; Martinez-Gutierrez, M. Co-circulation and simultaneous co-infection of dengue, chikungunya, and zika viruses in patients with febrile syndrome at the ColombianVenezuelan border. BMC Infect. Dis. 2018, 18, 61. [CrossRef]

105. Asad, H.; Carpenter, D.O. Effects of climate change on the spread of zika virus: A public health threat. Rev. Environ. Health 2018, 33, 31-42. [CrossRef]

106. Messina, J.P.; Kraemer, M.U.; Brady, O.J.; Pigott, D.M.; Shearer, F.M.; Weiss, D.J.; Golding, N.; Ruktanonchai, C.W.; Gething, P.W.; Cohn, E.; et al. Mapping global environmental suitability for Zika virus. eLife 2016, 5, e15272. [CrossRef]

107. Gyawali, N.; Bradbury, R.S.; Taylor-Robinson, A.W. The global spread of Zika virus: Is public and media concern justified in regions currently unaffected? Infect. Dis. Poverty 2016, 5, 37. [CrossRef]

108. Alaniz, A.J.; Bacigalupo, A.; Cattan, P.E. Spatial quantification of the world population potentially exposed to Zika virus. Int. J. Epidemiol. 2017, 46, 966-975. [CrossRef]

109. Wilke, A.B.B.; Caban-Martinez, A.J.; Ajelli, M.; Vasquez, C.; Petrie, W.; Beier, J.C. Mosquito Adaptation to the Extreme Habitats of Urban Construction Sites. Trends Parasitol. 2019, 35, 607-614. [CrossRef]

110. Wilke, A.B.B.; Chase, C.; Vasquez, C.; Carvajal, A.; Medina, J.; Petrie, W.D.; Beier, J.C. Urbanization creates diverse aquatic habitats for immature mosquitoes in urban areas. Sci. Rep. 2019, 9, 15335. [CrossRef]

111. Heinisch, M.R.S.; Diaz-Quijano, F.A.; Chiaravalloti-Neto, F.; Menezes Pancetti, F.G.; Rocha Coelho, R.; Dos Santos Andrade, P.; Urbinatti, P.R.; de Almeida, R.; Lima-Camara, T.N. Seasonal and spatial distribution of Aedes aegypti and Aedes albopictus in a municipal urban park in Sao Paulo, SP, Brazil. Acta Trop. 2019, 189, 104-113. [CrossRef]

112. Imperato, P.J. The Convergence of a Virus, Mosquitoes, and Human Travel in Globalizing the Zika Epidemic. J. Community Health 2016, 41, 674-679. [CrossRef]

113. Lourenco, J.; Maia de Lima, M.; Faria, N.R.; Walker, A.; Kraemer, M.U.; Villabona-Arenas, C.J.; Lambert, B.; Marques de Cerqueira, E.; Pybus, O.G.; Alcantara, L.C.; et al. Epidemiological and ecological determinants of Zika virus transmission in an urban setting. Elife 2017, 6, e29820. [CrossRef]

114. Weidner-Glunde, M.; Kruminis-Kaszkiel, E.; Savanagouder, M. Herpesviral Latency-Common Themes. Pathogens 2020, 9, 125. [CrossRef]

115. Bourgeois, C.; Gorwood, J.; Barrail-Tran, A.; Lagathu, C.; Capeau, J.; Desjardins, D.; Le Grand, R.; Damouche, A.; Bereziat, V.; Lambotte, O. Specific Biological Features of Adipose Tissue, and Their Impact on HIV Persistence. Front. Microbiol. $2019,10,2837$. [CrossRef]

116. Christensen-Quick, A.; Vanpouille, C.; Lisco, A.; Gianella, S. Cytomegalovirus and HIV Persistence: Pouring Gas on the Fire. AIDS Res. Hum. Retrovir. 2017, 33, S23-S30. [CrossRef]

117. Kumar, S.; Kumar, S.; Gupta, B. Urban health: Needs urgent attention. Indian J. Public Health 2018, 62, 214-217. [CrossRef]

118. Burke, A.; Moreau, C. Family Planning and Zika Virus: The Power of Prevention. Semin. Reprod. Med. $2016,34,305-312$.

119. Barbeito-Andres, J.; Pezzuto, P.; Higa, L.M.; Dias, A.A.; Vasconcelos, J.M.; Santos, T.M.P.; Ferreira, J.; Ferreira, R.O.; Dutra, F.F.; Rossi, A.D.; et al. Congenital Zika syndrome is associated with maternal protein malnutrition. Sci. Adv. 2020, 6, eaaw6284. [CrossRef]

120. Madewell, Z.J.; Sosa, S.; Brouwer, K.C.; Juarez, J.G.; Romero, C.; Lenhart, A.; Cordon-Rosales, C. Associations between household environmental factors and immature mosquito abundance in Quetzaltenango, Guatemala. BMC Public Health $2019,19,1729$. [CrossRef] 
121. Rodriguez, M.; Lord, A.; Sanabia, C.C.; Silverio, A.; Chuang, M.; Dolan, S.M. Understanding Zika virus as an STI: Findings from a qualitative study of pregnant women in the Bronx. Sex. Transm. Infect. 2020, 96, 80-84. [CrossRef]

122. Matysiak, A.; Roess, A. Interrelationship between Climatic, Ecologic, Social, and Cultural Determinants Affecting Dengue Emergence and Transmission in Puerto Rico and Their Implications for Zika Response. J. Trop. Med. 2017, $2017,8947067$. [CrossRef]

123. Amaral, P.; Resende de Carvalho, L.; Hernandes Rocha, T.A.; da Silva, N.C.; Vissoci, J.R.N. Geospatial modeling of microcephaly and zika virus spread patterns in Brazil. PLoS ONE 2019, 14, e0222668. [CrossRef]

124. Vissoci, J.R.N.; Rocha, T.A.H.; Silva, N.C.D.; de Sousa Queiroz, R.C.; Thomaz, E.; Amaral, P.V.M.; Lein, A.; Branco, M.; Aquino, J.J.; Rodrigues, Z.M.R.; et al. Zika virus infection and microcephaly: Evidence regarding geospatial associations. PLoS Negl. Trop. Dis. 2018, 12, e0006392. [CrossRef]

125. Meneses, J.D.A.; Ishigami, A.C.; de Mello, L.M.; de Albuquerque, L.L.; de Brito, C.A.A.; Cordeiro, M.T.; Pena, L.J. Lessons Learned at the Epicenter of Brazil's Congenital Zika Epidemic: Evidence From 87 Confirmed Cases. Clin. Infect. Dis. 2017, 64, 1302-1308. [CrossRef]

126. Angueyra, C.; Abou Hatab, H.; Pathak, A. Congenital Cytomegalovirus and Zika Infections. Indian J. Pediatr. 2020, 87, 840-845. [CrossRef]

127. Joao, E.C.; Gouvea, M.I.; Teixeira, M.L.; Mendes-Silva, W.; Esteves, J.S.; Santos, E.M.; Ledesma, L.A.; Gomes, A.P.; Cruz, M.L. Zika Virus Infection Associated With Congenital Birth Defects in a HIV-infected Pregnant Woman. Pediatr. Infect. Dis. J. 2017, 36, 500-501. [CrossRef]

128. Pereira, L. Congenital Viral Infection: Traversing the Uterine-Placental Interface. Annu. Rev. Virol. 2018, 5, 273-299. [CrossRef]

129. Weldon, C.T.; Riley-Powell, A.R.; Aguerre, I.M.; Celis Nacimento, R.A.; Morrison, A.C.; Oberhelman, R.A.; Paz-Soldan, V.A. "Zika is everywhere": A qualitative exploration of knowledge, attitudes and practices towards Zika virus among women of reproductive age in Iquitos, Peru. PLoS Negl. Trop. Dis. 2018, 12, e0006708. [CrossRef] [PubMed]

130. Grazel, R.; Harris-Haman, P. Zika Virus Infection: A Vector-Borne Threat to Pregnant Women and Infants. Adv. Neonatal Care 2018, 18, 350-359. [CrossRef]

131. Boldogh, I.; Albrecht, T.; Porter, D.D. Persistent viral infections. In Medical Microbiology, 4th ed.; Baron, S., Ed.; University of Texas Medical Branch at Galveston: Galveston, TX, USA, 1996.

132. Kane, M.; Golovkina, T. Common threads in persistent viral infections. J. Virol. 2010, 84, 4116-4123. [CrossRef]

133. Mathew, J., Jr.; Sapra, A. Herpes simplex type 2. In StatPearls; StatPearls Publishing LLC.: Treasure Island, FL, USA, 2020.

134. Looker, K.J.; Magaret, A.S.; May, M.T.; Turner, K.M.; Vickerman, P.; Gottlieb, S.L.; Newman, L.M. Global and Regional Estimates of Prevalent and Incident Herpes Simplex Virus Type 1 Infections in 2012. PLoS ONE 2015, 10, e0140765. [CrossRef]

135. Looker, K.J.; Magaret, A.S.; Turner, K.M.; Vickerman, P.; Gottlieb, S.L.; Newman, L.M. Global estimates of prevalent and incident herpes simplex virus type 2 infections in 2012. PLoS ONE 2015, 10, e114989. [CrossRef]

136. Sacks, S.L.; Griffiths, P.D.; Corey, L.; Cohen, C.; Cunningham, A.; Dusheiko, G.M.; Self, S.; Spruance, S.; Stanberry, L.R.; Wald, A.; et al. HSV-2 transmission. Antivir. Res. 2004, 63 (Suppl. 1), S27-S35. [CrossRef]

137. Sacks, S.L.; Griffiths, P.D.; Corey, L.; Cohen, C.; Cunningham, A.; Dusheiko, G.M.; Self, S.; Spruance, S.; Stanberry, L.R.; Wald, A.; et al. HSV shedding. Antivir. Res. 2004, 63 (Suppl. 1), S19-S26. [CrossRef]

138. Sacks, S.L.; Griffiths, P.D.; Corey, L.; Cohen, C.; Cunningham, A.; Dusheiko, G.M.; Self, S.; Spruance, S.; Stanberry, L.R.; Wald, A.; et al. Introduction: Is viral shedding a surrogate marker for transmission of genital herpes? Antivir. Res. 2004, 63 (Suppl. 1), S3-S9. [CrossRef]

139. Wald, A. Herpes simplex virus type 2 transmission: Risk factors and virus shedding. Herpes 2004, 11 (Suppl. 3), 130A-137A.

140. Wald, A.; Matson, P.; Ryncarz, A.; Corey, L. Detection of herpes simplex virus DNA in semen of men with genital HSV-2 infection. Sex. Transm. Dis. 1999, 26, 1-3. [CrossRef]

141. Pieknik, J.R.; Bertke, A.S.; Krause, P.R. Herpes Simplex Virus 2 in Autonomic Ganglia: Evidence for Spontaneous Reactivation. J. Virol. 2019, 93, e00227-19. [CrossRef] [PubMed]

142. Lieberman, P.M. Chromatin regulation of virus infection. Trends Microbiol. 2006, 14, 132-140. [CrossRef]

143. Lieberman, P.M. Epigenetics and Genetics of Viral Latency. Cell Host Microbe 2016, 19, 619-628. [CrossRef] [PubMed]

144. Wald, A.; Zeh, J.; Selke, S.; Warren, T.; Ryncarz, A.J.; Ashley, R.; Krieger, J.N.; Corey, L. Reactivation of genital herpes simplex virus type 2 infection in asymptomatic seropositive persons. N. Engl. J. Med. 2000, 342, 844-850. [CrossRef]

145. Anzivino, E.; Fioriti, D.; Mischitelli, M.; Bellizzi, A.; Barucca, V.; Chiarini, F.; Pietropaolo, V. Herpes simplex virus infection in pregnancy and in neonate: Status of art of epidemiology, diagnosis, therapy and prevention. Virol. J. 2009, 6, 40. [CrossRef] [PubMed]

146. Groves, M.J. Genital Herpes: A Review. Am. Fam. Physician. 2016, 93, 928-934.

147. Cross, S.N.; Potter, J.A.; Aldo, P.; Kwon, J.Y.; Pitruzzello, M.; Tong, M.; Guller, S.; Rothlin, C.V.; Mor, G.; Abrahams, V.M. Viral Infection Sensitizes Human Fetal Membranes to Bacterial Lipopolysaccharide by MERTK Inhibition and Inflammasome Activation. J. Immunol. 2017, 199, 2885-2895. [CrossRef]

148. Guidry, J.T.; Scott, R.S. The interaction between human papillomavirus and other viruses. Virus Res. 2017, 231, 139-147. [CrossRef]

149. Lima, L.R.P.; Fernandes, L.; Villela, D.A.M.; Morgado, M.G.; Pilotto, J.H.; de Paula, V.S. Co-infection of human herpesvirus type 2 (HHV-2) and human immunodeficiency virus (HIV) among pregnant women in Rio de Janeiro, Brazil. AIDS Care 2018, 30, 378-382. [CrossRef] [PubMed] 
150. Wald, A.; Schacker, T.; Corey, L. HSV-2 and HIV: Consequences of an endemic opportunistic infection. Step Perspect. 1997, 9, $2-4$. [PubMed]

151. Lima, L.R.P.; Araujo, N.A.; Guterres, A.; Pilotto, J.H.; Niel, C.; Paula, V.S. Novel variants of human herpesvirus 2 from Brazilian HIV-1 coinfected subjects. Mem. Inst. Oswaldo Cruz 2018, 113, e180328. [CrossRef]

152. Amerson-Brown, M.H.; Miller, A.L.; Maxwell, C.A.; White, M.M.; Vincent, K.L.; Bourne, N.; Pyles, R.B. Cultivated Human Vaginal Microbiome Communities Impact Zika and Herpes Simplex Virus Replication in ex vivo Vaginal Mucosal Cultures. Front. Microbiol. 2018, 9, 3340. [CrossRef] [PubMed]

153. Miranda, C.A.; Lima, E.G.; de Lima, D.B.; Cobucci, R.N.; Cornetta Mda, C.; Fernandes, T.A.; de Azevedo, P.R.; de Azevedo, J.C.; de Araujo, J.M.; Fernandes, J.V. Genital infection with herpes simplex virus types 1 and 2 in women from natal, Brazil. ISRN Obstet. Gynecol. 2014, 2014, 323657. [CrossRef]

154. Araujo, L.M.; Ferreira, M.L.; Nascimento, O.J. Guillain-Barre syndrome associated with the Zika virus outbreak in Brazil. Arq. Neuropsiquiatr. 2016, 74, 253-255. [CrossRef]

155. Brown, E.L.; Gardella, C.; Malm, G.; Prober, C.G.; Forsgren, M.; Krantz, E.M.; Arvin, A.M.; Yasukawa, L.L.; Mohan, K.; Brown, Z.; et al. Effect of maternal herpes simplex virus (HSV) serostatus and HSV type on risk of neonatal herpes. Acta Obstet. Gynecol. Scand. 2007, 86, 523-529. [CrossRef]

156. Johnston, C.; Koelle, D.M.; Wald, A. HSV-2: In pursuit of a vaccine. J. Clin. Investig. 2011, 121, 4600-4609. [CrossRef] [PubMed]

157. Ades, A.E.; Thorne, C.; Soriano-Arandes, A.; Peckham, C.S.; Brown, D.W.; Lang, D.; Morris, J.G.; Christie, C.D.C.; Giaquinto, C. Researching Zika in pregnancy: Lessons for global preparedness. Lancet Infect. Dis. 2020, 20, e61-e68. [CrossRef]

158. Cairns, T.M.; Ditto, N.T.; Lou, H.; Brooks, B.D.; Atanasiu, D.; Eisenberg, R.J.; Cohen, G.H. Global sensing of the antigenic structure of herpes simplex virus gD using high-throughput array-based SPR imaging. PLoS Pathog. 2017, 13, e1006430. [CrossRef]

159. Jones, S.T.; Cagno, V.; Janecek, M.; Ortiz, D.; Gasilova, N.; Piret, J.; Gasbarri, M.; Constant, D.A.; Han, Y.; Vukovic, L.; et al. Modified cyclodextrins as broad-spectrum antivirals. Sci. Adv. 2020, 6, eaax9318. [CrossRef] [PubMed]

160. Flamand, L.; Komaroff, A.L.; Arbuckle, J.H.; Medveczky, P.G.; Ablashi, D.V. Review, part 1: Human herpesvirus-6-basic biology, diagnostic testing, and antiviral efficacy. J. Med. Virol. 2010, 82, 1560-1568. [CrossRef]

161. Revest, M.; Minjolle, S.; Veyer, D.; Lagathu, G.; Michelet, C.; Colimon, R. Detection of HHV-6 in over a thousand samples: New types of infection revealed by an analysis of positive results. J. Clin. Virol. 2011, 51, 20-24. [CrossRef] [PubMed]

162. Ablashi, D.; Agut, H.; Alvarez-Lafuente, R.; Clark, D.A.; Dewhurst, S.; DiLuca, D.; Flamand, L.; Frenkel, N.; Gallo, R.; Gompels, U.A.; et al. Classification of HHV-6A and HHV-6B as distinct viruses. Arch. Virol. 2014, 159, 863-870. [CrossRef] [PubMed]

163. Kawamura, Y.; Sugata, K.; Ihira, M.; Mihara, T.; Mutoh, T.; Asano, Y.; Yoshikawa, T. Different characteristics of human herpesvirus 6 encephalitis between primary infection and viral reactivation. J. Clin. Virol. 2011, 51, 12-19. [CrossRef] [PubMed]

164. Bortolotti, D.; Gentili, V.; Rotola, A.; Cultrera, R.; Marci, R.; Di Luca, D.; Rizzo, R. HHV-6A infection of endometrial epithelial cells affects immune profile and trophoblast invasion. Am. J. Reprod. Immunol. 2019, 82, e13174. [CrossRef] [PubMed]

165. Bortolotti, D.; Soffritti, I.; D’Accolti, M.; Gentili, V.; Di Luca, D.; Rizzo, R.; Caselli, E. HHV-6A Infection of Endometrial Epithelial Cells Affects miRNA Expression and Trophoblast Cell Attachment. Reprod. Sci. 2020, 27, 779-786. [CrossRef] [PubMed]

166. Yilmaz, M.; Yasar, C.; Aydin, S.; Derin, O.; Polat, B.; Ertan, G.; Ceylan, B.; Mert, A. Human Herpesvirus 6 encephalitis in an immunocompetent pregnant patient and review of the literature. Clin. Neurol. Neurosurg. 2018, 171, 106-108. [CrossRef] [PubMed]

167. Pantry, S.N.; Medveczky, P.G. Latency, Integration, and Reactivation of Human Herpesvirus-6. Viruses 2017, 9, 194. [CrossRef]

168. Cruz-Munoz, M.E.; Fuentes-Panana, E.M. Beta and Gamma Human Herpesviruses: Agonistic and Antagonistic Interactions with the Host Immune System. Front. Microbiol. 2017, 8, 2521. [CrossRef] [PubMed]

169. Collin, V.; Flamand, L. HHV-6A/B Integration and the Pathogenesis Associated with the Reactivation of Chromosomally Integrated HHV-6A/B. Viruses 2017, 9, 160. [CrossRef] [PubMed]

170. Osterrieder, N.; Wallaschek, N.; Kaufer, B.B. Herpesvirus Genome Integration into Telomeric Repeats of Host Cell Chromosomes. Annu. Rev. Virol. 2014, 1, 215-235. [CrossRef]

171. Arbuckle, J.H.; Medveczky, M.M.; Luka, J.; Hadley, S.H.; Luegmayr, A.; Ablashi, D.; Lund, T.C.; Tolar, J.; De Meirleir, K.; Montoya, J.G.; et al. The latent human herpesvirus-6A genome specifically integrates in telomeres of human chromosomes in vivo and in vitro. Proc. Natl. Acad. Sci. USA 2010, 107, 5563-5568. [CrossRef]

172. Tanaka-Taya, K.; Sashihara, J.; Kurahashi, H.; Amo, K.; Miyagawa, H.; Kondo, K.; Okada, S.; Yamanishi, K. Human herpesvirus 6 (HHV-6) is transmitted from parent to child in an integrated form and characterization of cases with chromosomally integrated HHV-6 DNA. J. Med. Virol 2004, 73, 465-473. [CrossRef]

173. Flamand, L. Chromosomal Integration by Human Herpesviruses 6A and 6B. Adv. Exp. Med. Biol. 2018, 1045, $209-226$.

174. Peddu, V.; Dubuc, I.; Gravel, A.; Xie, H.; Huang, M.L.; Tenenbaum, D.; Jerome, K.R.; Tardif, J.C.; Dube, M.P.; Flamand, L.; et al. Inherited Chromosomally Integrated Human Herpesvirus 6 Demonstrates Tissue-Specific RNA Expression In Vivo That Correlates with an Increased Antibody Immune Response. J. Virol. 2019, 94, e01418-19. [CrossRef]

175. Handous, I.; Achour, B.; Marzouk, M.; Rouis, S.; Hazgui, O.; Brini, I.; Khelif, A.; Hannachi, N.; Boukadida, J. Co-infections of human herpesviruses (CMV, HHV-6, HHV-7 and EBV) in non-transplant acute leukemia patients undergoing chemotherapy. Virol. J. 2020, 17, 37. [CrossRef]

176. Kumata, R.; Ito, J.; Sato, K. Inherited chromosomally integrated HHV-6 possibly modulates human gene expression. Virus Genes 2020, 56, 386-389. [CrossRef] 
177. Gravel, A.; Dubuc, I.; Morissette, G.; Sedlak, R.H.; Jerome, K.R.; Flamand, L. Inherited chromosomally integrated human herpesvirus 6 as a predisposing risk factor for the development of angina pectoris. Proc. Natl. Acad. Sci. USA 2015, 112, 8058-8063. [CrossRef] [PubMed]

178. Pellett, P.E.; Ablashi, D.V.; Ambros, P.F.; Agut, H.; Caserta, M.T.; Descamps, V.; Flamand, L.; Gautheret-Dejean, A.; Hall, C.B.; Kamble, R.T.; et al. Chromosomally integrated human herpesvirus 6: Questions and answers. Rev. Med. Virol. 2012, 22, $144-155$. [CrossRef] [PubMed]

179. Drago, F.; Broccolo, F.; Javor, S.; Drago, F.; Rebora, A.; Parodi, A. Evidence of human herpesvirus-6 and -7 reactivation in miscarrying women with pityriasis rosea. J. Am. Acad. Dermatol. 2014, 71, 198-199. [CrossRef] [PubMed]

180. Drago, F.; Ciccarese, G.; Herzum, A.; Rebora, A.; Parodi, A. Pityriasis Rosea during Pregnancy: Major and Minor Alarming Signs. Dermatology 2018, 234, 31-36. [CrossRef] [PubMed]

181. Ohashi, M.; Yoshikawa, T.; Ihira, M.; Suzuki, K.; Suga, S.; Tada, S.; Udagawa, Y.; Sakui, H.; Iida, K.; Saito, Y.; et al. Reactivation of human herpesvirus 6 and 7 in pregnant women. J. Med. Virol. 2002, 67, 354-358. [CrossRef]

182. Dahl, H.; Fjaertoft, G.; Norsted, T.; Wang, F.Z.; Mousavi-Jazi, M.; Linde, A. Reactivation of human herpesvirus 6 during pregnancy. J. Infect. Dis. 1999, 180, 2035-2038. [CrossRef]

183. Caserta, M.T.; Hall, C.B.; Schnabel, K.; Lofthus, G.; McDermott, M.P. Human herpesvirus (HHV)-6 and HHV-7 infections in pregnant women. J. Infect. Dis. 2007, 196, 1296-1303.

184. Marci, R.; Gentili, V.; Bortolotti, D.; Lo Monte, G.; Caselli, E.; Bolzani, S.; Rotola, A.; Di Luca, D.; Rizzo, R. Presence of HHV-6A in Endometrial Epithelial Cells from Women with Primary Unexplained Infertility. PLoS ONE 2016, 11, e0158304. [CrossRef] [PubMed]

185. Coulam, C.B.; Bilal, M.; Salazar Garcia, M.D.; Katukurundage, D.; Elazzamy, H.; Fernandez, E.F.; Kwak-Kim, J.; Beaman, K.; Dambaeva, S.V. Prevalence of HHV-6 in endometrium from women with recurrent implantation failure. Am. J. Reprod. Immunol. 2018, 80, e12862. [CrossRef] [PubMed]

186. Caselli, E.; Bortolotti, D.; Marci, R.; Rotola, A.; Gentili, V.; Soffritti, I.; D’Accolti, M.; Lo Monte, G.; Sicolo, M.; Barao, I.; et al. HHV-6A Infection of Endometrial Epithelial Cells Induces Increased Endometrial NK Cell-Mediated Cytotoxicity. Front. Microbiol. 2017, 8, 2525. [CrossRef] [PubMed]

187. Hall, C.B.; Long, C.E.; Schnabel, K.C.; Caserta, M.T.; McIntyre, K.M.; Costanzo, M.A.; Knott, A.; Dewhurst, S.; Insel, R.A.; Epstein, L.G. Human herpesvirus-6 infection in children. A prospective study of complications and reactivation. N. Engl. J. Med. 1994, 331, 432-438. [CrossRef] [PubMed]

188. Hall, C.B.; Caserta, M.T.; Schnabel, K.C.; Shelley, L.M.; Carnahan, J.A.; Marino, A.S.; Yoo, C.; Lofthus, G.K. Transplacental congenital human herpesvirus 6 infection caused by maternal chromosomally integrated virus. J. Infect. Dis. 2010, 201, 505-507. [CrossRef] [PubMed]

189. Adams, O.; Krempe, C.; Kogler, G.; Wernet, P.; Scheid, A. Congenital infections with human herpesvirus 6. J. Infect. Dis. 1998, 178, 544-546. [CrossRef]

190. Goldberg, S.H.; Albright, A.V.; Lisak, R.P.; Gonzalez-Scarano, F. Polymerase chain reaction analysis of human herpesvirus-6 sequences in the sera and cerebrospinal fluid of patients with multiple sclerosis. J. Neurovirol. 1999, 5, 134-139. [CrossRef]

191. Dowd, K.A.; Ko, S.Y.; Morabito, K.M.; Yang, E.S.; Pelc, R.S.; DeMaso, C.R.; Castilho, L.R.; Abbink, P.; Boyd, M.; Nityanandam, R.; et al. Rapid development of a DNA vaccine for Zika virus. Science 2016, 354, 237-240. [CrossRef]

192. De Los Angeles Ribas, M.; Tejero, Y.; Cordero, Y.; Perez, D.; Sausy, A.; Muller, C.P.; Hubschen, J.M. Identification of human parvovirus B19 among measles and rubella suspected patients from Cuba. J. Med. Virol. 2019, 91, 1351-1354. [CrossRef]

193. Cohen, J.I. Epstein-Barr virus infection. N. Engl. J. Med. 2000, 343, 481-492. [CrossRef] [PubMed]

194. Chen, T.; Hudnall, S.D. Anatomical mapping of human herpesvirus reservoirs of infection. Mod. Pathol. 2006, 19, 726-737. [CrossRef] [PubMed]

195. De Paoli, P.; Carbone, A. Microenvironmental abnormalities induced by viral cooperation: Impact on lymphomagenesis. Semin. Cancer Biol. 2015, 34, 70-80. [CrossRef] [PubMed]

196. Gulley, M.L. Molecular diagnosis of Epstein-Barr virus-related diseases. J. Mol. Diagn. 2001, 3, 1-10. [CrossRef]

197. Kenney, S.C.; Mertz, J.E. Regulation of the latent-lytic switch in Epstein-Barr virus. Semin. Cancer Biol. 2014, 26, 60-68. [CrossRef]

198. Purtilo, D.T.; Sakamoto, K. Reactivation of Epstein-Barr virus in pregnant women: Social factors, and immune competence as determinants of lymphoproliferative diseases-a hypothesis. Med. Hypotheses 1982, 8, 401-408. [CrossRef]

199. Haeri, S.; Baker, A.M.; Boggess, K.A. Prevalence of Epstein-Barr virus reactivation in pregnancy. Am. J. Perinatol. 2010, $27,715-719$. [CrossRef]

200. Kim, Y.; Kim, H.S.; Park, J.S.; Kim, C.J.; Kim, W.H. Identification of Epstein-Barr Virus in the Human Placenta and Its Pathologic Characteristics. J. Korean Med. Sci. 2017, 32, 1959-1966. [CrossRef]

201. Avgil, M.; Diav-Citrin, O.; Shechtman, S.; Arnon, J.; Wajnberg, R.; Ornoy, A. Epstein-Barr virus infection in pregnancy-A prospective controlled study. Reprod. Toxicol. 2008, 25, 468-471. [CrossRef]

202. Avgil, M.; Ornoy, A. Herpes simplex virus and Epstein-Barr virus infections in pregnancy: Consequences of neonatal or intrauterine infection. Reprod. Toxicol. 2006, 21, 436-445. [CrossRef]

203. Toth, F.D.; Aboagye-Mathiesen, G.; Nemes, J.; Liu, X.; Andirko, I.; Hager, H.; Zdravkovic, M.; Szabo, J.; Kiss, J.; Aranyosi, J.; et al. Epstein-Barr virus permissively infects human syncytiotrophoblasts in vitro and induces replication of human $\mathrm{T}$ cell leukemia-lymphoma virus type I in dually infected cells. Virology 1997, 229, 400-414. [CrossRef] 
204. Ouedraogo, A.R.; Kabre, M.; Bisseye, C.; Zohoncon, T.M.; Asshi, M.; Soubeiga, S.T.; Diarra, B.; Traore, L.; Djigma, F.W.; Ouermi, D.; et al. Molecular tests in diagnosis of Cytomegalovirus (CMV), human herpesvirus 6 (HHV-6) and Epstein-Barr virus (EBV) using real-time PCR in HIV positive and HIV-negative pregnant women in Ouagadougou, Burkina Faso. Pan Afr. Med. J. 2016, 24, 223.

205. Van der Beken, Y.; De Geyter, D.; Van Esbroeck, M. Performance evaluation of the Diasorin LIAISON(R) XL Zika capture IgM CLIA test. Diagn. Microbiol. Infect. Dis. 2019, 95, 144-148. [CrossRef]

206. Tiwari, V.; Bergman, M.J. Viral Arthritis. In StatPearls; StatPearls Publishing: Treasure Island, FL, USA, 2020.

207. Knopfel, N.; Noguera-Morel, L.; Latour, I.; Torrelo, A. Viral exanthems in children: A great imitator. Clin. Dermatol. 2019, 37, 213-226. [CrossRef] [PubMed]

208. Avanzi, S.; Leoni, V.; Rotola, A.; Alviano, F.; Solimando, L.; Lanzoni, G.; Bonsi, L.; Di Luca, D.; Marchionni, C.; Alvisi, G.; et al. Susceptibility of human placenta derived mesenchymal stromal/stem cells to human herpesviruses infection. PLoS ONE 2013, 8, e71412. [CrossRef] [PubMed]

209. Fritsch, M.; Jaffe, E.S.; Griffin, C.; Camacho, J.; Raffeld, M.; Kingma, D.W. Lymphoproliferative disorder of fetal origin presenting as oligohydramnios. Am. J. Surg. Pathol. 1999, 23, 595-601. [CrossRef] [PubMed]

210. Gomes, H.; Huyett, P.; Laver, N.; Wein, R.O. A unique presentation of Epstein-Barr virus-associated Castleman's disease. Am. J. Otolaryngol. 2013, 34, 262-264. [CrossRef] [PubMed]

211. Hernandez, J.L.; Gomez-Roman, J.; Ramos-Estebanez, C.; Nan, D.; Martin-Oviedo, J.; Riancho, J.A.; Gonzalez-Macias, J. Human herpesvirus 8 and Epstein-Barr virus coinfection in localized Castleman disease during pregnancy. Haematologica 2005, 90 , ECR35. [PubMed]

212. Devergne, O.; Birkenbach, M.; Kieff, E. Epstein-Barr virus-induced gene 3 and the p35 subunit of interleukin 12 form a novel heterodimeric hematopoietin. Proc. Natl. Acad. Sci. USA 1997, 94, 12041-12046. [CrossRef] [PubMed]

213. Devergne, O.; Cahir McFarland, E.D.; Mosialos, G.; Izumi, K.M.; Ware, C.F.; Kieff, E. Role of the TRAF binding site and NF-kappaB activation in Epstein-Barr virus latent membrane protein 1-induced cell gene expression. J. Virol. 1998, 72, 7900-7908. [CrossRef]

214. Devergne, O.; Hummel, M.; Koeppen, H.; Le Beau, M.M.; Nathanson, E.C.; Kieff, E.; Birkenbach, M. A novel interleukin-12 p40-related protein induced by latent Epstein-Barr virus infection in B lymphocytes. J. Virol. 1996, 70, 1143-1153. [CrossRef] [PubMed]

215. Devergne, O.; Peuchmaur, M.; Humbert, M.; Navratil, E.; Leger-Ravet, M.B.; Crevon, M.C.; Petit, M.A.; Galanaud, P.; Emilie, D. In vivo expression of IL-1 beta and IL-6 genes during viral infections in human. Eur. Cytokine Netw. 1991, 2, 183-194. [PubMed]

216. Rosenberg, A.Z.; Yu, W.; Hill, D.A.; Reyes, C.A.; Schwartz, D.A. Placental Pathology of Zika Virus: Viral Infection of the Placenta Induces Villous Stromal Macrophage (Hofbauer Cell) Proliferation and Hyperplasia. Arch. Pathol. Lab. Med. 2017, 141, 43-48. [CrossRef] [PubMed]

217. Schwartz, D.A. Viral infection, proliferation, and hyperplasia of Hofbauer cells and absence of inflammation characterize the placental pathology of fetuses with congenital Zika virus infection. Arch. Gynecol. Obstet. 2017, 295, 1361-1368. [CrossRef]

218. Ganaie, S.S.; Qiu, J. Recent Advances in Replication and Infection of Human Parvovirus B19. Front. Cell Infect. Microbiol. 2018, 8, 166. [CrossRef]

219. Qiu, J.; Söderlund-Venermo, M.; Young, N.S. Human Parvoviruses. Clin. Microbiol. Rev. 2017, 30, 43-113. [CrossRef]

220. Das, P.; Chatterjee, K.; Chattopadhyay, N.R.; Choudhuri, T. Evolutionary aspects of Parvovirus B-19V associated diseases and their pathogenesis patterns with an emphasis on vaccine development. Virusdisease 2019, 30, 32-42. [CrossRef]

221. Rogo, L.D.; Mokhtari-Azad, T.; Kabir, M.H.; Rezaei, F. Human parvovirus B19: A review. Acta Virol. 2014, 58, 199-213. [CrossRef]

222. Skuja, S.; Vilmane, A.; Svirskis, S.; Groma, V.; Murovska, M. Evidence of Human Parvovirus B19 Infection in the Post-Mortem Brain Tissue of the Elderly. Viruses 2018, 10, 582. [CrossRef]

223. Janovitz, T.; Wong, S.; Young, N.S.; Oliveira, T.; Falck-Pedersen, E. Parvovirus B19 integration into human CD36+ erythroid progenitor cells. Virology 2017, 511, 40-48. [CrossRef]

224. Zou, W.; Wang, Z.; Xiong, M.; Chen, A.Y.; Xu, P.; Ganaie, S.S.; Badawi, Y.; Kleiboeker, S.; Nishimune, H.; Ye, S.Q.; et al. Human Parvovirus B19 Utilizes Cellular DNA Replication Machinery for Viral DNA Replication. J. Virol. 2018, 92, e01881-17. [CrossRef]

225. Chen, A.Y.; Kleiboeker, S.; Qiu, J. Productive parvovirus B19 infection of primary human erythroid progenitor cells at hypoxia is regulated by STAT5A and MEK signaling but not HIFalpha. PLoS Pathog. 2011, 7, e1002088. [CrossRef]

226. Devhare, P.; Meyer, K.; Steele, R.; Ray, R.B.; Ray, R. Zika virus infection dysregulates human neural stem cell growth and inhibits differentiation into neuroprogenitor cells. Cell Death Dis. 2017, 8, e3106. [CrossRef] [PubMed]

227. Lamont, R.F.; Sobel, J.D.; Vaisbuch, E.; Kusanovic, J.P.; Mazaki-Tovi, S.; Kim, S.K.; Uldbjerg, N.; Romero, R. Parvovirus B19 infection in human pregnancy. BJOG Int. J. Obstet. Gynaecol. 2011, 118, 175-186. [CrossRef]

228. Jordan, J.A.; Huff, D.; DeLoia, J.A. Placental cellular immune response in women infected with human parvovirus B19 during pregnancy. Clin. Diagn. Lab. Immunol. 2001, 8, 288-292. [CrossRef] [PubMed]

229. Wegner, C.C.; Jordan, J.A. Human parvovirus B19 VP2 empty capsids bind to human villous trophoblast cells in vitro via the globoside receptor. Infect. Dis. Obstet. Gynecol. 2004, 12, 69-78. [CrossRef] [PubMed]

230. Jordan, J.A. Diagnosing human parvovirus B19 infection: Guidelines for test selection. Mol. Diagn. 2001, 6, 307-312. [CrossRef] [PubMed]

231. Jordan, J.A.; Butchko, A.R. Apoptotic activity in villous trophoblast cells during B19 infection correlates with clinical outcome: Assessment by the caspase-related M30 Cytodeath antibody. Placenta 2002, 23, 547-553. [CrossRef] 
232. Bonvicini, F.; Bua, G.; Gallinella, G. Parvovirus B19 infection in pregnancy-awareness and opportunities. Curr. Opin. Virol. 2017, 27, 8-14. [CrossRef]

233. Weigel-Kelley, K.A.; Yoder, M.C.; Chen, L.; Srivastava, A. Role of integrin cross-regulation in parvovirus B19 targeting. Hum. Gene Ther. 2006, 17, 909-920. [CrossRef]

234. Weigel-Kelley, K.A.; Yoder, M.C.; Srivastava, A. Alpha5beta1 integrin as a cellular coreceptor for human parvovirus B19: Requirement of functional activation of beta1 integrin for viral entry. Blood 2003, 102, 3927-3933. [CrossRef]

235. Jordan, J.A.; DeLoia, J.A. Globoside expression within the human placenta. Placenta 1999, 20, 103-108. [CrossRef]

236. Tzang, B.S.; Chiang, S.Y.; Chan, H.C.; Liu, C.H.; Hsu, T.C. Human parvovirus B19 antibodies induce altered membrane protein expression and apoptosis of BeWo trophoblasts. Mol. Med. Rep. 2016, 14, 4399-4406. [CrossRef]

237. Weigel-Kelley, K.A.; Yoder, M.C.; Srivastava, A. Recombinant human parvovirus B19 vectors: Erythrocyte P antigen is necessary but not sufficient for successful transduction of human hematopoietic cells. J. Virol. 2001, 75, 4110-4116. [CrossRef]

238. Bieri, J.; Ros, C. Globoside Is Dispensable for Parvovirus B19 Entry but Essential at a Postentry Step for Productive Infection. J. Virol. 2019, 93, e0972-19. [CrossRef] [PubMed]

239. Barlinn, R.; Trogstad, L.; Rollag, H.; Froen, F.; Magnus, P.; Dudman, S.G. Parvovirus B19 DNAemia in pregnant women in relation to perinatal death: A nested case-control study within a large population-based pregnancy cohort. Acta Obstet. Gynecol. Scand. 2020, 99, 856-864. [CrossRef]

240. Morelli, P.; Bestetti, G.; Longhi, E.; Parravicini, C.; Corbellino, M.; Meroni, L. Persistent parvovirus B19-induced anemia in an HIV-infected patient under HAART. Case report and review of literature. Eur. J. Clin. Microbiol. Infect. Dis. 2007, 26, 833-837. [CrossRef]

241. Tavil, B.; Sanal, O.; Turul, T.; Yel, L.; Gurgey, A.; Gumruk, F. Parvovirus B19-induced persistent pure red cell aplasia in a child with T-cell immunodeficiency. Pediatr. Hematol. Oncol. 2009, 26, 63-68. [CrossRef] [PubMed]

242. Sterpu, R.; Ichou, H.; Mahe, I.; Mortier, E. Reactivation of parvovirus B19 infection in an HIV-infected woman. Rev. Med. Interne 2014, 35, 396-398. [CrossRef] [PubMed]

243. De Moraes, J.C.; Toscano, C.M.; de Barros, E.N.; Kemp, B.; Lievano, F.; Jacobson, S.; Afonso, A.M.; Strebel, P.M.; Cairns, K.L.; VigiFex, G. Etiologies of rash and fever illnesses in Campinas, Brazil. J. Infect. Dis. 2011, 204 (Suppl. 2), S627-S636. [CrossRef]

244. Ciccone, F.H.; Carvalhanas, T.R.; Afonso, A.M.; Flannery, B.; Waldman, E.A. Investigation of measles IgM-seropositive cases of febrile rash illnesses in the absence of documented measles virus transmission, State of Sao Paulo, Brazil, 2000-2004. Rev. Soc. Bras. Med. Trop. 2010, 43, 234-239. [CrossRef] [PubMed]

245. Fahsbender, E.; Charlys da-Costa, A.; Elise Gill, D.; Augusto de Padua Milagres, F.; Brustulin, R.; Julio Costa Monteiro, F.; Octavio da Silva Rego, M.; Soares D'Athaide Ribeiro, E.; Cerdeira Sabino, E.; Delwart, E. Plasma virome of 781 Brazilians with unexplained symptoms of arbovirus infection include a novel parvovirus and densovirus. PLoS ONE 2020, 15, e0229993. [CrossRef]

246. Izumida, T.; Sakata, H.; Nakamura, M.; Hayashibara, Y.; Inasaki, N.; Inahata, R.; Hasegawa, S.; Takizawa, T.; Kaya, H. A False Positive Dengue Fever Rapid Diagnostic Test Result in a Case of Acute Parvovirus B19 Infection. Intern. Med. 2016, 55, 1379-1382. [CrossRef] [PubMed]

247. Di Paola, N.; Mesquita, F.S.; Oliveira, D.B.L.; Villabona-Arenas, C.J.; Zaki Pour, S.; de Sousa-Capra, C.; Lopes, G.P.; Santana, R.A.F.; Pinho, J.R.R.; Balarini, K.; et al. An Outbreak of Human Parvovirus B19 Hidden by Dengue Fever. Clin. Infect. Dis. 2019, 68, 810-817. [CrossRef]

248. Oliveira, M.J.; Cordeiro, M.T.; Costa, F.M.; Murakami, G.; Silva, A.M.; Travassos, R.C.; Magalhaes, V. Frequency of measles, rubella, dengue and erythema infectiosum among suspected cases of measles and rubella in the State of Pernambuco between 2001 and 2004. Rev. Soc. Bras. Med. Trop. 2008, 41, 338-344. [CrossRef] [PubMed]

249. Freitas, R.B.; Melo, F.L.; Oliveira, D.S.; Romano, C.M.; Freitas, M.R.; Macedo, O.; Linhares, A.C.; Paolo, M.D.A.; Durigon, E.L. Molecular characterization of human erythrovirus B19 strains obtained from patients with several clinical presentations in the Amazon region of Brazil. J. Clin. Virol. 2008, 43, 60-65. [CrossRef]

250. Voordouw, B.; Rockx, B.; Jaenisch, T.; Fraaij, P.; Mayaud, P.; Vossen, A.; Koopmans, M. Performance of Zika Assays in the Context of Toxoplasma gondii, Parvovirus B19, Rubella Virus, and Cytomegalovirus (TORCH) Diagnostic Assays. Clin. Microbiol. Rev. 2019, 33, e00130-18. [CrossRef]

251. Leung, K.K.Y.; Hon, K.L.; Yeung, A.; Leung, A.K.C.; Man, E. Congenital infections in Hong Kong: An overview of TORCH. Hong Kong Med. J. 2020, 26, 127-138.

252. Calabrese, L.H.; Naides, S.J. Viral arthritis. Infect. Dis. Clin. N. Am. 2005, 19, 963-980. [CrossRef]

253. Muzumdar, S.; Rothe, M.J.; Grant-Kels, J.M. The rash with maculopapules and fever in children. Clin. Dermatol. 2019, 37, 119-128. [CrossRef]

254. Muzumdar, S.; Rothe, M.J.; Grant-Kels, J.M. The rash with maculopapules and fever in adults. Clin. Dermatol. 2019, 37, 109-118. [CrossRef]

255. Khrustalev, V.V.; Ermalovich, M.A.; Hubschen, J.M.; Khrustaleva, T.A. Transcription-associated mutational pressure in the Parvovirus B19 genome: Reactivated genomes contribute to the variability of viral populations. J. Theor. Biol. 2017, 435, 199-207. [CrossRef] [PubMed]

256. Muhlemann, B.; Margaryan, A.; Damgaard, P.B.; Allentoft, M.E.; Vinner, L.; Hansen, A.J.; Weber, A.; Bazaliiskii, V.I.; Molak, M.; Arneborg, J.; et al. Ancient human parvovirus B19 in Eurasia reveals its long-term association with humans. Proc. Natl. Acad. Sci. USA 2018, 115, 7557-7562. [CrossRef] [PubMed] 
257. Oliveira, M.I.; Namiyama, G.M.; Cabral, G.B.; Ferreira, J.L.; Taniwaki, N.; Afonso, A.M.S.; Lima, I.R.; Brigido, L.F.M. Isolation of infectious Zika virus from a urine sample cultured in SIRC cells from a patient suspected of having rubella virus. Rev. Inst. Med. Trop. Sao Paulo 2018, 60, e15. [CrossRef] [PubMed]

258. Fantinato, F.F.; Araujo, E.L.; Ribeiro, I.G.; Andrade, M.R.; Dantas, A.L.; Rios, J.M.; Silva, O.M.; Silva, M.D.; Nobrega, R.V.; Batista, D.A.; et al. Description of the first cases of Zika virus fever investigated in municipalities of the Brazilian Northeastern Region, 2015. Epidemiol. Serv. Saude 2016, 25, 683-690. [CrossRef] [PubMed]

259. Rosenstierne, M.W.; Schaltz-Buchholzer, F.; Bruzadelli, F.; Co, A.; Cardoso, P.; Jorgensen, C.S.; Michiels, J.; Heyndrickx, L.; Arien, K.K.; Fischer, T.K.; et al. Zika Virus IgG in Infants with Microcephaly, Guinea-Bissau, 2016. Emerg. Infect. Dis. 2018, 24, 948-950. [CrossRef] [PubMed]

260. Rebora, A.; Ciccarese, G.; Herzum, A.; Parodi, A.; Drago, F. Pityriasis rosea and other infectious eruptions during pregnancy: Possible life-threatening health conditions for the fetus. Clin. Dermatol. 2020, 38, 105-112. [CrossRef] [PubMed]

261. De Vries, L.S. Viral Infections and the Neonatal Brain. Semin. Pediatr. Neurol. 2019, 32, 100769. [CrossRef] [PubMed]

262. Luria, L.; Cardoza-Favarato, G. Human papillomavirus. In StatPearls; StatPearls Publishing: Treasure Island, FL, USA, 2020.

263. Leslie, S.W.; Sajjad, H.; Kumar, S. Genital warts. In StatPearls; StatPearls Publishing: Treasure Island, FL, USA, 2020.

264. Freitas, A.C.; Mariz, F.C.; Silva, M.A.; Jesus, A.L. Human papillomavirus vertical transmission: Review of current data. Clin. Infect. Dis. 2013, 56, 1451-1456. [CrossRef]

265. Giuliano, A.R.; Nyitray, A.G.; Kreimer, A.R.; Pierce Campbell, C.M.; Goodman, M.T.; Sudenga, S.L.; Monsonego, J.; Franceschi, S. EUROGIN 2014 roadmap: Differences in human papillomavirus infection natural history, transmission and human papillomavirus-related cancer incidence by gender and anatomic site of infection. Int. J. Cancer 2015, 136, 2752-2760. [CrossRef]

266. De Villiers, E.M.; Fauquet, C.; Broker, T.R.; Bernard, H.U.; zur Hausen, H. Classification of papillomaviruses. Virology 2004, 324, 17-27. [CrossRef] [PubMed]

267. Krump, N.A.; Liu, W.; You, J. Mechanisms of persistence by small DNA tumor viruses. Curr. Opin. Virol. 2018, 32, 71-79. [CrossRef]

268. Kalantari, M.; Villa, L.L.; Calleja-Macias, I.E.; Bernard, H.U. Human papillomavirus-16 and -18 in penile carcinomas: DNA methylation, chromosomal recombination and genomic variation. Int. J. Cancer 2008, 123, 1832-1840. [CrossRef] [PubMed]

269. Pett, M.; Coleman, N. Integration of high-risk human papillomavirus: A key event in cervical carcinogenesis? J. Pathol. 2007, 212, 356-367. [CrossRef] [PubMed]

270. Dillner, J.; Lenner, P.; Lehtinen, M.; Eklund, C.; Heino, P.; Wiklund, F.; Hallmans, G.; Stendahl, U. A population-based seroepidemiological study of cervical cancer. Cancer Res. 1994, 54, 134-141.

271. Koskimaa, H.M.; Paaso, A.; Welters, M.J.P.; Grenman, S.; Syrjanen, K.; van der Burg, S.H.; Syrjanen, S. The presence of human papillomavirus (HPV) in placenta and/or cord blood might result in Th2 polarization. Eur. J. Clin. Microbiol. Infect. Dis. 2017, 36, 1491-1503. [CrossRef]

272. Koskimaa, H.M.; Paaso, A.E.; Welters, M.J.; Grenman, S.E.; Syrjanen, K.J.; van der Burg, S.H.; Syrjanen, S.M. Human papillomavirus 16 E2-, E6- and E7-specific T-cell responses in children and their mothers who developed incident cervical intraepithelial neoplasia during a 14-year follow-up of the Finnish Family HPV cohort. J. Transl. Med. 2014, 12, 44. [CrossRef]

273. Armbruster-Moraes, E.; Ioshimoto, L.M.; Leao, E.; Zugaib, M. Prevalence of 'high risk' human papillomavirus in the lower genital tract of Brazilian gravidas. Int. J. Gynaecol. Obstet. 2000, 69, 223-227. [CrossRef]

274. Armbruster-Moraes, E.; Ioshimoto, L.M.; Leao, E.; Zugaib, M. Presence of human papillomavirus DNA in amniotic fluids of pregnant women with cervical lesions. Gynecol. Oncol. 1994, 54, 152-158. [CrossRef]

275. Armbruster-Moraes, E.; Ioshimoto, L.M.; Leao, E.; Zugaib, M. Possible prodromes of human papillomavirus uterine cervix infection. Int. J. Gynaecol. Obstet. 1993, 42, 269-271. [CrossRef]

276. Dealtry, G.B.; O'Farrell, M.K.; Fernandez, N. The Th2 cytokine environment of the placenta. Int. Arch. Allergy Immunol. 2000, 123, 107-119. [CrossRef]

277. Koskimaa, H.M.; Paaso, A.; Welters, M.J.; Grenman, S.; Syrjanen, K.; van der Burg, S.H.; Syrjanen, S. Human papillomavirus 16-specific cell-mediated immunity in children born to mothers with incident cervical intraepithelial neoplasia (CIN) and to those constantly HPV negative. J. Transl. Med. 2015, 13, 370. [CrossRef]

278. Amirian, E.S.; Adler-Storthz, K.; Scheurer, M.E. Associations between human herpesvirus-6, human papillomavirus and cervical cancer. Cancer Lett. 2013, 336, 18-23. [CrossRef]

279. Zhao, Y.; Cao, X.; Tang, J.; Zhou, L.; Gao, Y.; Wang, J.; Zheng, Y.; Yin, S.; Wang, Y. A novel multiplex real-time PCR assay for the detection and quantification of HPV16/18 and HSV1/2 in cervical cancer screening. Mol. Cell. Probes 2012, 26, 66-72. [CrossRef] [PubMed]

280. Zhao, Y.; Cao, X.; Zheng, Y.; Tang, J.; Cai, W.; Wang, H.; Gao, Y.; Wang, Y. Relationship between cervical disease and infection with human papillomavirus types 16 and 18, and herpes simplex virus 1 and 2. J. Med. Virol. 2012, 84, 1920-1927. [CrossRef]

281. Meyrelles, A.R.I.; Siqueira, J.D.; Hofer, C.B.; Costa, T.P.; Azevedo, A.P.; Guimaraes, B.V.; Seuanez, H.N.; Soares, M.A.; Almeida, G.; Soares, E.A.; et al. HIV/HPV co-infection during pregnancy in southeastern Brazil: Prevalence, HPV types, cytological abnormalities and risk factors. Gynecol. Oncol. 2013, 128, 107-112. [CrossRef] [PubMed]

282. Miranda, A.E.; Silveira, M.F.; Travassos, A.G.; Tenorio, T.; Val, I.C.C.; Lannoy, L.; Mattos Junior, H.S.; Carvalho, N.S. High-risk papillomavirus infection among women living with human Immunodeficiency virus: Brazilian multicentric study. J. Med. Virol. 2017, 89, 2217-2223. [CrossRef] [PubMed] 
283. Tornatore, M.; Goncalves, C.V.; Bianchi, M.S.; Germano, F.N.; Garces, A.X.; Soares, M.A.; Machado, E.S.; de Martinez, A.M. Co-infections associated with human immunodeficiency virus type 1 in pregnant women from southern Brazil: High rate of intraepithelial cervical lesions. Mem. Inst. Oswaldo Cruz 2012, 107, 205-210. [CrossRef]

284. Ambuhl, L.M.M.; Leonhard, A.K.; Widen Zakhary, C.; Jorgensen, A.; Blaakaer, J.; Dybkaer, K.; Baandrup, U.; Uldbjerg, N.; Sorensen, S. Human papillomavirus infects placental trophoblast and Hofbauer cells, but appears not to play a causal role in miscarriage and preterm labor. Acta Obstet. Gynecol. Scand. 2017, 96, 1188-1196. [CrossRef]

285. Ambuhl, L.M.M.; Villadsen, A.B.; Baandrup, U.; Dybkaer, K.; Sorensen, S. HPV16 E6 and E7 Upregulate Interferon-Induced Antiviral Response Genes ISG15 and IFIT1 in Human Trophoblast Cells. Pathogens 2017, 6, 40. [CrossRef]

286. Lebov, J.F.; Arias, J.F.; Balmaseda, A.; Britt, W.; Cordero, J.F.; Galvao, L.A.; Garces, A.L.; Hambidge, K.M.; Harris, E.; Ko, A.; et al. Correction to: International prospective observational cohort study of Zika in infants and pregnancy (ZIP study): Study protocol. BMC Pregnancy Childbirth 2019, 19, 423. [CrossRef]

287. Correa, C.M.; Teixeira, N.C.; Araujo, A.C.; Carvalho Nde, O.; Castillo, D.M.; Campos, R.R.; Oliveira, I.V.; Alves, A.R.; Franca, A.F.; Melo, V.H. Prevalence and multiplicity of HPV in HIV women in Minas Gerais, Brazil. Rev. Assoc. Med. Bras. (1992) 2011, 57, 425-430. [CrossRef] [PubMed]

288. Cambou, M.C.; Luz, P.M.; Lake, J.E.; Levi, J.E.; Coutinho, J.R.; de Andrade, A.; Heinke, T.; Derrico, M.; Veloso, V.G.; Friedman, R.K.; et al. Anal human papillomavirus (HPV) prevalences and factors associated with abnormal anal cytology in HIV-infected women in an urban cohort from Rio de Janeiro, Brazil. AIDS Patient Care STDS 2015, 29, 4-12. [CrossRef] [PubMed]

289. Cambou, M.C.; Levi, J.E.; Lake, J.E.; de Andrade, A.; Jalil, E.M.; Russomano, F.; Derrico, M.; Veloso, V.G.; Friedman, R.K.; Luz, P.M.; et al. Time trend analysis of cervical high-risk human papillomavirus (HPV) in HIV-infected women in an urban cohort from Rio de Janeiro, Brazil: The rise of non-16/18 HPV. Int. J. Infect. Dis. 2015, 41, 17-20. [CrossRef]

290. Freitas, T.P.; Carmo, B.B.; Paula, F.D.; Rodrigues, L.F.; Fernandes, A.P.; Fernandes, P.A. Molecular detection of HPV 16 and 18 in cervical samples of patients from Belo Horizonte, Minas Gerais, Brazil. Rev. Inst. Med. Trop. Sao Paulo 2007, 49, $297-301$. [CrossRef]

291. Vieira, M.; Castro, A.A.S.; Henriques, D.F.; Silva, E.; Tavares, F.N.; Martins, L.C.; Guimaraes, L.M.; Monteiro, T.A.F.; Azevedo, R.; Cruz, A.C.R.; et al. Encephalitis associated with Zika virus infection and reactivation of the varicella-zoster virus in a Brazilian child. Rev. Soc. Bras. Med. Trop. 2018, 51, 390-392. [CrossRef]

292. Joob, B.; Wiwanitkit, V. Zika virus, HSV-2 and placenta. Am. J. Reprod. Immunol. 2017, 77, e12603. [CrossRef]

293. Moreira-Soto, A.; Carneiro, I.O.; Fischer, C.; Feldmann, M.; Kummerer, B.M.; Silva, N.S.; Santos, U.G.; Souza, B.; Liborio, F.A.; Valenca-Montenegro, M.M.; et al. Limited Evidence for Infection of Urban and Peri-urban Nonhuman Primates with Zika and Chikungunya Viruses in Brazil. mSphere 2018, 3, e00523-17. [CrossRef]

294. Rodriguez-Morales, A.J. Zika and microcephaly in Latin America: An emerging threat for pregnant travelers? Travel. Med. Infect. Dis. 2016, 14, 5-6. [CrossRef]

295. Grobusch, M.P.; Karimi, O.; Schinkel, J.; Codrington, J.; Vreden, S.G.; Vermaat, J.S.; Stijnis, C.; Goorhuis, A. Uncommon presentation of Zika fever or co-infection?-Authors' reply. Lancet 2016, 387, 1813-1814. [CrossRef]

296. Alvarado-Socarras, J.L.; Rodriguez-Morales, A.J. Etiological agents of microcephaly: Implications for diagnosis during the current Zika virus epidemic. Ultrasound Obstet. Gynecol. 2016, 47, 525-526. [CrossRef] [PubMed]

297. Al-Buhtori, M.; Moore, L.; Benbow, E.W.; Cooper, R.J. Viral detection in hydrops fetalis, spontaneous abortion, and unexplained fetal death in utero. J. Med. Virol. 2011, 83, 679-684. [CrossRef] [PubMed]

298. White, M.K.; Khalili, K. CRISPR/Cas9 and cancer targets: Future possibilities and present challenges. Oncotarget 2016, 7, 12305-12317. [CrossRef]

299. Hill, J.M.; Quenelle, D.C.; Cardin, R.D.; Vogel, J.L.; Clement, C.; Bravo, F.J.; Foster, T.P.; Bosch-Marce, M.; Raja, P.; Lee, J.S.; et al. Inhibition of LSD1 reduces herpesvirus infection, shedding, and recurrence by promoting epigenetic suppression of viral genomes. Sci. Transl. Med. 2014, 6, 265ra169. [CrossRef] [PubMed]

300. Liang, Y.; Vogel, J.L.; Narayanan, A.; Peng, H.; Kristie, T.M. Inhibition of the histone demethylase LSD1 blocks alpha-herpesvirus lytic replication and reactivation from latency. Nat. Med. 2009, 15, 1312-1317. [CrossRef] [PubMed]

301. Shirakawa, T.; Yaman-Deveci, R.; Tomizawa, S.; Kamizato, Y.; Nakajima, K.; Sone, H.; Sato, Y.; Sharif, J.; Yamashita, A.; TakadaHorisawa, Y.; et al. An epigenetic switch is crucial for spermatogonia to exit the undifferentiated state toward a Kit-positive identity. Development 2013, 140, 3565-3576. [CrossRef] [PubMed]

302. D'Aiuto, L.; Williamson, K.; Dimitrion, P.; McNulty, J.; Brown, C.E.; Dokuburra, C.B.; Nielsen, A.J.; Lin, W.J.; Piazza, P.; Schurdak, M.E.; et al. Comparison of three cell-based drug screening platforms for HSV-1 infection. Antivir. Res. 2017, 142, 136-140. [CrossRef] [PubMed]

303. Ribeiro, G.S.; Hamer, G.L.; Diallo, M.; Kitron, U.; Ko, A.I.; Weaver, S.C. Influence of herd immunity in the cyclical nature of arboviruses. Curr. Opin. Virol. 2020, 40, 1-10. [CrossRef] [PubMed]

304. Pedroso, C.; Fischer, C.; Feldmann, M.; Sarno, M.; Luz, E.; Moreira-Soto, A.; Cabral, R.; Netto, E.M.; Brites, C.; Kummerer, B.M.; et al. Cross-Protection of Dengue Virus Infection against Congenital Zika Syndrome, Northeastern Brazil. Emerg. Infect. Dis. 2019, 25, 1485-1493. [CrossRef]

305. Carvalho, F.R.; Medeiros, T.; Vianna, R.A.O.; Douglass-Jaimes, G.; Nunes, P.C.G.; Quintans, M.D.S.; Souza, C.F.; Cavalcanti, S.M.B.; Dos Santos, F.B.; Oliveira, S.A.; et al. Simultaneous circulation of arboviruses and other congenital infections in pregnant women in Rio de Janeiro, Brazil. Acta Trop. 2019, 192, 49-54. [CrossRef] [PubMed] 
306. Ali, M.; Miller, K.; Gomez Ponce de Leon, R.F. Family planning and Zika virus: Need for renewed and cohesive efforts to ensure availability of intrauterine contraception in Latin America and the Caribbean. Eur. J. Contracept. Reprod. Health Care 2017, 22, 102-106. [CrossRef] [PubMed]

307. Poole, E.; Huang, C.J.Z.; Forbester, J.; Shnayder, M.; Nachshon, A.; Kweider, B.; Basaj, A.; Smith, D.; Jackson, S.E.; Liu, B.; et al. An iPSC-Derived Myeloid Lineage Model of Herpes Virus Latency and Reactivation. Front. Microbiol. 2019, 10, 2233. [CrossRef] [PubMed]

308. Wilcox, C.L.; Smith, R.L. HSV Latency In Vitro: In Situ Hybridization Methods. Methods Mol. Med. 1998, 10, 317-326. [PubMed]

309. Sobhani, N.C.; Avvad-Portari, E.; Nascimento, A.C.M.; Machado, H.N.; Lobato, D.S.S.; Pereira, J.P.; Esquivel, M.S.; Vasconcelos, Z.C.; Zin, A.A.; Tsui, I.; et al. Discordant Zika Virus Findings in Twin Pregnancies Complicated by Antenatal Zika Virus Exposure: A Prospective Cohort. J. Infect. Dis. 2020, 221, 1838-1845. [CrossRef] [PubMed]

310. Byers, N.M.; Fleshman, A.C.; Perera, R.; Molins, C.R. Metabolomic Insights into Human Arboviral Infections: Dengue, Chikungunya, and Zika Viruses. Viruses 2019, 11, 225. [CrossRef] [PubMed] 